\title{
Reactive Oxygen Species and Antioxidant Defense in Plants under Abiotic Stress: Revisiting the Crucial Role of a Universal Defense Regulator
}

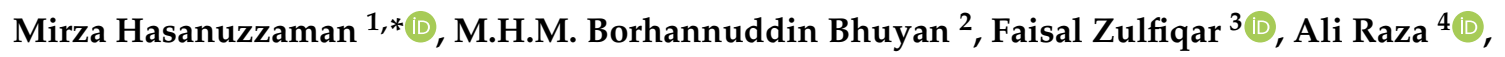 \\ Sayed Mohammad Mohsin ${ }^{5,6}{ }^{\mathbb{D}}$, Jubayer Al Mahmud ${ }^{7}$, Masayuki Fujita ${ }^{5}$ and \\ Vasileios Fotopoulos $8, *$ (D) \\ 1 Department of Agronomy, Faculty of Agriculture, Sher-e-Bangla Agricultural University, \\ Sher-e-Bangla Nagar, Dhaka 1207, Bangladesh \\ 2 Citrus Research Station, Bangladesh Agricultural Research Institute, Jaintapur, Sylhet 3156, Bangladesh; \\ mhmb_bhuyan@bari.gov.bd \\ 3 Institute of Horticultural Sciences, Faculty of Agriculture, University of Agriculture Faisalabad, \\ Faisalabad 38000, Pakistan; ch.faisal.zulfiqar@gmail.com \\ 4 Key Lab of Biology and Genetic Improvement of Oil Crops, Oil Crops Research Institute, Chinese Academy \\ of Agricultural Sciences (CAAS), Wuhan 430062, China; alirazamughal143@gmail.com \\ 5 Laboratory of Plant Stress Response, Faculty of Agriculture, Kagawa University, Miki-cho, Kita-Gun, \\ Kagawa 761-0795, Japan; mohsin@sau.edu.bd (S.M.M.); fujita@ag.kagawa-u.ac.jp (M.F.) \\ 6 Department of Plant Pathology, Faculty of Agriculture, Sher-e-Bangla Agricultural University, \\ Sher-e-Bangla Nagar, Dhaka 1207, Bangladesh \\ 7 Department of Agroforestry and Environmental Science, Faculty of Agriculture, Sher-e-Bangla Agricultural \\ University, Sher-e-Bangla Nagar, Dhaka 1207, Bangladesh; jamahmud_bd@yahoo.com \\ 8 Department of Agricultural Sciences, Biotechnology \& Food Science, Cyprus University of Technology, \\ P.O. Box 50329, Lemesos 3603, Cyprus \\ * Correspondence: mhzsauag@yahoo.com or mirzahasanuzzaman@sau.edu.bd (M.H.); \\ vassilis.fotopoulos@cut.ac.cy (V.F.)
}

Received: 24 June 2020; Accepted: 27 July 2020; Published: 29 July 2020

\begin{abstract}
Global climate change and associated adverse abiotic stress conditions, such as drought, salinity, heavy metals, waterlogging, extreme temperatures, oxygen deprivation, etc., greatly influence plant growth and development, ultimately affecting crop yield and quality, as well as agricultural sustainability in general. Plant cells produce oxygen radicals and their derivatives, so-called reactive oxygen species (ROS), during various processes associated with abiotic stress. Moreover, the generation of ROS is a fundamental process in higher plants and employs to transmit cellular signaling information in response to the changing environmental conditions. One of the most crucial consequences of abiotic stress is the disturbance of the equilibrium between the generation of ROS and antioxidant defense systems triggering the excessive accumulation of ROS and inducing oxidative stress in plants. Notably, the equilibrium between the detoxification and generation of ROS is maintained by both enzymatic and nonenzymatic antioxidant defense systems under harsh environmental stresses. Although this field of research has attracted massive interest, it largely remains unexplored, and our understanding of ROS signaling remains poorly understood. In this review, we have documented the recent advancement illustrating the harmful effects of ROS, antioxidant defense system involved in ROS detoxification under different abiotic stresses, and molecular cross-talk with other important signal molecules such as reactive nitrogen, sulfur, and carbonyl species. In addition, state-of-the-art molecular approaches of ROS-mediated improvement in plant antioxidant defense during the acclimation process against abiotic stresses have also been discussed.
\end{abstract}


Keywords: abiotic stress; antioxidant systems; ascorbate-glutathione pathway; cross tolerance; $\mathrm{H}_{2} \mathrm{O}_{2}$; oxidative stress; plant stress tolerance; reactive nitrogen species; reactive oxygen species; stress signaling

\section{Introduction}

Environmental stresses, including salinity, drought, extreme temperature, toxic metals/metalloids, flooding/waterlogging (WL), etc. are now prevalent due to drastic and harsh climate change [1,2]. The aggravation of such diverse abiotic stresses has become a major threat to sustainable crop production. Alongside, numerous detrimental effects lead to oxidative stress through the overaccumulation of reactive oxygen species (ROS) including free radicals (superoxide anion, $\mathrm{O}_{2}{ }^{\bullet-}$; hydroperoxyl radical, $\mathrm{HO}_{2}{ }^{\bullet}$; alkoxy radical, $\mathrm{RO}^{\bullet}$; and hydroxyl radical, ${ }^{\bullet} \mathrm{OH}$ ) and nonradical molecules (hydrogen peroxide, $\mathrm{H}_{2} \mathrm{O}_{2}$ and singlet oxygen, $\left.{ }^{1} \mathrm{O}_{2}\right)[3,4]$. High-energy initiation or electron transfer reactions lead to atmospheric oxygen $\left(\mathrm{O}_{2}\right)$ to the abovementioned partially reduced or activated forms of molecular oxygen [5]. The primary cellular ROS generation sites are chloroplasts, mitochondria, peroxisomes, apoplast, and plasma membranes [6]. Although ROS are formed in the plant as part of normal cellular metabolism, overaccumulation due to stress severely damages necessary cellular ingredients including carbohydrates, proteins, lipids, DNA, etc. because of their highly reactive nature [7].

Plants primarily deal with oxidative stress via an endogenous defensive mechanism consisting of different enzymatic (superoxide dismutase, SOD; catalase, CAT; ascorbate peroxidase, APX; glutathione reductase, GR; monodehydroascorbate reductase, MDHAR; dehydroascorbate reductase, DHAR; glutathione peroxidase, GPX; guaiacol peroxidase, GOPX; glutathione S-transferase, GST; Ferritin; nicotinamide adenine dinucleotide phosphate (NADPH) oxidase-like alternative oxidase, AOX; peroxiredoxins, PRXs; thioredoxins, TRXs; glutaredoxin, GRX; etc.) and nonenzymatic (ascorbic acid, AsA; glutathione, GSH; phenolic acids; alkaloids; flavonoids; carotenoids; $\alpha$-tocopherol; nonprotein amino acids; etc.) antioxidants [8-10]. In plant cells, the antioxidant defense system and ROS accumulation uphold a steady-state balance [9]. Maintaining an optimum ROS level in the cell enables proper redox biology reactions and the regulation of numerous processes essential for plants such as growth and development [11]. This intermediate level is maintained by the balance between ROS production and ROS scavenging [4]. However, during stress conditions, overgeneration of ROS demolishes the equilibrium and causes cellular damage, leading to programmed cell death (PCD) as well as decreasing plant productivity [7].

Besides their damaging activity, ROS are well known as secondary messengers or signaling molecules and transport the signal to the nucleus through redox reactions using mitogen-activated protein kinase (MAPK) pathway in a variety of cellular mechanisms to increase tolerance against diverse abiotic stresses [6]. Reactive oxygen species participate as major molecules in the acclimation process of plants under environmental stimuli. They principally act as signal transduction molecules, which control diverse pathways throughout the acclimation of the plant under stress conditions $[5,12]$. Several studies showed that ROS are essential for the success of numerous fundamental natural processes, including cellular proliferation and differentiation [11]. In addition, $\mathrm{H}_{2} \mathrm{O}_{2}$ is a critical component of stress response regulation in crop plants such as rice [13], wheat [14], maize [15], mung bean [16], soybean [17], cucumber [18], sour orange [19], strawberry [20], basil [21], and rapeseed [22]. Moreover, it is established that in addition to ROS, reactive nitrogen species (RNS), reactive sulfur species (RSS), and reactive carbonyl species (RCS) also play a key signaling role and are all involved in a cross-talk in plant abiotic stress tolerance [23]. Therefore, ROS play a crucial, dual role in plant biology, representing a fascinating area of research for plant biologists.

In this review, we summarize the recent progress of harmful effects of ROS, antioxidant defense system involved in ROS detoxification under different abiotic stresses, and also the cross-talk of 
RNS, RSS, and RCS with ROS. We also focus on progress in molecular approaches of ROS-mediated improvement in plant antioxidant defense during the acclimation process against abiotic stress.

\section{Chemistry of Reactive Oxygen Species}

Atmospheric $\mathrm{O}_{2}$ is a free molecule that exists in the ground state (triplet oxygen, ${ }^{3} \mathrm{O}_{2}$ ) having two unpaired parallel spin electrons with the same spin numbers, which drop off its reactivity. However, additional energy from some biochemical reactions, electron transport chains (ETC), ultraviolet- $\mathrm{B}$, and ionizing irradiations assist ${ }^{3} \mathrm{O}_{2}$ to get rid of the spin restriction and thus becoming ROS (Figure 1) [24].

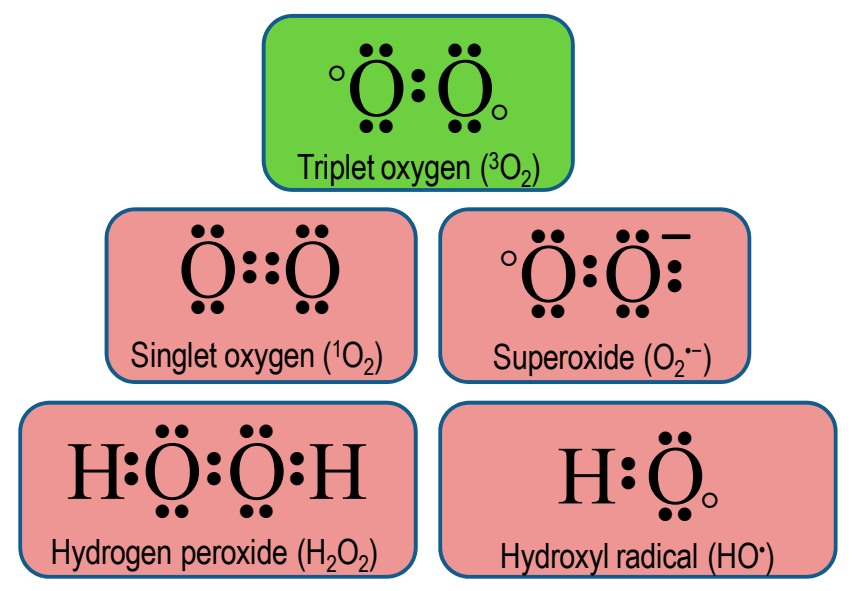

Figure 1. Lewis dot structure of triplet oxygen and reactive oxygen species.

In plant cells, ROS can be formed in many compartments including chloroplasts, mitochondria, peroxisomes, and plasma membrane [25]. In the chloroplast, the chlorophyll (chl) pigments absorb light quanta and become excited to their triplet state. If this triplet chl is not quenched efficiently, a charge recombination occurs leading ${ }^{3} \mathrm{O}_{2}$ to excited ${ }^{1} \mathrm{O}_{2}$ [25]. Although its lifetime is very short (3.1-3.9 $\mu \mathrm{s})$ and diffusion distance is low $(190 \mathrm{~nm}),{ }^{1} \mathrm{O}_{2}$ diffuses outside the chloroplast to reach the cell wall, targets plasma membrane, tonoplast, or even cytosolic signaling cascades [26]. Furthermore, ${ }^{3} \mathrm{O}_{2}$ can receive electrons from ETC or nicotinamide adenine dinucleotide phosphate (NADPH) oxidase activity producing $\mathrm{O}_{2}{ }^{\bullet-}$, which has a half-life of 1-1000 $\mu$ s [4]. In addition, $\mathrm{O}_{2}{ }^{\bullet-}$ reacts with $\mathrm{H}^{+}$ producing $\mathrm{HO}_{2}{ }^{\bullet-}$, which is far more reactive, stable, and permeable through biological membranes. Similarly, $\mathrm{H}_{2} \mathrm{O}_{2}$ can be produced through the dismutation of $\mathrm{O}_{2}{ }^{\bullet-} / \mathrm{HO}_{2}{ }^{\bullet-}$ by SOD isoforms, NADPH oxidases, and heme-containing class III peroxidases (POX) activity [27,28]. Chemically, $\mathrm{H}_{2} \mathrm{O}_{2}$ acts as a weak acid that is highly diffusible and stable, having a lifetime of $<1 \mathrm{~s}$, and could cross the plasma membrane via aquaporins [29]. Another important $\mathrm{ROS}-{ }^{\bullet} \mathrm{OH}$, can be produced by the Fenton reaction, hydroperoxides activity during sunlight, and inner-sphere electron transfer. Moreover, specific proteins, such as heme oxygenases, cytochrome P450s, superoxide reductases, and some photosystem II (PSII) proteins, also generate $\bullet^{\bullet} \mathrm{OH}$ [30]. The computed half-life of $\bullet^{\mathrm{HO}}$ is approximately $1 \mathrm{~ns}$ and has a short diffusibility $(<1 \mathrm{~nm})$.

Some reactions of production and conversions of ROS in the biological system:

$$
\begin{gathered}
\mathrm{O}_{2}+\mathrm{e}^{-} \rightarrow \mathrm{O}_{2}^{\bullet-} \\
\mathrm{O}_{2}^{\bullet-}+\mathrm{H}^{+} \rightleftarrows \mathrm{HO}_{2}^{\bullet-} \\
\mathrm{H}_{2} \mathrm{O}_{2}+\mathrm{HO}^{\bullet} \rightleftarrows \mathrm{HO}_{2}^{\bullet-}+\mathrm{H}_{2} \mathrm{O} \\
\bullet \mathrm{OH}+\bullet \mathrm{OH} \rightleftarrows \mathrm{O}^{\bullet}+\mathrm{H}_{2} \mathrm{O}
\end{gathered}
$$




$$
\begin{gathered}
\mathrm{O}_{2}^{\bullet-}+2 \mathrm{H}^{+}+\mathrm{e}^{-} \rightarrow \mathrm{H}_{2} \mathrm{O}_{2} \\
\mathrm{O}_{2}^{\bullet-}+\mathrm{HO}_{2}{ }^{\bullet-}+\mathrm{H}_{2} \mathrm{O} \rightarrow \mathrm{H}_{2} \mathrm{O}_{2}+\mathrm{O}_{2}+{ }^{\bullet} \mathrm{OH} \\
\mathrm{HOOH} \rightarrow \mathrm{HO}{ }^{\bullet} \cdot \mathrm{OH} \\
\mathrm{ROOH} \rightarrow \mathrm{RH}^{\bullet}+\bullet \\
{ }^{\bullet} \mathrm{OH} \\
\mathrm{Fe}^{3+} / \mathrm{Cu}^{2+} / \mathrm{Mn}^{3+}+\mathrm{H}_{2} \mathrm{O}_{2} \rightarrow \mathrm{Fe}^{2+} / \mathrm{Cu}^{+} / \mathrm{Mn}^{2+} \mathrm{OH}+{ }^{\bullet} \mathrm{OH} \\
\mathrm{Fe}^{2+} / \mathrm{Cu}^{+} / \mathrm{Mn}^{2+}+\mathrm{H}_{2} \mathrm{O}_{2} \rightarrow \mathrm{Fe}^{3+} / \mathrm{Cu}^{2+} / \mathrm{Mn}^{3+}+\mathrm{HO}_{2}^{\bullet-}+\mathrm{H}^{+}
\end{gathered}
$$

Cellular ROS are comprised of both free radical and nonradicals (Figure 2). Among the free radicals, $\mathrm{O}_{2}{ }^{\bullet-},{ }^{\bullet} \mathrm{OH}, \mathrm{RO}^{\bullet}$, and peroxyl radical $(\mathrm{ROO})^{\bullet}$ ) and nonradicals, $\mathrm{H}_{2} \mathrm{O}_{2},{ }^{1} \mathrm{O}_{2}$, and ozone $\left(\mathrm{O}_{3}\right)$ are common [31]. However, some other nonradical ROS are also found in plants such as hypochlorous acid $(\mathrm{HOCl})$, hydroperoxides $(\mathrm{ROOH})$, and excited carbonyls $\left(\mathrm{RO}^{*}\right)$ [32]. Moreover, reactive oxygen intermediates (ROI) are also classified as reactive oxygen molecules formed by incomplete reduction of $\mathrm{O}_{2}$; therefore, ROS include all types of ROI as well as $\mathrm{O}_{3}$ and ${ }^{1} \mathrm{O}_{2}$. In addition, some acids like hypobromous acid (HOBr), hypoiodous acid (HOI), and $\mathrm{HOCl}$ and radicals like carbonate radical $\left(\mathrm{CO}_{3}{ }^{\bullet-}\right)$ and semiquinone $\left(\mathrm{SQ}^{\bullet-}\right)$ are also incorporated into ROS [33-35].

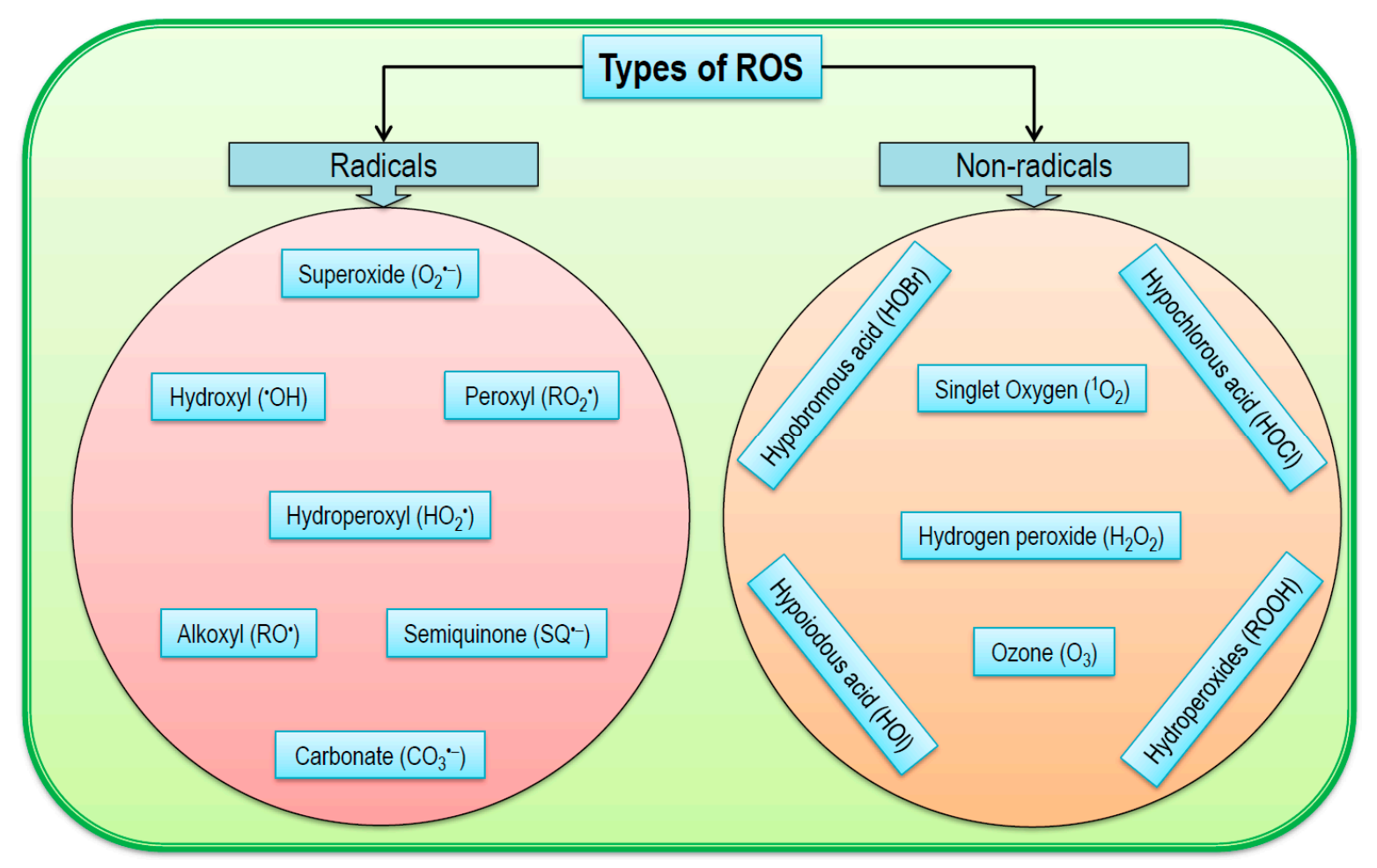

Figure 2. Types of reactive oxygen species in plants.

Among $\mathrm{ROS}, \mathrm{O}_{2}{ }^{\bullet-}$ predominantly acts as a reducing agent forming strong oxidants. Moreover, $\mathrm{O}_{2}{ }^{\bullet-}$ reacts with nitric oxide (NO) producing RNSs, RSSs, and RCSs. These compounds also promote oxidative stress, and are involved in "shaping" the intra- and extracellular redox signal [36,37].

\section{Localization and Processes of the Generation of ROS in Plant Cells}

In plant cells, chloroplasts, mitochondria, peroxisomes, plasma membrane, and cell wall are the major locations of ROS generation [38,39]. Therefore, compartmental ROS generation amounts to its overall production in plants (Figure 3) [6,40]. 


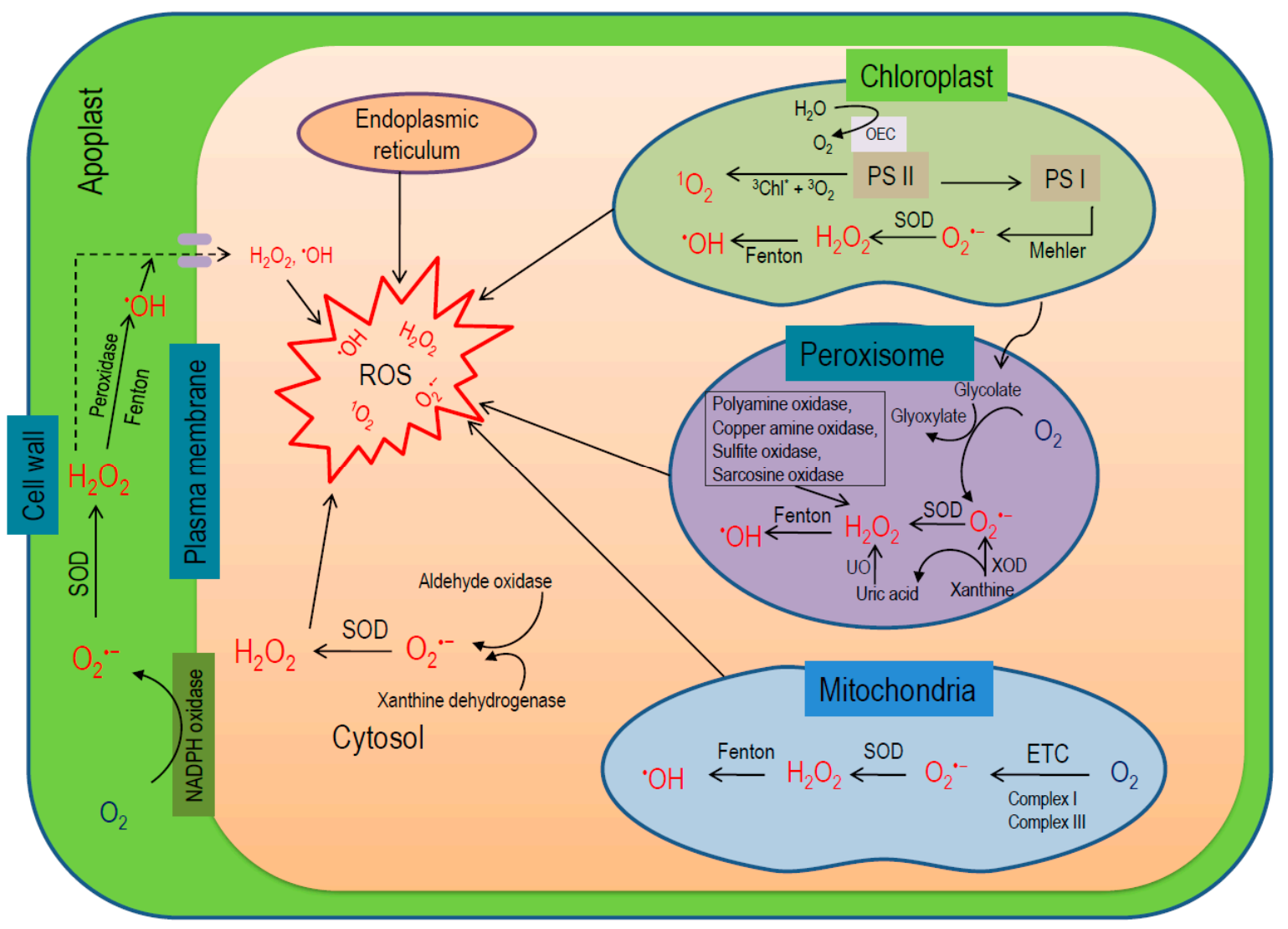

Figure 3. Localization and processes for the generation of ROS in plant cells (ROS, reactive oxygen species; $\mathrm{H}_{2} \mathrm{O}_{2}$, hydrogen peroxide; $\mathrm{O}_{2}{ }^{\bullet-}$, superoxide anion; ${ }^{1} \mathrm{O}_{2}$, singlet oxygen; ${ }^{\bullet} \mathrm{OH}$, hydroxyl radical; $\mathrm{SOD}$, superoxide dismutase; UO, urate oxidase; $\mathrm{XOD}$, xanthine oxidase; ETC, electron transport chain; PS I, photosystem I; PS II, photosystem II; NADPH, nicotinamide adenine dinucleotide phosphate).

Chloroplasts are the prime sites for ROS production (30-100 times higher than mitochondria), depending on the interaction of chl and light, where triplet chl and ETC of PS I and II are the main sources of ROS production [6,40,41]. In PS II under illumination, chl in light harvesting complex (PSII-LHC) becomes excited to high-energy singlet state $\left({ }^{1} \mathrm{Chl}^{*}\right.$; short-lived, $\sim 10^{-8} \mathrm{~s}$ ). A portion of this energy is transferred to P680 by photochemical quenching ( $\mathrm{pQ}$ ) for driving the photosynthetic ETC. However, if the absorbed energy exceeds the $\mathrm{pQ}$ capacity, the excess energy is dissipated as heat or fluorescence or via intersystem crossing forming ${ }^{3} \mathrm{Chl}^{*}$ (lower energy; longer half-life, $\sim 10^{-3} \mathrm{~s}$ ) [42]. The carotenoids present in the LHC (lutein and zeaxanthin) quench ${ }^{3} \mathrm{Chl}^{*}$ preventing transfer of energy to other molecules. If this ${ }^{3} \mathrm{Chl}^{*}$ is not efficiently quenched, it reacts with ${ }^{3} \mathrm{O}_{2}$ released from splitting of $\mathrm{H}_{2} \mathrm{O}$ in oxygen-evolving complex (OEC) leading to the formation of ${ }^{1} \mathrm{O}_{2}$ [43]. Moreover, in the PSII reaction center (RC), P680 absorbs light energy and becomes excited to singlet state $\left({ }^{1} \mathrm{P} 680^{*}\right)$ pairing with pheophytin (Pheo), ${ }^{1}\left(\mathrm{P} 680{ }^{+} \mathrm{Pheo}^{-}\right)$and later, transfers an electron to the quinone $\left(\mathrm{Q}_{\mathrm{A}}\right)$, forming $\mathrm{P}_{680}{ }^{+} \mathrm{Q}_{\mathrm{A}}{ }^{-}$. In an adverse situation, if $\mathrm{Q}_{\mathrm{A}}$ is previously reduced thus being unable to accept any further electrons, ${ }^{3}\left(\mathrm{P} 680{ }^{+} \mathrm{PheO}^{-}\right)$recombines with $\mathrm{P} 680$ forming an excited state ${ }^{3} \mathrm{P} 680^{*}$ [44]. In the PSII RC, two molecules of $\beta$-carotene are present, which are capable of quenching this high-energy ${ }^{3} \mathrm{P} 680^{*}$, but the distance between them is too large (more than the Van der Waal's distance of $3.6 \AA$ ) and quenching remains unsuccessful leading to generation of ${ }^{1} \mathrm{O}_{2}$ [45]. In addition, some abiotic stresses causing stomatal closure drop chloroplastic carbon dioxide $\left(\mathrm{CO}_{2}\right)$ levels leading to overreduction of the ETC and enhance the probability of charge recombination between ${ }^{1} \mathrm{P} 680^{*}$ and $\mathrm{Q}_{\mathrm{A}}{ }^{-}$in PS II, increasing ${ }^{1} \mathrm{O}_{2}$ production [46]. On the other hand, ${ }^{1} \mathrm{O}_{2}$ is not produced at PS I [47], instead, $\mathrm{O}_{2}{ }^{\bullet-}$ can be produced by Mehler reaction and later converted into $\mathrm{H}_{2} \mathrm{O}_{2}$ by SOD [48]. Later on, metal ions 
such as $\mathrm{Fe}^{2+}$ converts both $\mathrm{O}_{2}{ }^{\bullet-}$ and $\mathrm{H}_{2} \mathrm{O}_{2}$ to highly stable ${ }^{\bullet} \mathrm{OH}$ [6]. In the nongreen plant parts, especially in roots, mitochondria are the main source of ROS production, where electron leakage from both complex I and III of ETC produces $\mathrm{O}_{2}{ }^{\bullet-}$, which later catalyzed into $\mathrm{H}_{2} \mathrm{O}_{2}$ by Mn-SOD and CuZn-SOD [6,48]. In peroxisomes, glycolate oxidase (GOX) is the main source of ROS production [49]. Moreover, xanthine oxidase (XOD) activity can produce $\mathrm{O}_{2}{ }^{\bullet-}$ and uric acid in peroxisomal matrix, which further dismutates to $\mathrm{H}_{2} \mathrm{O}_{2}$ by SOD and urate oxidase (UO), respectively [50-52]. Besides $\beta$-oxidation of fatty acids, $\mathrm{O}_{2}{ }^{\bullet-}$ disproportionation and flavin oxidase activity could also produce $\mathrm{H}_{2} \mathrm{O}_{2}$ in peroxisomes [49,53]. In addition, polyamine oxidase, copper amine oxidase, sulfite oxidase, and sarcosine oxidase enzyme activity also can generate $\mathrm{H}_{2} \mathrm{O}_{2}$ in peroxisome [54]. However, the enzyme MDHAR has been demonstrated in peroxisomes, which helps to scavenge $\mathrm{H}_{2} \mathrm{O}_{2}$ by AsA-GSH cycle and regenerate AsA [55,56]. In the apoplast, NADPH oxidase, class III POX, amine and germin-like oxalate oxidases, quinine reductase, and lipoxygenases (LOX) contribute in ROS generation [11,57]. In the cell wall, POX, amine oxidases, and LOX activity are the potential source for ROS in the cell wall $[7,58]$. Furthermore, NADPH oxidase and quinone reductase guided the ROS production in the plasma membrane [58,59]. Apart from these prime sites, cytochrome (Cyt) $\mathrm{P} 450$ produces $\mathrm{O}_{2}{ }^{\bullet-}$ in the endoplasmic reticulum. In this process, a radical intermediate (Cyt P450R-) is formed first by the reaction between Cyt P450 and organic substrate $(\mathrm{RH})$ reduced by a flavoprotein. The resulted intermediate further reacts with ${ }^{3} \mathrm{O}_{2}$ forming a radical oxygenated complex Cyt $\mathrm{P} 450-\mathrm{ROO}^{-}$, which is finally reduced by Cyt $\mathrm{b}$ or spontaneously decomposed to release $\mathrm{O}_{2}{ }^{\bullet-}$ [58]. Fatty acid oxidation, as well as GOX and $\mathrm{UO}$ activities, produce $\mathrm{O}_{2}{ }^{\bullet-}$ and $\mathrm{H}_{2} \mathrm{O}_{2}$ in glyoxysomes [60]. Moreover, both XOD and aldehyde oxidase (AO) are potentially involved in cytosolic ROS production [61].

\section{Oxidative Stress in Plants and Downstream Implications}

Redox reactions (transfer of electrons between a donor and an acceptor) are very common in living organisms, which is responsible for the production of ROS [62]. In plant cells, redox homeostasis is developed in consequence of the equilibrium between the generation of ROS and the functioning of the antioxidant enzymes where efficient defense system in plants keeps the proper balance between ROS generation and elimination [63]. A basal level of ROS, which is maintained above cytostatic or below cytotoxic concentration is, therefore, indispensable for proper ROS or redox signaling in cells, and this level is maintained by the balance between ROS production and ROS scavenging $[4,11]$. Therefore, scientists used the term "redox biology" to refer to ROS as signaling molecules to control and uphold the usual physiological activities of plants $[11,64,65]$. Redox signaling has been discerned as the equilibrium between low levels of ROS functioning as signals to activate signaling cascades that adjust usual plant functions and high levels of ROS causing oxidative cellular damage [62]. Therefore, a steady balance between ROS generation and ROS scavenging systems is strongly synchronized over time and space, working together with the cellular redox-sensitive components to shape and finely adapt downstream signaling procedures in a cell-specific and context-specific approach [66,67]. However, any disturbance in the equilibrium of ROS generation and ROS scavenging by antioxidants leads to ROS overaccumulation resulting in oxidative stress under various abiotic stress conditions [9]. Oxidative stress causes lipid peroxidation, damages nucleic acids and proteins, and alters carbohydrate metabolism, resulting in cell dysfunction and death (Figure 4) $[4,68]$. 


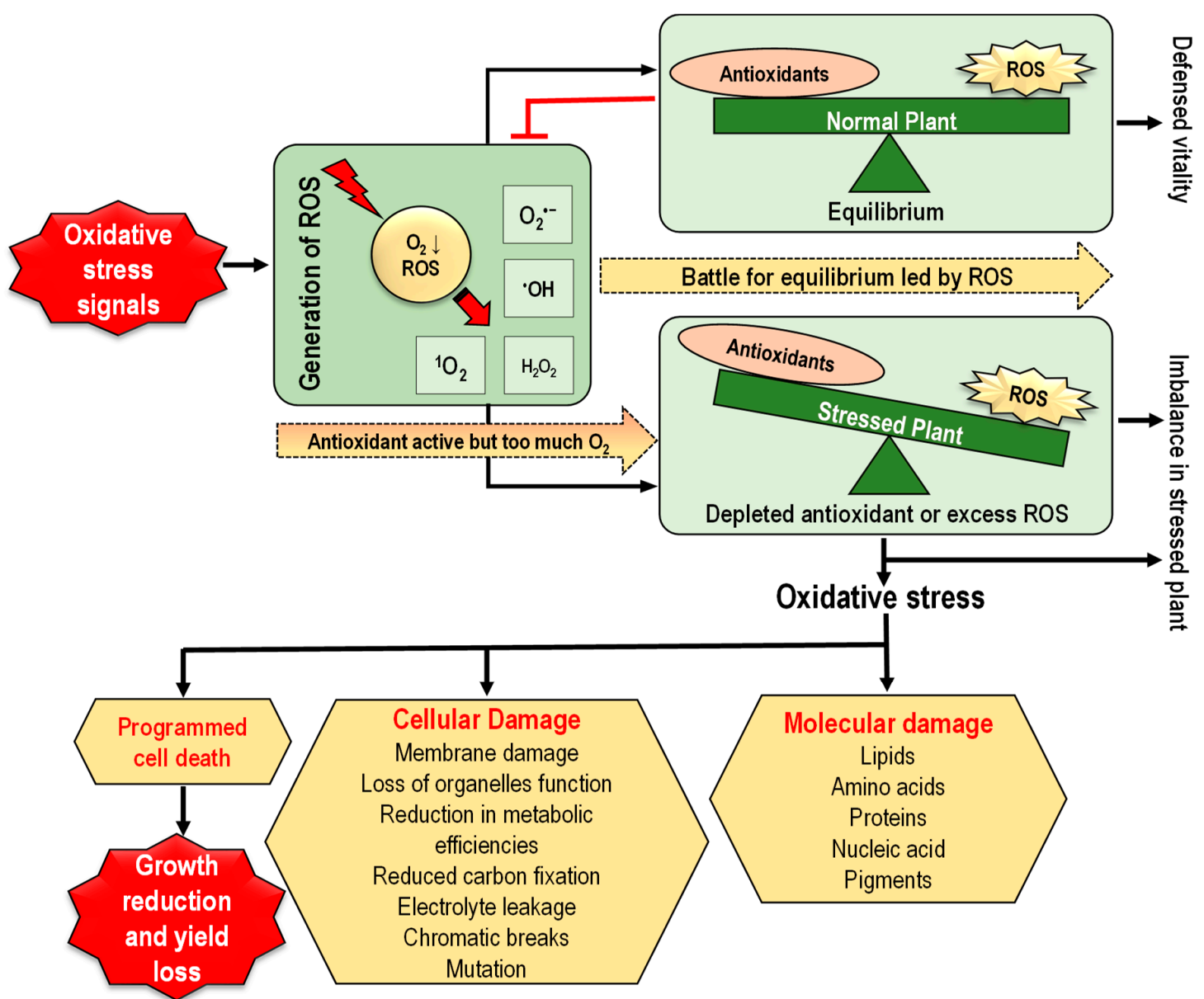

Figure 4. Oxidative stress in plants and its consequences (ROS, reactive oxygen species; ${ }^{1} \mathrm{O}_{2}$, singlet oxygen; $\mathrm{O}_{2}{ }^{\bullet-}$, superoxide anion; $\mathrm{H}_{2} \mathrm{O}_{2}$, hydrogen peroxide; ${ }^{\bullet} \mathrm{OH}$, hydroxyl radical).

\section{Oxidative Stress under Abiotic Stress}

Plants are sessile organisms that normally grow under field conditions. Therefore, in most regions of the world, they face excess light (sunny hours) during the hot season. Besides, different environmental/abiotic stresses generated due to anthropogenic activities and harsh climate changes are contributing in inducing oxidative stress through overgeneration of ROS. It is well established that chloroplasts, mitochondria, peroxisomes, apoplast, and plasma membranes are the primary sites of cellular ROS generation but chloroplasts are the leading sites for ROS production [6,40]. Most of the abiotic stresses reduce the availability of $\mathrm{CO}_{2}$ and hinder carbon fixation and contribute to successive reduction of molecular oxygen, which yields excess ROS and impairs the performance of chloroplasts, thus disturbing photosynthetic processes [8]. However, ROS generation greatly varies with plant species, genotypes, stress tolerance level, and duration of stress exposure (Table 1).

\subsection{Oxidative Stress under Salinity}

Salinity affects plants by imposing various complications such as ion toxicity, osmotic stress, nutritional deficiency, and genotoxicity, resulting in ROS overproduction and oxidative stress (Table 1) [69]. For instance, Rehman et al. [70] found a 2.5- and a 3-fold, increase in the production of $\mathrm{H}_{2} \mathrm{O}_{2}$ together with a 2- and a 3-fold increase in thiobarbituric acid reactive substances (TBARS) content under 100 and $200 \mathrm{mM}$ sodium chloride $(\mathrm{NaCl})$ stress, respectively, compared with control depicting salt-induced oxidative stress condition. It is also reported that the oxidative stress varies among the plant tissues under salt stress. For instance, it was reported that root tissues suffered most from 
salinity-induced oxidative stress, followed by mature and young leaves. Recently, Cheng et al. [71] reported that the total ROS content, lipid peroxidation, and electrolyte leakage (EL) in rice root tissues were two times higher under salt stress compared with the control. In another study, Ahanger et al. [72] reported an overaccumulation of $\mathrm{O}_{2}{ }^{--}$and $\mathrm{H}_{2} \mathrm{O}_{2}$ (by $157 \%$ and $176 \%$, respectively) together with increased malondialdehyde (MDA, by $94 \%$ ) content and EL (by 158\%) confirming salinity (100 mM $\mathrm{NaCl}$ )-induced oxidative stress in tomato. Similarly, both MDA and EL were increased by 2-fold due to salt stress (0.4\%) in sweet peppers [73], while a 2-fold increase in $\mathrm{H}_{2} \mathrm{O}_{2}, \mathrm{MDA}$, EL, and $\mathrm{O}_{2}{ }^{\bullet-}$ content was found to be caused in mung bean following $100 \mathrm{mM} \mathrm{NaCl}$ exposure [74]. Moreover, increased $\mathrm{H}_{2} \mathrm{O}_{2}$ (by $50 \%$ ) and MDA (by $25 \%$ ) content were noted in maize plants under salt stress $(120 \mathrm{mM} \mathrm{NaCl})$ compared with controls [75]. The extent of oxidative stress varied among genotypes within a species. Lalarukh and Shahbaz [76] exposed two sunflower genotypes (FH-572 and FH-621) to salt stress $(120 \mathrm{mM} \mathrm{NaCl})$ and observed that $\mathrm{H}_{2} \mathrm{O}_{2}$ content increased (by $78 \%$ ) in FH-572, while decreasing (by 20\%) in FH-621, indicating FH-621 as being more salt stress tolerant. In a similar study, Tariq and Shahbaz [77] evaluated two sesame genotypes (TS-5 and TH-6) against salt stress $(70 \mathrm{mM} \mathrm{NaCl})$ and concluded that TS- 5 showed comparatively better salt tolerance than TS-6. Similarly, Mhadhbi et al. [78] showed a genotype-dependent correlation between salinity tolerance and cellular damage indicators such as MDA and $\mathrm{H}_{2} \mathrm{O}_{2}$ content in Medicago truncatula genotypes under salt stress conditions. Interestingly, Ailanthus altissima plants growing under $150 \mathrm{mM} \mathrm{NaCl}$ had upregulated antioxidant enzymatic activities and no significant difference in $\mathrm{H}_{2} \mathrm{O}_{2}$ content compared with control plants, suggesting a link between the antioxidant defense apparatus and their increased invasiveness in adverse environments [79]. From these examples, it is evident that plants have differential responses towards salt-induced oxidative stress conditions.

\subsection{Oxidative Stress under Water Deficit and Simulated Drought}

Drought provokes stomatal closure, reduced $\mathrm{CO}_{2}$ entry, and impaired photosynthetic rate, as well as imbalance in the light harvest and utilization and altered photochemistry in chloroplasts, causing ROS overproduction $[4,80]$. Moreover, protein and membrane denaturation from photorespiration, inactivation of TCA cycle enzymes, and reduced carboxylation efficiency during drought are also linked with ROS overproduction [81]. Additionally, a lower $\mathrm{NADP}^{+}$regeneration causes greater reduction of ETC, higher EL under drought stress, ultimately resulting in excess ROS metabolism and oxidative stress $[82,83]$. Many studies have reported drought-induced ROS overproduction and oxidative stress in numerous plant species (Table 1). Abideen et al. [84] grew Phragmites karka under drought conditions by maintaining $40 \%$ water holding capacity for $35 \mathrm{~d}$ in a plastic tube and found $22 \%$ increase of MDA content. Under similar conditions, Campos et al. [85] recorded higher MDA content in Coffea arabica L. after $20 \mathrm{~d}$. Saha et al. [86] created drought conditions for rice plants by withdrawing irrigation for $8 \mathrm{~d}$ and found that in contrast to control, drought stress increased $\mathrm{O}_{2}{ }^{\bullet-}, \mathrm{H}_{2} \mathrm{O}_{2}$, and MDA content by 1.8-, 2.1-, and 1.66-fold, respectively. Severe drought stress (75\% water deficit condition) in finger millet plants considerably increased $\mathrm{EL}$ and $\mathrm{H}_{2} \mathrm{O}_{2}$ content [87]. In another study, Malhotra et al. [88] withheld irrigation in tomato plant for $6 \mathrm{~d}$, which resulted in an increase of MDA content as well as $39 \%$ augmentation of EL. Hasanuzzaman et al. [89] and [90] investigated the effect of hyperosmotic stress (10\% and $20 \%$ polyethylene glycol; PEG) on Brassica napus L. cv. Bina Sharisha-3 and found that both MDA and $\mathrm{H}_{2} \mathrm{O}_{2}$ increased under stress conditions. Similarly, hyperosmotic stress (5\% PEG, $48 \mathrm{~h}$ ) induced higher accumulation of $\mathrm{H}_{2} \mathrm{O}_{2}$ and $\mathrm{O}_{2}{ }^{\bullet-}$ with enhanced membrane peroxidation and LOX activity in Vigna radiata L. cv. BARI Mung-2 [91]. Abbas et al. [92] observed higher TBARS, EL, and $\mathrm{H}_{2} \mathrm{O}_{2}$ contents in wheat grown under water deficit condition ( $70 \%$ field capacity; FC). A similar increase in $\mathrm{O}_{2}{ }^{\bullet-}, \mathrm{H}_{2} \mathrm{O}_{2}$, and MDA content was observed in Oryza sativa L. var. japonica cv. Nipponbare grown under 20\% PEG-induced hyperosmotic stress [93]. Rezayian et al. [94] observed significantly increased MDA, $\mathrm{H}_{2} \mathrm{O}_{2}$ content, and LOX activity in 15\% PEG-stressed Glycine max plants compared with control samples. Rady et al. [95] exposed Solanum lycopersicum L. cv. Login 935 plants to drought stress $(60 \% \mathrm{FC}, 20 \mathrm{~d})$ and observed increased $\mathrm{O}_{2}{ }^{--}, \mathrm{H}_{2} \mathrm{O}_{2}$, and MDA contents by $75 \%, 37 \%$, and $83 \%$, 
respectively. In agreement with this, Filippou et al. [96] recorded significantly increased MDA and $\mathrm{H}_{2} \mathrm{O}_{2}$ content in $M$. truncatula plants under severe drought stress conditions, while parameters were reversed to prestress conditions following rewatering. The extent of drought severity also depends on the genotypic capability to cope with oxidative stress. Kusvuran and Dasgan [97] compared two Phaseolus vulgaris genotypes (Bn-150 (drought-tolerant) and Bn-16 (drought-sensitive)) under drought (50\% FC, 14 d), where Bn-16 exhibited 2-fold greater MDA content than Bn-150. Moreover, $\mathrm{O}_{2}{ }^{\bullet-}, \mathrm{H}_{2} \mathrm{O}_{2}$, and $\bullet \mathrm{OH}$ were also found to be higher in $\mathrm{Bn}-16$.

\subsection{Oxidative Stress under Metals/Metalloids Toxicity}

Metals/metalloids generate ROS in plant cells by disrupting the chloroplastic and mitochondrial electron transfer activities as well as peroxisomal oxidative metabolism. A number of studies demonstrated toxic metals-/metalloids-induced overproduction of ROS and subsequent oxidative damage in different plants (Table 1). A remarkable increase in lipid peroxidation along with the higher accumulation of $\mathrm{H}_{2} \mathrm{O}_{2}$ was observed in $O$. sativa seedlings grown under nickel ( $\mathrm{Ni} ; 0.25$ and $0.5 \mathrm{mM} \mathrm{NiSO}_{4}, 72 \mathrm{~h}$ ) toxicity [98]. El-Amier et al. [99] also reported similar results with lower levels of $\mathrm{Ni}\left(100 \mu \mathrm{M} \mathrm{Ni}\right.$ as $\left.\mathrm{NiCl}_{2}\right)$ in Pisum satioum. On the other hand, cadmium $(\mathrm{Cd})$ stress has been shown to increase $\mathrm{MDA}, \mathrm{H}_{2} \mathrm{O}_{2}$, and $\mathrm{O}_{2}{ }^{\bullet-}$ levels in different crops [100-102]. For example, Cd stress $\left(100 \mu \mathrm{M} \mathrm{CdCl}_{2}\right)$ resulted in increased MDA and $\mathrm{H}_{2} \mathrm{O}_{2}$ in Arabidopsis thaliana [103] and Cucumis sativus seedlings [104]. In a recent study, Ahanger et al. [105] reported that lipid peroxidation, $\mathrm{EL}_{2} \mathrm{H}_{2} \mathrm{O}_{2}$, and $\mathrm{O}_{2}{ }^{\bullet-}$ contents as well as LOX activity were markedly increased in $V$. angularis seedlings under $\mathrm{Cd}$ stress $\left(100 \mu \mathrm{M} \mathrm{CdCl}_{2}, 20 \mathrm{~d}\right)$, while a similar increase in EL, $\mathrm{H}_{2} \mathrm{O}_{2}$ and TBARS contents was recorded in Mentha arvensis under $\mathrm{Cd}$ stress $\left(50 \mu \mathrm{M} \mathrm{CdCl}_{2}, 100 \mathrm{~d}\right)$ [106]. Hasanuzzaman et al. [107] demonstrated higher $\mathrm{MDA}, \mathrm{H}_{2} \mathrm{O}_{2}$, and $\mathrm{O}_{2}{ }^{\bullet-}$ content in wheat plants subjected to lead $(\mathrm{Pb})$ stress $(0.5$ and $1.0 \mathrm{mM}$ $\left.\mathrm{Pb}\left(\mathrm{NO}_{3}\right)_{2}\right)$ compared with control. The nonredox metalloid arsenic (As) has also been reported to induce oxidative stress. Cajanus cajan seedlings exposed to $\mathrm{As}\left(10 \mu \mathrm{M}\right.$ As as $\left.\mathrm{Na}_{3} \mathrm{AsO}_{4}, 5 \mathrm{~d}\right) \mathrm{had}$ significantly higher $\mathrm{H}_{2} \mathrm{O}_{2}, \mathrm{O}_{2}{ }^{\bullet-}$, and MDA content, as well as 4-fold increased LOX activity compared with unstressed plants [108]. Such an increase in $\mathrm{H}_{2} \mathrm{O}_{2}$ and TBARS contents was also evident in two different cultivars of Chenopodium quinoa under higher levels of As (150 and $300 \mu \mathrm{M} \mathrm{Na}_{3} \mathrm{AsO}_{4}$, $35 \mathrm{~d})$ stress [109]. Interestingly, significant cellular damage in the form of increased $\mathrm{MDA}$ and $\mathrm{H}_{2} \mathrm{O}_{2}$ content was also observed in basil plants growing under copper $(\mathrm{Cu})$ stress (1000 ppm), although no significant increase in MDA content was observed in plants growing under milder $\mathrm{Cu}$ stress conditions (500 ppm) [110].

\subsection{Oxidative Stress under High Temperature}

High temperature (HT) leads to the overproduction of ROS, resulting in altered cellular metabolism, inactivated oxygen-evolving complex and increased lipid peroxidation, membrane damage, and nicking of DNA, and further, it drives to cell death (Table 1) [111]. High temperature $\left(35^{\circ} \mathrm{C} / 32{ }^{\circ} \mathrm{C}\right.$ day/night) blocked PSII reaction center and electron flow, reduced quantum efficiency (Fv/Fm), and downregulated PSII photochemistry in two rice cultivars (IR64 and Huanghuazhan) [112]. Ding et al. [113] reported a $79.9 \%$ increase in $\mathrm{O}_{2}{ }^{\bullet-}$ content cucumber (C. sativus L.) seedling due to HT stress $\left(35^{\circ} \mathrm{C}\right)$. In tobacco (Nicotiana tabacum cv. Bright-Yellow 2), HT $\left(50^{\circ} \mathrm{C}\right.$ ) increased $50 \%$ of $\mathrm{O}_{2}{ }^{\bullet-}$ content over a period of 5 min creating oxidative stress. Likewise, Djanaguiraman et al. [114] observed $\mathrm{O}_{2}^{\bullet-}$ content increased by 3.5-fold and 2.3-fold in pollen and pistils, respectively, in field-grown sorghum plants under HT stress, but Liu et al. [93] did not observe any significant change in $\mathrm{O}_{2}{ }^{\bullet-}$ and MDA content under HT stress $\left(38^{\circ} \mathrm{C}, 5 \mathrm{~d}\right)$, in spite of $\mathrm{H}_{2} \mathrm{O}_{2}$ increased by 1.27-fold in rice seeds compared with control samples.

\subsection{Oxidative Stress under Low Temperature}

Low temperature (LT) causes overproduction of ROS in plants through degradation of membrane fluidity, inhibiting photosynthetic apparatus activity, and imbalanced ROS detoxification, which lead to lipid peroxidation and EL (Table 1) [115]. Han et al. [116] showed increased MDA (by 180\%) and 
EL (by $49 \%$ ) contents in cold-stressed $\left(12{ }^{\circ} \mathrm{C}, 6 \mathrm{~d}\right)$ 14-d-old rice seedlings. Similarly, Liu et al. [117] treated a cold-sensitive S. lycopersicum (Jinpeng No. 1) genotype with LT stress $\left(15^{\circ} \mathrm{C} / 8^{\circ} \mathrm{C}\right.$ day/night; 24 and $48 \mathrm{~h}$ ), leading to significantly higher MDA and $\mathrm{H}_{2} \mathrm{O}_{2}$ content compared with controls. Similarly, Xue et al. [118] evaluated wild-type (WT) and transgenic (G-1 and G-2) Ammopiptanthus mongolicus for LT stress tolerance in a controlled system $\left(4{ }^{\circ} \mathrm{C}\right.$ for first $24 \mathrm{~h}, 0{ }^{\circ} \mathrm{C}$ for next $12 \mathrm{~h}$, and $-6{ }^{\circ} \mathrm{C}$ for last $12 \mathrm{~h}$ ) and found that WT plants accumulate higher levels of $\mathrm{H}_{2} \mathrm{O}_{2}$ compared with transgenic plants (detected through 3,3'-diaminobenzidine staining), indicating oxidative stress under LT stress.

\subsection{Oxidative Stress under Flooding}

Flooding or waterlogging (WL)-induced hypoxic or anoxic conditions generate toxic compounds that impair plant metabolism resulting in ROS overgeneration and oxidative damages (Table 1) [119]. Zhang et al. [120] also experimented with two Sorghum bicolor genotypes JN01 (WL-tolerant) and JN31 (WL-sensitive) and reported a remarkably higher accumulation of MDA in JN31 compared with JN01, at different duration $(6,9$, and $12 \mathrm{~d})$ of WL treatment. Anee et al. [121] studied the WL-sensitive Sesamum indicum L. cv. BARI Til-4 under different durations $(2,4,6$, and $8 \mathrm{~d})$ of WL stress and reported that MDA and $\mathrm{H}_{2} \mathrm{O}_{2}$ increased in a duration-dependent manner. Similar enhancement of these oxidative stress markers was also observed in S. lycopersicum [122]. However, an Antarctic plant, named Deschampsia antarctica, also produced higher MDA and $\mathrm{H}_{2} \mathrm{O}_{2}$ when exposed to WL condition for $7 \mathrm{~d}$ [123]. 
Table 1. Oxidative stress in plants under different abiotic stress factors.

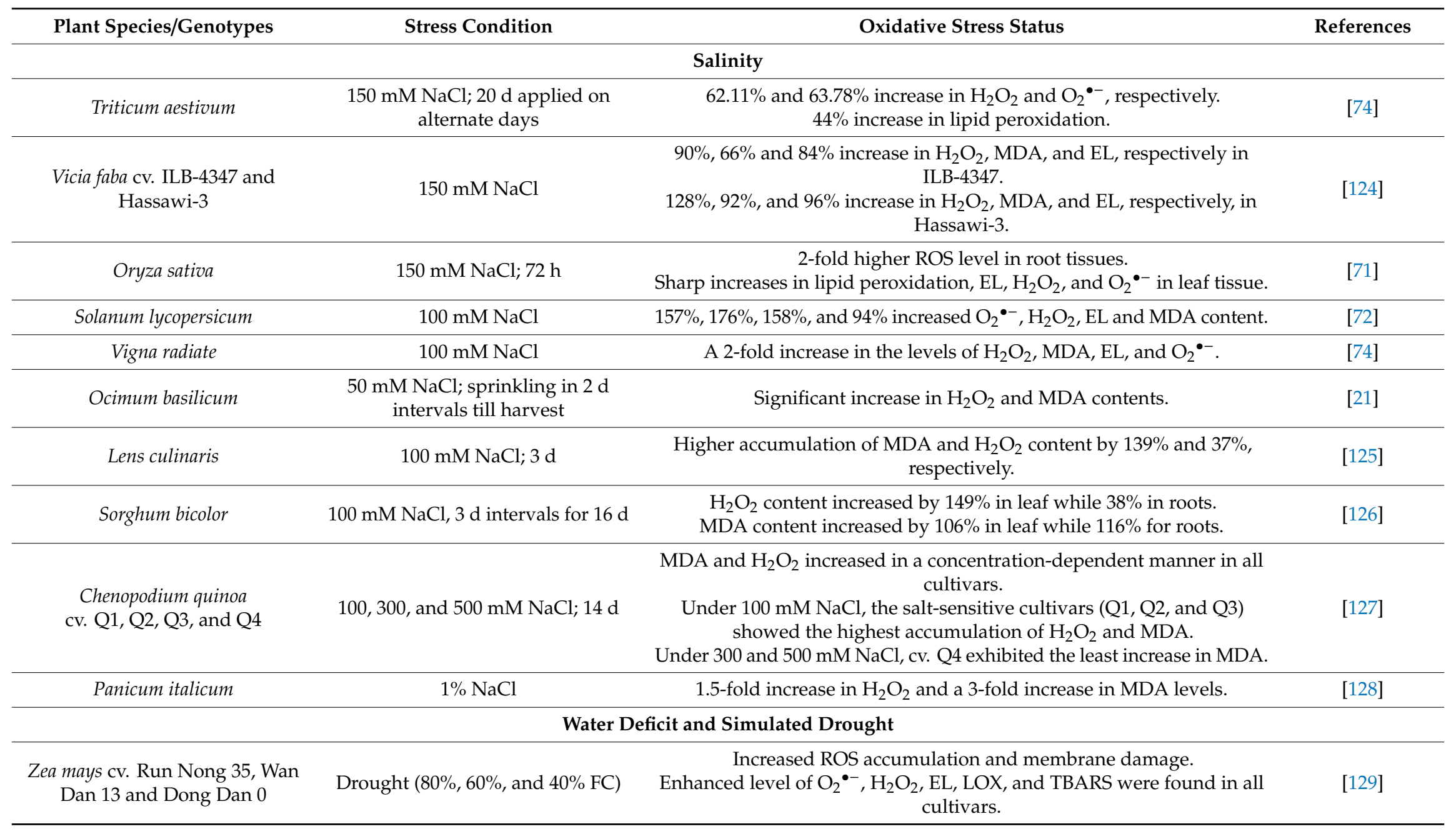


Table 1. Cont

\begin{tabular}{|c|c|c|c|}
\hline Plant Species/Genotypes & Stress Condition & Oxidative Stress Status & References \\
\hline Medicago sativa & Water deficit, $7 \mathrm{~d}$ & $\begin{array}{l}\text { Dramatically increased (by 5-fold) } \mathrm{H}_{2} \mathrm{O}_{2} \text { content. } \\
\text { Increased NO content (by } 15 \% \text { ) compared with control. }\end{array}$ & [130] \\
\hline Brassica napus Binasarisha-3 & $\begin{array}{l}\text { Osmotic stress ( } 10 \% \text { and } 20 \% \text { PEG) } \\
\qquad 48 \mathrm{~h}\end{array}$ & $\begin{array}{c}\text { Both levels of } \mathrm{H}_{2} \mathrm{O}_{2} \text { and MDA were upregulated significantly, with the } \\
\text { highest value in } 20 \% \text { PEG. }\end{array}$ & [89] \\
\hline $\begin{array}{l}\text { B. napus } \\
\text { cv. Bulbul-98 }\end{array}$ & Water deficit (30\% FC) & $\begin{array}{l}\text { Increased EL by 2-folds with membrane damage. } \\
\text { Significant increase in } \mathrm{H}_{2} \mathrm{O}_{2} \text { content. }\end{array}$ & [131] \\
\hline S. lycopersicum mill. cv. Pusa 120 & Drought (withheld irrigation), $6 \mathrm{~d}$ & Increased lipid peroxidation (MDA content) and EL (39\%). & [88] \\
\hline $\begin{array}{l}\text { V. radiata } \\
\text { cv. BARI Mung-2 }\end{array}$ & Osmotic stress (5\% PEG), $48 \mathrm{~h}$ & $\begin{array}{c}74 \% \text { and } 84 \% \text { increase in } \mathrm{H}_{2} \mathrm{O}_{2} \text { and } \mathrm{O}_{2}{ }^{\bullet-} \text { compared to control. } \\
62 \% \text { increase in LOX activity. }\end{array}$ & [91] \\
\hline S. bicolor cv. Sugargraze & Water deficit, $16 \mathrm{~d}$ & $\begin{array}{l}113 \% \text { increase in } \mathrm{H}_{2} \mathrm{O}_{2} \text { content. } \\
\text { Increased MDA content by } 94 \% \text { and } 98 \% \text { in leaf and root, respectively. } \\
\text { A drastic loss in cell viability. }\end{array}$ & [126] \\
\hline T. aestivum & Drought $(35 \%$ FC) & $\begin{array}{c}31 \%, 25 \% \text {, and } 38 \% \text { increase in TBARS, EL, and } \mathrm{H}_{2} \mathrm{O}_{2} \text { contents, } \\
\text { respectively, compared to control. }\end{array}$ & [92] \\
\hline B. napus cv. BINA Sharisha-3 & $\begin{array}{l}\text { Osmotic stress (10\% and } 20 \% \text { PEG) } \\
\qquad 48 \mathrm{~h}\end{array}$ & $123 \%$ and $93 \%$ increased MDA and $\mathrm{H}_{2} \mathrm{O}_{2}$ content over control. & {$[90]$} \\
\hline $\begin{array}{l}\text { O. sativa, sub1A quantitative } \\
\text { trait loci (sub1A QTL) }\end{array}$ & $\begin{array}{l}\text { Drought (withdrawing irrigation), } \\
8 \mathrm{~d}\end{array}$ & $\begin{array}{l}\text { Increased } \mathrm{O}_{2}{ }^{\bullet-}, \mathrm{H}_{2} \mathrm{O}_{2} \text { and } \mathrm{MDA} \text { content by } 1.8-, 2.1-\text {, and 1.66-folds, } \\
\text { respectively. }\end{array}$ & [86] \\
\hline Eleusine coracana L. Gaertn. & $\begin{array}{l}\text { Drought ( } 75 \% \text { water deficit } \\
\text { condition), } 3 \mathrm{w}\end{array}$ & Increased EL and $\mathrm{H}_{2} \mathrm{O}_{2}$ content. & [87] \\
\hline B. rapa cv. BARI Sharisha-15 & Osmotic stress (20\% PEG), $2 \mathrm{~d}$ & $\begin{array}{l}82 \% \text { and } 131 \% \text { increased MDA and } \mathrm{H}_{2} \mathrm{O}_{2} \text { content over control. } \\
\text { Overproduction of toxic } \mathrm{O}_{2}{ }^{\circ-} \text {. }\end{array}$ & [132] \\
\hline Coffea arabica L. & $\begin{array}{l}\text { Drought ( } 40 \% \text { water holding } \\
\text { capacity), } 20 \mathrm{~d}\end{array}$ & Increased MDA content. & [85] \\
\hline $\begin{array}{l}\text { O. sativa var. japonica. } \mathrm{cv} \text {. } \\
\text { Nipponbare }\end{array}$ & Osmotic stress (20\% PEG-6000), $5 \mathrm{~d}$ & $\begin{array}{c}16 \% \text { and } 23 \% \text { increased MDA and } \mathrm{O}_{2}^{\bullet-} \text { accumulation comparing control. } \\
\text { 1-fold enhanced } \mathrm{H}_{2} \mathrm{O}_{2} \text { generation over control. }\end{array}$ & [93] \\
\hline
\end{tabular}


Table 1. Cont

\begin{tabular}{|c|c|c|c|}
\hline Plant Species/Genotypes & Stress Condition & Oxidative Stress Status & References \\
\hline Phragmites karka & $\begin{array}{l}\text { Drought ( } 40 \% \text { water holding } \\
\text { capacity), } 35 \mathrm{~d}\end{array}$ & Increased MDA content by $22 \%$. & [84] \\
\hline S. lycopersicum cv. Login 935 & Water deficit (60\% FC), $20 \mathrm{~d}$ & $\begin{array}{l}83 \%, 37 \% \text {, and } 75 \% \text { increased } \mathrm{MDA}, \mathrm{H}_{2} \mathrm{O}_{2} \text {, and } \mathrm{O}_{2}{ }^{\bullet-} \text { content compared } \\
\text { to control. }\end{array}$ & [95] \\
\hline Glycine max & Osmotic stress (15\% PEG), $3 \mathrm{w}$ & $47 \%$ declined EL, while LOX activity enhanced by $38 \%$. & [94] \\
\hline \multicolumn{4}{|c|}{ Toxic Metals/Metalloids } \\
\hline O. sativa cv. BRRI dhan 54 & 0.25 and $0.5 \mathrm{mM} \mathrm{NiSO}_{4} .7 \mathrm{H}_{2} \mathrm{O}, 3 \mathrm{~d}$ & 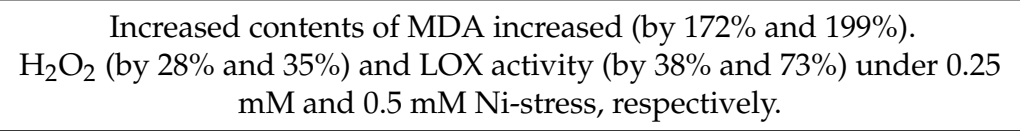 & [98] \\
\hline B. juncea cv. BARI Sharisha-11 & 0.5 and $1.0 \mathrm{mM} \mathrm{CdCl}_{2}, 3 \mathrm{~d}$ & $\begin{array}{c}\text { Enhanced MDA content by } 35 \% \text { and } 66 \%, \mathrm{H}_{2} \mathrm{O}_{2} \text { content by } 43 \% \text { and } \\
54 \% \text {, and LOX activity by } 69 \% \text { and } 108 \% \text { under } 0.5 \text { and } 1.0 \mathrm{mM} \mathrm{Cd} \text { stress, } \\
\text { respectively. }\end{array}$ & [102] \\
\hline B. napus BINA Sharisha-3 & 0.5 and $1.0 \mathrm{mM} \mathrm{CdCl}_{2}, 2 \mathrm{~d}$ & $\begin{array}{l}\text { Increased MDA contents by } 56 \% \text { and } 133 \% \text {, and } \mathrm{H}_{2} \mathrm{O}_{2} \text { contents by } 38 \% \\
\text { and } 70 \% \text { in } 0.5 \text { and } 1.0 \mathrm{mM} \mathrm{Cd} \text { stress, respectively. }\end{array}$ & [101] \\
\hline V. radiata $\mathrm{cv}$. BARI Mung-2 & 1.0 and $1.5 \mathrm{mM} \mathrm{CdCl}_{2}, 2 \mathrm{~d}$ & $\begin{array}{c}\text { Increased MDA level by } 85 \% \text { and } 177 \%, \mathrm{H}_{2} \mathrm{O}_{2} \text { content by } 73 \% \text { and } 127 \% \\
\text { and } \mathrm{O}_{2}{ }^{\bullet-} \text { generation rate by } 69 \% \text { and } 120 \% \text { under } 1.0 \text { and } 1.5 \mathrm{mM} \mathrm{Cd} \\
\text { stresses, respectively. }\end{array}$ & [100] \\
\hline T. aestivum cv. Pradip & 0.5 and $1.0 \mathrm{mM} \mathrm{Pb}\left(\mathrm{NO}_{3}\right)_{2}, 2 \mathrm{~d}$ & $\begin{array}{c}\text { MDA content increased by } 58 \% \text { and } 179 \% \text { and } \mathrm{H}_{2} \mathrm{O}_{2} \text { levels by } 41 \% \text { and } \\
95 \% \text { under both levels of } \mathrm{Pb} \text { stress. }\end{array}$ & [107] \\
\hline V. radiata cv. BARI mung-2 & $0.5 \mathrm{mM} \mathrm{AlCl}, 2$ and $3 \mathrm{~d}$ & $\begin{array}{l}\mathrm{H}_{2} \mathrm{O}_{2}, \mathrm{O}_{2}^{\bullet-} \text { generation rate, and LOX activity increased by } 83 \%, 110 \% \text {, } \\
\text { and } 72 \% \text {, which increased the lipid peroxidation by } 97 \% \text {. }\end{array}$ & [133] \\
\hline B. juncea cv. BARI Sharisha-11 & 0.15 and $0.3 \mathrm{mM} \mathrm{K}_{2} \mathrm{CrO}_{4}, 5 \mathrm{~d}$ & $\begin{array}{c}\text { Increased TBARS content (by } 30 \% \text { and } 65 \% \text { ), } \mathrm{H}_{2} \mathrm{O}_{2} \text { (by } 24 \% \text { and } 46 \% \text { ), } \\
\text { and LOX activity (by } 68 \% \text { and } 101 \% \text { ) under both levels of Cr stress, } \\
\text { respectively. }\end{array}$ & [104] \\
\hline \multicolumn{4}{|c|}{ Extreme Temperature } \\
\hline Cucumis sativus & $35 \pm 1{ }^{\circ} \mathrm{C}, 7$ days & Increased MDA content (by 60.6\%) and $\mathrm{O}_{2}^{-}$(by 79.9\%). & [113] \\
\hline S. bicolor & $\begin{array}{l}36 / 26^{\circ} \mathrm{C} \text { and } 39 / 29^{\circ} \mathrm{C} \text {, until } 7 \mathrm{~d} \\
\text { after full anthesis }\end{array}$ & $\mathrm{O}_{2}^{\bullet-}$ content increased 2 to 4 -fold in pollen and 1 to 2.3 -folds in the pistil. & [114] \\
\hline Gossypium hirsutum & $45 / 30 \pm 2{ }^{\circ} \mathrm{C}, 120 \mathrm{~d}$ & Enhanced MDA content by $0.78 \%$, affecting fiber quality and boll weight. & [134] \\
\hline
\end{tabular}


Table 1. Cont

\begin{tabular}{|c|c|c|c|}
\hline Plant Species/Genotypes & Stress Condition & Oxidative Stress Status & References \\
\hline O. sativa & $38^{\circ} \mathrm{C}, 5 \mathrm{~d}$ & $\mathrm{H}_{2} \mathrm{O}_{2}$ accumulation increased 1-fold. & [93] \\
\hline O. sativa cv. DM You 6188) & $12{ }^{\circ} \mathrm{C}$, for $6 \mathrm{~d}$ & Enhanced MDA content and EL by $180 \%$ and $49 \%$, respectively. & [116] \\
\hline L. esculentum. cv. C.H Falat & $3{ }^{\circ} \mathrm{C}, 6 \mathrm{~h}, 6 \mathrm{~d}$ & Enhanced $\mathrm{H}_{2} \mathrm{O}_{2}$ content (by 2-fold) and EL (by 20\%). & [136] \\
\hline Solanum lycopersicum L. & $15 / 8^{\circ} \mathrm{C}$ day/night, 24 and $48 \mathrm{~h}$ & Increased MDA and $\mathrm{H}_{2} \mathrm{O}_{2}$ by $62 \%$ and $34 \%$, respectively. & [117] \\
\hline \multicolumn{4}{|c|}{ Waterlogging } \\
\hline S. bicolor cvs. JN01 and JZ31 & Waterlogged soil, $12 \mathrm{~d}$ & $\begin{array}{l}\text { 2.45-fold higher MDA content in WL-sensitive JZ31, but 1.8-fold higher } \\
\text { in WL-tolerant JN01. }\end{array}$ & [120] \\
\hline $\begin{array}{l}\text { Hordeum vulgare cvs. TF57 and } \\
\text { TF58 }\end{array}$ & Waterlogged soil, $21 \mathrm{~d}$ & $\begin{array}{l}\text { MDA content and } \mathrm{O}_{2}^{\bullet-} \text { generation rate } \sigma \text { were markedly increased in } \\
\text { WL-sensitive TF57, but slightly increased in WL-tolerant TF58 genotype. }\end{array}$ & [137] \\
\hline S. lycopersicum cv. Roma & Waterlogged soil, $15 \mathrm{~d}$ & $54 \%$ and $208 \%$ higher MDA and $\mathrm{H}_{2} \mathrm{O}_{2}$ contents, respectively. & [122] \\
\hline Deschampsia Antarctica & Waterlogged soil, $7 \mathrm{~d}$ & $84 \%$ and $52 \%$ higher MDA and $\mathrm{H}_{2} \mathrm{O}_{2}$ contents. & [123] \\
\hline Sesamum indicum cv. BARI Til-4 & Waterlogged soil, 2, 4, 6, and $8 \mathrm{~d}$ & $\begin{array}{l}\text { Both MDA and } \mathrm{H}_{2} \mathrm{O}_{2} \text { increased in a duration-dependent manner } \\
39 \% \text { and } 62 \% \text { higher MDA and } \mathrm{H}_{2} \mathrm{O}_{2} \text { content after } 8 \text { days of WL. }\end{array}$ & [121] \\
\hline
\end{tabular}




\section{Overview of Plant Antioxidant Defense System}

Antioxidants directly or indirectly scavenge ROS and/or control ROS production [138]. The antioxidant defense system consists of low-molecular-weight nonenzymatic antioxidants and some antioxidant enzymes [4]. The nonenzymatic antioxidants such as AsA, GSH, $\alpha$-tocopherol, phenolic compounds ( $\mathrm{PhOH}$ ), flavonoids, alkaloids, and nonprotein amino acids work in a coordinated fashion with antioxidant enzymes such as SOD, CAT, POX, polyphenol oxidase (PPO), APX, MDHAR, DHAR, GR, GPX, GST, TRX, and PRX in order to inhibit overproduction of ROS (Figure 5) [139,140]. The catalytic reaction of enzymatic and nonenzymatic antioxidants and the reaction sites in cellular organ is represented in Table 2. In plants, the enzyme SOD is directly related to stress, which initiates the first line of defense, converting $\mathrm{O}_{2}{ }^{\bullet-}$ into $\mathrm{H}_{2} \mathrm{O}_{2}$ (Table 2) [141,142]. This generated $\mathrm{H}_{2} \mathrm{O}_{2}$ can be further converted into $\mathrm{H}_{2} \mathrm{O}$ by the enzymes CAT, APX, GPX, or catalyzed in the AsA-GSH cycle. In plant cell, the AsA-GSH cycle or Asada-Halliwell cycle is the major antioxidant defense pathway to detoxify $\mathrm{H}_{2} \mathrm{O}_{2}$, which consist nonenzymatic antioxidants AsA and GSH as well as four important enzymes APX, MDHAR, DHAR, and GR. In the antioxidant defense system, a key role is performed by the AsA-GSH cycle to minimize $\mathrm{H}_{2} \mathrm{O}_{2}$ and redox homeostasis [4,143]. In addition, GPX and GST are also vital enzymes for the detoxification of $\mathrm{H}_{2} \mathrm{O}_{2}$ and xenobiotics (Figure 5) [144]. Among nonenzymatic antioxidants, AsA and GSH are the most abundant soluble antioxidants in higher plants [145], those play a vital role as electron donors and scavenge ROS directly through AsA-GSH cycle [4]. Moreover, beta-carotene reacts with ${ }^{\bullet} \mathrm{OH}, \mathrm{O}_{2}{ }^{\bullet-}$, and $\mathrm{ROO}^{\bullet}$ radicals resulting in reduced cellular ROS concentrations [146].

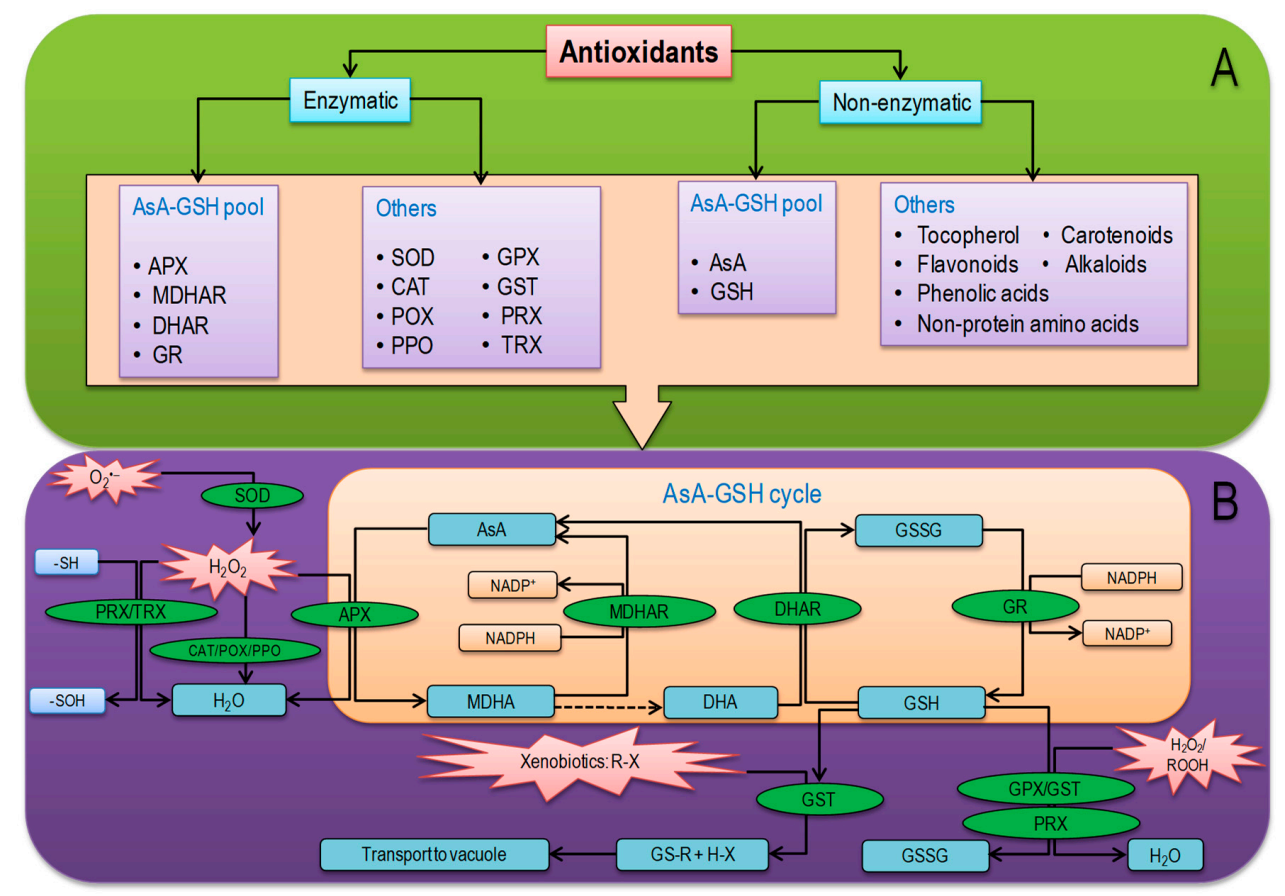

Figure 5. Overview of plant antioxidant defense system: (A) types of antioxidants and (B) combined mechanisms of enzymatic and nonenzymatic antioxidants. See the text for a more detailed description. APX, ascorbate peroxidase; AsA, ascorbate; CAT, catalase; DHA, dehydroascorbate; DHAR, dehydroascorbate reductase; GPX, glutathione peroxidase; GR, glutathione reductase; GSH, reduced glutathione; GSSG, oxidized glutathione; GST, glutathione $S$-transferase; $\mathrm{H}_{2} \mathrm{O}_{2}$, hydrogen peroxide; MDHA, monodehydroascorbate; MDHAR, monodehydroascorbate reductase; NADPH, nicotinamide adenine dinucleotide phosphate; $\mathrm{O}_{2}{ }^{\bullet-}$, superoxide anion; POX, peroxidases; PRX, peroxiredoxins; $\mathrm{R}$, aliphatic, aromatic, or heterocyclic group; $\mathrm{ROOH}$, hydroperoxides; $-\mathrm{SH}$, thiolate; $\mathrm{SOD}$, superoxide dismutase; $-\mathrm{SOH}$, sulfenic acid; TRX, thioredoxin; $\mathrm{X}$, sulfate, nitrite, or halide group. 


\subsection{Nonenzymatic Antioxidants}

Ascorbate plays a significant role in AsA-GSH cycle to scavenge ROS through its capacity to donate electrons and remain stable due to electron delocalization that results from the resonance between two forms [4]. Many phytohormone biosynthesis pathways are regulated by AsA. Moreover, AsA regenerates $\alpha$-tocopherol (vitamin E) from tocopheroxyl radical or by scavenging of ${ }^{\bullet} \mathrm{OH}$ and $\mathrm{O}_{2}{ }^{\bullet-}[147,148]$. Contrarily, another vital component of the antioxidant defense system, GSH, plays a significant role in the regulation of AsA-GSH cycle for scavenging cellular ROS and redox homeostasis [4]. Tocopherol protects the chloroplast and maintains photosynthesis by scavenging ROS, mainly ${ }^{1} \mathrm{O}_{2}$ and ${ }^{\bullet} \mathrm{OH}$ [149]. Carotenoids constitute another important class of antioxidant molecules, which are known to scavenge harmful free radicals, as well as to protect light-harvesting complex proteins and thylakoid membrane stability $[3,150]$. Low-molecular-weight compound flavonoids and, especially, dihydroxy B-ring-substituted flavones and flavonols have great potential to scavenge free radicals and reduce cell damage from lipid peroxidation [151-153]. Moreover, abiotic stresses upregulated the expression of genes related to flavonoids biosynthesis and activate antioxidant defense mechanisms [3]. The antioxidant phenolic acids are mainly composed of hydroxybenzoic and hydroxycinnamic acids, those show antioxidant activity as chelators and scavengers of free radicals, especially $\mathrm{O}_{2}^{\bullet-},{ }^{\bullet} \mathrm{OH}, \mathrm{ROO}^{\bullet}$, and $\mathrm{ONOO}^{-}$[138]. Alkaloids also have antioxidant ability as free radical scavengers and inhibit $\mathrm{H}_{2} \mathrm{O}_{2}$-induced oxidation [154]. Furthermore, nonprotein amino acids (gamma-aminobutyric acid, ornithine, and citrulline) are also considered as effective nonenzymatic antioxidant [155].

\subsection{Antioxidant Enzymes}

Superoxide dismutase (SOD; EC 1.15.1.1), categorized into three main types-Cu/Zn-SOD, Fe-SOD, and $\mathrm{Mn}-\mathrm{SOD}$, leads the frontline defense in the antioxidant defense system by dismutating $\mathrm{O}_{2}{ }^{\bullet-}$ into $\mathrm{H}_{2} \mathrm{O}_{2}$ and reducing the possibility of ${ }^{\bullet} \mathrm{OH}$ formation [156]. In the antioxidant defense system, catalase (CAT; EC 1.11.1.6) is a tetrameric heme-containing enzyme for ROS detoxification, which converts 26 million $\mathrm{H}_{2} \mathrm{O}_{2}$ molecules into $\mathrm{H}_{2} \mathrm{O}$ in 1 minute [3]. Peroxidase (EC. 1.11.1.7) mainly oxidizes $\mathrm{PhOH}$ for producing phenoxyl radical $\left(\mathrm{PhO}^{\bullet}\right.$ ) more commonly referred to $\mathrm{Q}_{\mathrm{A}}$, where $\mathrm{H}_{2} \mathrm{O}_{2}$ accepts electron and is converted to $\mathrm{H}_{2} \mathrm{O}$. In the absence of AsA, $\mathrm{PhO}^{\bullet}$ cross-reacts producing suberin, lignin, and quinines, but in the presence of $\mathrm{AsA}, \mathrm{PhO}^{\bullet}$ reacts with AsA generating monodehydroascorbate (MDHA) and, subsequently, DHA (Figure 5 and Table 2) [157].

Table 2. Reaction mechanisms of major reactive oxygen species (ROS) scavenging enzymatic antioxidants.

\begin{tabular}{|c|c|c|}
\hline Antioxidants & Reactions Catalyzed & Catalytic Reaction Sites \\
\hline \multicolumn{3}{|c|}{ Nonenzymatic } \\
\hline Ascorbic acid & $\begin{array}{c}\text { Scavenges } \mathrm{O}_{2}{ }^{\bullet-}, \mathrm{H}_{2} \mathrm{O}_{2},{ }^{\bullet} \mathrm{OH}, \\
\text { and }{ }^{1} \mathrm{O}_{2}\end{array}$ & $\begin{array}{c}\text { Chloroplast, peroxisomes, cytosol, } \\
\text { mitochondria, apoplast }\end{array}$ \\
\hline Glutathione & Scavenges $\mathrm{H}_{2} \mathrm{O}_{2}, \cdot \mathrm{OH}$, and ${ }^{1} \mathrm{O}_{2}$ & $\begin{array}{c}\text { Chloroplast, peroxisomes, cytosol, } \\
\text { mitochondria, apoplast }\end{array}$ \\
\hline Tocopherol & $\begin{array}{c}\text { Scavenges }{ }^{\bullet} \mathrm{OH},{ }^{1} \mathrm{O}_{2}, \mathrm{ROO}^{\bullet} \text { and } \\
\mathrm{ROOH}\end{array}$ & $\begin{array}{c}\text { Thylakoid membrane of } \\
\text { chloroplast }\end{array}$ \\
\hline Carotenoids & Scavenges mainly ${ }^{1} \mathrm{O}_{2}$ & Chloroplast \\
\hline Flavonoids & Scavenges $\mathrm{O}_{2}{ }^{\bullet-}, \mathrm{H}_{2} \mathrm{O}_{2}$, and ${ }^{1} \mathrm{O}_{2}$ & Chloroplast, vacuole \\
\hline Phenolic acids & $\begin{array}{c}\text { Scavenges } \mathrm{O}_{2}^{\bullet-}, \cdot \mathrm{OH}^{-} \mathrm{ROO}^{\bullet}, \\
\text { and } \mathrm{ONOO}^{-}\end{array}$ & Cell wall \\
\hline Alkaloids & $\begin{array}{c}\text { Scavenges } \mathrm{O}_{2}{ }^{\bullet-}, \bullet \mathrm{OH}, \mathrm{H}_{2} \mathrm{O}_{2}, \\
\text { and }{ }^{1} \mathrm{O}_{2}\end{array}$ & Vacuole \\
\hline Nonprotein amino acids & Scavenges $\mathrm{O}_{2}{ }^{\bullet-}, \mathrm{H}_{2} \mathrm{O}_{2}$, and ${ }^{1} \mathrm{O}_{2}$ & Cytosol, mitochondria, cell wall \\
\hline
\end{tabular}


Table 2. Cont.

\begin{tabular}{|c|c|c|}
\hline Antioxidants & Reactions Catalyzed & Catalytic Reaction Sites \\
\hline \multicolumn{3}{|c|}{ Enzymatic } \\
\hline $\begin{array}{l}\text { Superoxide dismutase } \\
\text { (SOD; EC 1.15.1.1) }\end{array}$ & $2 \mathrm{O}_{2}^{\bullet-}+2 \mathrm{H}^{+} \rightarrow \mathrm{O}_{2}+\mathrm{H}_{2} \mathrm{O}_{2}$ & $\begin{array}{l}\text { Chloroplast, peroxisomes, cytosol, } \\
\text { mitochondria, apoplast }\end{array}$ \\
\hline $\begin{array}{c}\text { Catalase } \\
\text { (CAT; EC 1.11.1.6) }\end{array}$ & $2 \mathrm{H}_{2} \mathrm{O}_{2} \rightarrow 2 \mathrm{H}_{2} \mathrm{O}+\mathrm{O}_{2}$ & Peroxisomes \\
\hline $\begin{array}{c}\text { Peroxidases } \\
\text { (POX; EC 1.11.1.7) }\end{array}$ & $\begin{array}{c}2 \mathrm{PhOH}+\mathrm{H}_{2} \mathrm{O}_{2} \rightarrow 2 \mathrm{PhO}^{\bullet}+2 \mathrm{H}_{2} \mathrm{O} \\
2 \mathrm{PhO}^{\bullet} \rightarrow \text { cross-linked substances } \\
\mathrm{PhO}^{\bullet}+\text { Asc } \rightarrow \text { PhOH }+ \text { MDHA } \\
\mathrm{PhO}^{\bullet}+\mathrm{MDHA} \rightarrow \mathrm{PhOH}+\mathrm{DHA}\end{array}$ & Cell wall, apoplast, vacuole \\
\hline $\begin{array}{l}\text { Polyphenol oxidase } \\
\text { (PPO; EC 1.14.18.1) }\end{array}$ & $\begin{array}{c}\mathrm{PhOH}+\mathrm{O}_{2} \rightarrow \text { Catechols } \\
\text { Catechols }+\mathrm{O}_{2} \rightarrow \mathrm{Q}+\mathrm{H}_{2} \mathrm{O}\end{array}$ & $\begin{array}{l}\text { Thylakoid membrane of } \\
\text { chloroplast, cytosol, vacuole }\end{array}$ \\
\hline $\begin{array}{l}\text { Ascorbate peroxidase } \\
\text { (APX; EC 1.11.1.11) }\end{array}$ & $\mathrm{H}_{2} \mathrm{O}_{2}+\mathrm{AsA} \rightarrow 2 \mathrm{H}_{2} \mathrm{O}+\mathrm{MDHA}$ & $\begin{array}{l}\text { Chloroplast, peroxisomes, cytosol, } \\
\text { mitochondria, apoplast }\end{array}$ \\
\hline $\begin{array}{c}\text { Monodehydroascorbate reductase } \\
\text { (MDHAR; EC 1.6.5.4) }\end{array}$ & $\begin{array}{c}\mathrm{MDHA}+\mathrm{NAD}(\mathrm{P}) \mathrm{H} \rightarrow \mathrm{AsA}+ \\
\mathrm{NAD}(\mathrm{P})^{+}\end{array}$ & Chloroplast, cytosol, mitochondria \\
\hline $\begin{array}{l}\text { Dehydroascorbate reductase } \\
\text { (DHAR; EC 1.8.5.1) }\end{array}$ & $2 \mathrm{GSH}+\mathrm{DHA} \rightarrow \mathrm{GSSG}+\mathrm{AsA}$ & Chloroplast, cytosol, mitochondria \\
\hline $\begin{array}{l}\text { Glutathione reductase } \\
\text { (GR; EC 1.6.4.2) }\end{array}$ & $\begin{array}{c}\mathrm{GSSG}+\mathrm{NADPH}+\mathrm{H}^{+} \rightarrow \mathrm{GSH}+ \\
\mathrm{NADP}^{+}\end{array}$ & Chloroplast, cytosol, mitochondria \\
\hline $\begin{array}{l}\text { Glutathione peroxidase } \\
\text { (GPX; EC 1.11.1.9) }\end{array}$ & $\mathrm{H}_{2} \mathrm{O}_{2}+\mathrm{GSH} \rightarrow \mathrm{H}_{2} \mathrm{O}+\mathrm{GSSG}$ & Cytosol, mitochondria \\
\hline $\begin{array}{c}\text { Glutathione S-transferase } \\
\text { (GST; EC 2.5.1.18) }\end{array}$ & $\mathrm{R}-\mathrm{X}+\mathrm{GSH} \rightarrow \mathrm{GS}-\mathrm{R}+\mathrm{H}-\mathrm{X}$ & Chloroplast, cytosol, mitochondria \\
\hline $\begin{array}{l}\text { Peroxiredoxins } \\
\text { (PRX; EC 1.11.1.15) }\end{array}$ & $\begin{array}{c}\mathrm{H}_{2} \mathrm{O}_{2}+\mathrm{PRX}^{-} \mathrm{S}^{-} \rightarrow \mathrm{OH}^{-}+ \\
\text {PRX-SOH } \\
\mathrm{PRX}-\mathrm{SOH}+\mathrm{GSH} \rightarrow \mathrm{PRX}-S S G^{\mathrm{G} H} \\
\mathrm{H}_{2} \mathrm{O} \\
\text { PRX-SSG }+\underset{\mathrm{GSH} \rightarrow \mathrm{PRX}^{-} \mathrm{S}^{-}+}{\mathrm{GSSG}}\end{array}$ & $\begin{array}{l}\text { Cytosol, chloroplasts, } \\
\text { mitochondria, nucleus, } \\
\text { extracellular spaces }\end{array}$ \\
\hline $\begin{array}{l}\text { Thioredoxin } \\
\text { (TRX; EC 1.8. 1.9) }\end{array}$ & $\begin{array}{l}\mathrm{TRX}_{-\mathrm{RS}_{2}}+\mathrm{NADPH}+\mathrm{H}^{+} \rightarrow \\
\text { TRX-R(SH) })_{2}+\mathrm{NADP}^{+}\end{array}$ & Chloroplast, cytosol, mitochondria \\
\hline
\end{tabular}

Polyphenol oxidase (EC 1.14.18.1) mostly found in thylakoid membrane of chloroplast can influence photosynthesis directly. The enzyme polyphenol oxidase could also interact with peroxidase, or water-water cycle to facilitate ROS scavenging. PPO oxidizes $\mathrm{PhOH}$ to $\mathrm{Q}_{\mathrm{A}}$ and $\mathrm{H}_{2} \mathrm{O}$ by using available $\mathrm{O}_{2}$ [158]. In plant cells, AsA-dependent APX (EC 1.11.1.1) occurs in different isoforms (cytosolic APX (cAPX), mitochondrial APX (mtAPX), chloroplastic APX (chlAPX; APX is the only enzyme capable of scavenging $\mathrm{H}_{2} \mathrm{O}_{2}$ in chloroplast since CAT is not present), and peroxisomal/glyoxysomal APX (mAPX; including)) and are $\mathrm{H}_{2} \mathrm{O}_{2}$ scavengers, which participates in AsA-GSH cycle producing monodehydroascorbate (MDHA) [159]. The produced MDHA is converted to AsA by a NADPH-dependent flavin adenine dinucleotide enzyme-MDHAR (EC 1.6.5.4)—found as two isoforms in various cellular locations [4]. Monodehydroascorbate reductase containing a thiol group regenerates AsA by phenoxyl radical reduction [160]. Monodehydroascorbate is further reduced into DHA nonenzymatically, which is then recycled to AsA by the activity of GSH-dependent DHAR (EC1.8.5.1) activity [160]. In this reaction, GSH is oxidized to GSSG that is further reduced to GSH by NADPH-dependent GR (EC 1.6.4.2) enzyme, which is also vital for the regulation of redox homeostasis [161]. Beyond, GPX (EC 1.11.1.9) is a member of nonheme containing POX family antioxidant enzyme having a highly reactive thiol group, which utilizes GSH and TRXs to scavenge $\mathrm{H}_{2} \mathrm{O}_{2}$, reducing lipids, and organic hydroperoxides [162]. In line, GST (EC 2.5.1.18) conjugates GSH and electrophilic substrates, in its active sites, thus metabolizing xenobiotics (especially, herbicides and 
pharmaceutically active compounds) and transport them into vacuoles $[163,164]$. It is also involved in peroxide breakdown, hormone biosynthesis, and stress signaling as well as accelerating GPX activity [165,166]. Moreover, TRX (EC 1.8.1.9), having different isoforms $(f, m, h, s, o, x, y$, and $z$ ), contain an active redox site (WCG/PPC), which reduces disulfide bonds into dithiol by $\mathrm{H}_{2} \mathrm{O}_{2}$ and regulate the target proteins faster than GSH or dithiothreitol [167]. Among the isoforms, TRXx and TRX $y$ can regulate redox homeostasis in chloroplast by reducing 2-Cysteine (Cys) PRX, whereas in mitochondria, TRXo1 participates with PRX and sulfiredoxin to activate antioxidant defense [168]. Another antioxidant enzyme, the thiol-based PRX (EC 1.11. 1.15), exhibits POX-like activity neutralizing peroxides $\left(\mathrm{H}_{2} \mathrm{O}_{2}\right.$ and $\mathrm{ROOH}$ ) in the cytosol, chloroplasts, mitochondria, and nucleus of plant cells [169,170]. The PRXs are thiol-dependent (GSH or any other thiol), playing a vital role in ROS regulation due to the capability of reducing various organic and inorganic peroxides (Figure 5 and Table 2) [171].

\section{Antioxidant Defense in Plants under Abiotic Stress: Recent Approaches}

Plants activate their antioxidant defense system to mitigate the adverse effects of oxidative stress. However, antioxidant defense capacity varies among plant species and genotypes, as well as stress types and duration (Table 3). Moreover, different approaches to enhance plant antioxidant defense have also been revealed (Table 3 ).

\subsection{Antioxidant Defense in Plants under Salinity}

Regulation of antioxidant machinery ameliorates the effects of salt stress in plants, as reported in many plant studies (Table 3). Researchers have reported that differential activities of antioxidant enzymes vary according to salinity extent, exposure time, and the developmental stages of plants [172,173]. For instance, Vighi et al. [174] observed differential response in salt-tolerant (BRS Bojuru) rice cultivar compared with salt-sensitive (BRS Pampa) one and concluded that OsAPX3, OsGR2, OsGR3, and OsSOD3-Cu/Zn genes were the basic differential markers between tolerant and sensitive rice genotypes. In another study, Zeeshan et al. [175] compared wheat (salt-tolerant cv. Suntop and -sensitive Sunmate) and barley (salt-tolerant cv. CM72) cultivars and concluded that higher activities of antioxidants (SOD, peroxidase; POD, APX, GR, and CAT) are strongly correlated with the higher salt tolerance depicting a clear role of antioxidant activities in mitigation of salt-induced oxidative stress. Similarly, Alzahrani et al. [124] found increased SOD, CAT, GR, and AsA levels in faba bean genotypes, when $\mathrm{H}_{2} \mathrm{O}_{2}$ increased above $90 \%$ under salinity stress, confirming the regulation of antioxidant response under salt stress and its mitigation. The regulation of antioxidant activities through the use of either chemical or natural protectants under salt stress has also confirmed the role of plant antioxidant machinery in ameliorating stresses such as salinity [176-178]. For instance, Alsahli et al. [179] found that a 2-fold increase in SOD, CAT, and APX activity decreased 3-fold $\mathrm{H}_{2} \mathrm{O}_{2}$ in salt-stressed wheat by salicylic acid (SA) application compared with untreated control plants. Similarly, the combined application of jasmonic acid (JA) and humic acid also increased APX activity, resulting in salinity tolerance in sorghum [180], while exogenous application of polyamines regulated sour orange antioxidant responses under salinity stress conditions [181]. Nitrogen supplementation is also reported to increase the antioxidant (SOD, CAT, APX, GR, MDHAR, DHAR activities and the biosynthesis of AsA and GSH) levels with declining 2.5-fold $\mathrm{H}_{2} \mathrm{O}_{2}$ and 1.7-fold $\mathrm{O}_{2}{ }^{--}$generation in wheat under $100 \mathrm{mM} \mathrm{NaCl}$ stress [182]. Moreover, silicon ( $\mathrm{Si}$ ) supplementation also increased antioxidant activities and decreased ROS, MDA, and EL levels in mung bean under salinity [74]. Chung et al. [183] reported Si-induced upregulation of antioxidant enzyme genes GmCAT1 (by 3-fold), GmCAT2 (by 4-fold), and GmAPX1 (by 8-fold), leading to salt stress tolerance in soybean after $6 \mathrm{~h}$ of stress exposure. Similar transcriptional regulation of antioxidant enzyme transcript levels ( $C A P X, C A T, G R$, and MnSOD) decreased 0.4-fold $\mathrm{H}_{2} \mathrm{O}_{2}$ and 3.9-fold $\mathrm{NO}$ in hydrogen sulfide $\left(\mathrm{H}_{2} \mathrm{~S}\right)$-primed strawberry plants under $\mathrm{NaCl}$ stress in a hydroponic setup [184]. Santander et al. [185] reported that arbuscular mycorrhizae-induced increased SOD, CAT, and APX activities in 40 and $80 \mathrm{mM} \mathrm{NaCl}$-stressed cucumber. Moreover, Moringa oleifera leaf extract (6\%) or Glycyrrhiza glabra root extract mitigates salt stress by upregulating antioxidants in 
wheat and bean (P. vulgaris) [186,187]. Finally, supplementation of fungicidal compound penconazole (15 $\mathrm{mg} \mathrm{L}^{-1}$ ) regulated SOD, CAT, POX, and PPO activity to mitigate the negative impact of salinity in sesame (S. indicum) [188]. From the above-discussed examples, the overall influence of plant antioxidant system in the mitigation of salt stress and associated oxidative stress conditions is clear and an immensely important factor to be aware of.

\subsection{Antioxidant Defense in Plants under Water Deficit and Simulated Drought}

Activating antioxidant defense as an adaptive mechanism against drought stress was reported in different plants (Table 3) $[83,89,90]$. Nahar et al. [91] demonstrated decreased AsA/DHA and GSH/GSSG ratio with increased APX, GR, GPX, and GST activities in drought-exposed V. radiate seedlings compared with control, which contributed in drought-induced oxidative damage tolerance. Akram et al. [189] compared the performances of two canola cultivars B. napus (cv. Dunkeld and Cyclone) exposed to water deficit condition (60\% FC, $21 \mathrm{~d}$ ) and found increased total phenolic contents as well as upregulated CAT and POD activities in both cultivars. When studying two Sorghum bicolor L. cultivars (M-81E (tolerant) and Roma (sensitive)), Guo et al. [190] found that drought stress increased $28.9 \%$ and $54.9 \% \mathrm{H}_{2} \mathrm{O}_{2}$ in $\mathrm{M}-81 \mathrm{E}$ and Roma, respectively, relative to control, when SOD activity increased 1.6 and 1.1 times and APX activity increased 1.7 and 0.9 times, respectively, to improve drought tolerance. Yet, inhibited CAT activity but enhanced GPX activity was found under drought stress (irrigation stopped at 10 days after sowing, $11 \mathrm{~d}$ ) in Triticum aestivum cv. Sakha-94 [191]. Meanwhile, a comparative study with Zea mays cv. Xida 889 and Xida 319 subjected to drought ( $50 \%$ FC, 15 d) reported that GSH content increased by $17 \%$ and $28 \%$ in Xida 319 and Xida 889 , respectively, compared with the well-watered condition [150]. In addition, Rady et al. [95] observed higher $\mathrm{H}_{2} \mathrm{O}_{2}(26.2 \%)$ and $\mathrm{O}_{2}{ }^{\bullet-}(51 \%)$ generation with enhanced SOD, CAT, and APX activities by $110 \%$, $66 \%$, and $77 \%$, respectively, as well as significantly increased AsA, GSH, and $\alpha$-tocopherol content in S. lycopersicum cv. Login 935 exposed to drought stress (60\% FC, $20 \mathrm{~d})$, which indicates increased antioxidant capacity to tolerate drought-induced oxidative stress. Improved tolerance against drought stress through the regulation of the antioxidant apparatus has also been shown in a number of chemical priming approaches, such as that of Antoniou et al. [130] where pretreatment of M. sativa plants with melatonin resulted in increased CAT activity and lowered $\mathrm{H}_{2} \mathrm{O}_{2}$ content compared with unprimed, drought-stressed plants. Similarly, the employment of nitric oxide and hydrogen sulfide aspirin (NOSH-aspirin) leads to improved performance in M. sativa plants under severe drought stress through the regulation of CAT and SOD activity, as well as $c A P X, C u / Z n S O D$, and FeSOD transcripts [192].

\subsection{Antioxidant Defense in Plants under Toxic Metals/Metalloids}

Metals/metalloids toxicity tolerance is positively correlated with improved antioxidant activities for ROS detoxification and metal chelation (Table 3) [68,193]. Among major antioxidants, GST assists GSH to reduce metals/metalloids toxicity by conjugating with them [166]. Additionally, GSH works as a cytosolic precursor of phytochelatins (PC), which bind the metals and facilitates the compound transport into cell vacuole by catalyzing the shuttle of metal ions and other xenobiotics $[9,194]$. Movement of cytosolic metals/metalloids ions into the vacuole in inert form reduces cellular toxicity [68]. Moreover, both GST and GSH contribute in the accumulation of some flavonoids (anthocyanin), which also act as metal binder and may use the same pathway to be accumulated into the vacuole $[195,196]$. Hasanuzzaman et al. [98] observed an enhancement in both the GSH and GSSG contents in O. sativa seedlings under $\mathrm{Ni}$ stress $\left(0.25\right.$ and $\left.0.5 \mathrm{mM} \mathrm{NiSO}_{4} \cdot 7 \mathrm{H}_{2} \mathrm{O}\right)$, among which $\mathrm{GSH}$ was further increased, but GSSG declined by exogenous $\mathrm{Si}\left(0.05 \mathrm{mM} \mathrm{Na}_{2} \mathrm{SiO}_{3}\right)$ application signifying the role of $\mathrm{Si}$ in upregulating GSH. Moreover, Ni stress-induced enhancement of SOD, GPX, APX, MDHAR, DHAR, and GR activities, which was further upregulated by Si supplementation that helped to minimize $\mathrm{Ni}$ toxicity. Ahanger et al. [105] reported an increment in GSH and tocopherol content along with SOD, GST, and DHAR activities with higher $\mathrm{H}_{2} \mathrm{O}_{2}(61 \%)$ and $\mathrm{O}_{2}{ }^{\bullet-}(47 \%)$ content in Cd-stressed $\left(100 \mu \mathrm{M} \mathrm{CdCl}_{2}, 20 \mathrm{~d}\right) \mathrm{V}$. angularis seedlings, whereas AsA levels and CAT activity declined. Contrarily, 
SOD, CAT, POX, and GR activities were upregulated with higher content of $\mathrm{H}_{2} \mathrm{O}_{2}(53.45 \%$ and $69.83 \%$, respectively) under Cd stress (50 $\mu \mathrm{M} \mathrm{CdCl}_{2}, 100 \mathrm{~d}$ ) in two Mentha arvensis (cv. Kosi and Kusha) genotypes pointing out the activation of an antioxidant defense system for conferring $\mathrm{Cd}$ toxicity tolerance [106]. The authors also reported a further upregulated antioxidant defense following application of gibberellic acid, triacontanol, or SA. Mahmud et al. [102] measured the AsA, DHA, GSH, and GSSG contents of B. juncea seedlings grown under Cd toxicity (0.5 and $1.0 \mathrm{mM} \mathrm{CdCl}_{2}$, $3 \mathrm{~d}$ ) and found that AsA content along with CAT, MDHAR, DHAR, and GR activities declined in a dose-dependent manner, which was reversed by citric acid (CA, 0.5 and $1.0 \mathrm{mM}$ ) cotreatment. Moreover, CA cotreatment increased GSH content, SOD, APX, and GPX activities, and further assisted in reducing oxidative stress [102]. Lead $(\mathrm{Pb})$ stress $\left(1.0 \mathrm{mM} \mathrm{Pb}\left(\mathrm{NO}_{3}\right)_{2}\right)$ resulted in lower AsA content as well as declined CAT, MDHAR, GR, and GPX activities with increasing $\mathrm{H}_{2} \mathrm{O}_{2}$ content by $41 \%$ and $95 \%$ at mild and severe stress, respectively, in wheat seedlings, which was inversely altered by $1.0 \mathrm{mM}$ of GSH supplementation, thus demonstrating the effect of GSH in activating antioxidant defense system [107]. However, exogenous spermidine assisted in the restoration of AsA and GSH contents, as well as AsA/DHA and GSH/GSSG ratio, together with APX, DHAR, GR, and CAT activity, resulting in lower aluminum ( $\mathrm{Al} ; \mathrm{AlCl}_{3} 0.5 \mathrm{mM}, 48$ and $72 \mathrm{~h}$ )-induced oxidative stress in $V$. radiate seedling [133].

\subsection{Antioxidant Defense in Plants under High Temperature}

Like other abiotic stress factors, the antioxidant defense mechanism is activated to cope with high temperature (HT) stress in plants (Table 3) [113,197], but overall antioxidant capacity differs between species as well as tolerant and sensitive genotypes [9]. According to Kumar et al. [149], the activity of APX and GR was significantly suppressed in sensitive chickpea genotypes (ICC14183 and ICC5912) with increasing almost 2-fold $\mathrm{H}_{2} \mathrm{O}_{2}$ under HT conditions in comparison with tolerant genotypes (ICCV07110 and ICCV92944). Liu et al. [93] reported decreased SOD and CAT activities with corresponding suppressed OsSOD, OsCAT, and OsAPX2 expression, resulting in higher accumulation of $\mathrm{H}_{2} \mathrm{O}_{2}$ (1.27-fold) in germinating rice seeds under HT stress. Sarkar et al. [198] found elevated activity of CAT and POX in wheat genotypes under HT stress $\left(30^{\circ} \mathrm{C}\right)$. In another example, Zandalinas et al. [199] observed increased GSH and AsA content in Carrizo citrange along with enhanced SOD and CAT activity compared with Cleopatra mandarin under HT stress $\left(40^{\circ} \mathrm{C}\right)$. Furthermore, Sarwar et al. [134] pretreated cotton plants with $\mathrm{H}_{2} \mathrm{O}_{2}$ under HT stress and found increased SOD and CAT activity in comparison with unprimed, HT-stressed plants. Similar findings were reported by Christou et al. [20] who showed that strawberry plants pretreated with sodium hydrosulfide (NaHS) under HT stress $\left(42{ }^{\circ} \mathrm{C}, 8 \mathrm{~h}\right.$ ) became more resilient than unprimed, stressed plants, and this was linked with the enhanced transcription of AsA (GDH) and GSH biosynthetic enzymes (GS, GCS), as well as enzymatic antioxidants ( $C A P X, C A T, M n S O D$, and GR).

\subsection{Antioxidant Defense in Plants under Low Temperature}

Plants activate the antioxidant defense system to cope with low temperature (LT) stress as well (Table 3). A 3- and 2-fold increased Cu-ZnSOD and Fe-SOD activities, respectively, to a response of higher $\mathrm{H}_{2} \mathrm{O}_{2}$ and $\mathrm{O}_{2}{ }^{\bullet-}$ production were reported in cucumber (C. sativus cv. Xinyan 4) seedling exposed to LT [15/8 ${ }^{\circ} \mathrm{C}$ day/night, $8 \mathrm{~d}$ ] stress [200]. Moreover, significantly increased CAT activity was observed in Cynodon dactylon, Capsella bursa pastoris, and Citrus reticulata, during LT stress [201-203]. Contrarily, higher APX activity was observed in Jatropha macrocarpa as a response to high $\mathrm{H}_{2} \mathrm{O}_{2}$, which improved LT stress tolerance, whereas reduced APX activity (>6-fold) in J. curcas was linked with increased sensitivity under LT conditions [204]. Cheng et al. [205] experimented with Citrullus lanatus under LT stress $\left(10 / 5^{\circ} \mathrm{C}, 7 \mathrm{~d}\right)$ and observed the activation of the antioxidant defense system, where GSH/GSSG and AsA/DHA ratios increased significantly only a day after treatment compared with control samples. Similarly, Wang et al. [206] observed increased AsA and GSH levels as a response to higher $\mathrm{H}_{2} \mathrm{O}_{2}$ content in transgenic apple seedlings under LT stress $\left(8^{\circ} \mathrm{C}, 12 \mathrm{~h}\right)$. More recently, 
Han et al. [116] exposed 14-d-old rice seedlings to LT $\left(12{ }^{\circ} \mathrm{C}, 6 \mathrm{~d}\right)$ stress and reported higher content of $\mathrm{H}_{2} \mathrm{O}_{2}$ and $\mathrm{O}_{2}{ }^{\bullet-}$ accumulation increased SOD and CAT activity along with enhanced GSH/GSSG ratio.

\subsection{Antioxidant Defense in Plants under Flooding}

Several crop species exhibit their ability to survive under the flooded or WL condition for short or even longer durations by activating antioxidant defense systems (Table 3). Li et al. [207] exposed 18 maize genotypes to WL conditions. After $2 \mathrm{~d}$ of WL stress, $19-57 \%$ higher SOD activity was observed in 12 genotypes, 19.16-106.96\% higher POD activity was found in 13 genotypes, while $26-57 \%$ higher CAT activity was found in only 9 genotypes. Lower AsA but increased GSH and GSSG content along with higher $\mathrm{H}_{2} \mathrm{O}_{2}$ content were observed in sesame seedling under WL stress in a time-dependent manner [121]. However, AsA-GSH cycle enzymes were not regulated in the same manner, showing significantly higher APX and MDHAR activity and lower DHAR and GR activity, during prolonged ( $8 \mathrm{~d}$ ) WL stress [121]. Moreover, Park and Lee [123] recorded higher $\mathrm{H}_{2} \mathrm{O}_{2}$ $(52 \%)$ accumulation increased $91 \%$ higher CAT activity compared with controls in the Antarctic plant D. antarctica exposed to WL $(7 \mathrm{~d})$ conditions. 
Table 3. Antioxidant defense in plants under different abiotic stress factors.

\begin{tabular}{|c|c|c|c|}
\hline Plant Species & Stress Conditions & Antioxidant Defense & References \\
\hline \multicolumn{4}{|c|}{ Salinity } \\
\hline Triticum aestivum & $100 \mathrm{mM} \mathrm{NaCl} ; 20 \mathrm{~d}$ & $\begin{array}{l}\text { Nitrogen supplementations increased the activity of SOD, CAT, GR, MDHAR, } \\
\text { and DHAR by 2-folds and APX 3-folds, respectively, compared to untreated. }\end{array}$ & [182] \\
\hline Nicotiana benthamiana & $150 \mathrm{mM} \mathrm{NaCl} ; 15 \mathrm{~d}$ & Acetylcholine application increased SOD by 1 -fold and POD by 2 -folds. & [208] \\
\hline Solanum lycopersicum & $150 \mathrm{mM} \mathrm{NaCl} ; 5 \mathrm{~d}$ & $\begin{array}{l}\text { Vanillic acid increased AsA/DHA, GSH/GSSG, MDHAR, GR, GST, SOD, } \\
\text { and CAT by } 161 \%, 90 \%, 18 \%, 53 \%, 87 \%, 43 \%, 105 \% \text {, respectively. }\end{array}$ & [209] \\
\hline Medicago sativa & $250 \mathrm{mM} \mathrm{NaCl} ; 2 \mathrm{w}$ & Melatonin increased the activities of CAT, POX, and $\mathrm{Cu} / \mathrm{Zn}-\mathrm{SOD}$. & [210] \\
\hline Cucumis sativus & $150 \mathrm{mM} \mathrm{NaCl} ; 3 \mathrm{~d}$ & $\begin{array}{l}\text { Melatonin increased CAT, SOD, POD, and APX by } 23 \%, 29 \%, 15 \% \text {, and } 16 \% \text {, } \\
\text { respectively. }\end{array}$ & [211] \\
\hline T. aestivum & $100 \mathrm{mM} \mathrm{NaCl} ; 20 \mathrm{~d}$ & $\begin{array}{c}\text { Sodium nitroprusside (SNP) and glucose solely increased Cys and GSH } \\
\text { content by } 86 \% \text { and } 79 \% \text {, and } 19 \% \text { and } 18 \% \text {, respectively, whereas SOD, CAT, } \\
\text { APX, and GR increased by } 75 \% \text { and } 65 \%, 49 \% \text { and } 37 \%, 97 \% \text { and } 57 \% \text {, and } 60 \% \\
\text { and } 57 \% \text {, respectively. } \\
\text { Combined SNP and glucose application increased the activity of these } \\
\text { antioxidant enzymes (SOD, CAT, APX, and GR by } 138 \%, 61 \%, 271 \%, 127 \% \text { and } \\
44 \%, 17 \%, 119 \%, 23 \% \text {, respectively, compared to the control and } \\
\text { glucose-treated plants. }\end{array}$ & [212] \\
\hline C. sativus & $200 \mathrm{mM} \mathrm{NaCl} ; 7 \mathrm{~d}$ & $\begin{array}{l}\mathrm{H}_{2} \mathrm{~S} \text { increased ASA content by } 42.6 \% \text { and GR activity by } 9.1 \% \text {. } \\
\text { Reversed decreased SOD and POD activity. }\end{array}$ & [213] \\
\hline Brassica juncea & $100 \mathrm{mM} \mathrm{NaCl} ; 15 \mathrm{~d}$ & $\begin{array}{l}\text { Nitric oxide increased SOD, CAT, APX, and GR activity by } 91 \%, 33 \%, 114 \% \text {, } \\
\text { and } 49 \% \text {, respectively. }\end{array}$ & [214] \\
\hline \multicolumn{4}{|c|}{ Water Deficit and Simulated Drought } \\
\hline $\begin{array}{l}\text { Zea mays cv. Run Nong 35, Wan } \\
\text { Dan } 13 \text { and Dong Dan } 80\end{array}$ & $\begin{array}{l}\text { Mild drought }(80 \% \text { FC), moderate } \\
\text { drought }(60 \% \mathrm{FC}) \text {, and severe } \\
\text { drought }(40 \% \mathrm{FC})\end{array}$ & $\begin{array}{l}\text { Increased activities of APX, MDHAR, and DHAR by } 24 \%, 13 \% \text {, and } 29 \% \text { in } \\
\text { Dong Dan. } 80 \% \text { and } 16 \%, 11 \% \text {, and } 10 \% \text { in Wan Dan } 13 \text {, respectively, under } \\
\text { severe drought. } \\
\text { Higher SOD activity as well as AsA and DHA contents under moderate and } \\
\text { severe drought in both maize hybrids. }\end{array}$ & [129] \\
\hline Glycine max and G. tomentella & Water deficit, flowering stage, $12 \mathrm{~d}$ & $\begin{array}{c}\text { A substantially increased SOD and GR enzymes activities with the highest } \\
\text { value during 8th day of stress treatment in G. max. } \\
\text { A gradual increase in GR activity till the end of drought treatment was } \\
\text { observed in G. tomentella. }\end{array}$ & [215] \\
\hline
\end{tabular}


Table 3. Cont

\begin{tabular}{|c|c|c|c|}
\hline Plant Species & Stress Conditions & Antioxidant Defense & References \\
\hline Brassica napus cv. Binasarisha-3 & $\begin{array}{c}\text { Osmotic stress ( } 10 \% \text { and } 20 \% \text { PEG), } \\
48 \mathrm{~h}\end{array}$ & $\begin{array}{l}\text { MDHAR activity was higher under 10\% PEG. } \\
\text { DHAR activity increased under both stress level. } \\
\text { GR and GST activity was higher by } 26 \% \text { and } 23 \% \text { and } 25 \% \text { and } 31 \% \text { at both } \\
\text { stress level, respectively. }\end{array}$ & [89] \\
\hline $\begin{array}{l}\text { Phaseolus vulgaris cv. Bn-150 } \\
\text { (drought-tolerant) and Bn-16 } \\
\quad \text { (drought-sensitive) }\end{array}$ & $\begin{array}{l}\text { Moderate drought }(50 \% \mathrm{FC}) \text { and } \\
\text { severe drought }(0 \% \mathrm{FC}), 14 \mathrm{~d}\end{array}$ & $\begin{array}{l}\text { Significantly increased total phenolic contents of } \mathrm{Bn}-150 \text { by } 223 \% \text { and } 265 \% \text {, } \\
\text { respectively, under moderate and severe drought. } \\
\text { SOD, CAT, APX, and GR activities were increased in tolerant genotypes } \\
\text { (Bn-150) than the sensitive one }(\mathrm{Bn}-16) \text {. }\end{array}$ & [97] \\
\hline $\begin{array}{l}\text { Vigna radiata } \\
\text { cv. BARI Mung-2 }\end{array}$ & Osmotic stress (5\% PEG), $48 \mathrm{~h}$. & $\begin{array}{c}\text { Decreased AsA/DHA ratio by } 54 \% \text {. } \\
\text { Increased APX and GR by } 20 \% \text { and } 42 \% \text {, respectively. } \\
\text { Reduced CAT and MDHAR activity by } 13 \% \text { and } 26 \% \text {, respectively. }\end{array}$ & [91] \\
\hline B. napus cv. Binasarisha-3 & $\begin{array}{c}\text { Osmotic stress ( } 10 \% \text { and } 20 \% \text { PEG), } \\
48 \mathrm{~h}\end{array}$ & $\begin{array}{l}\text { Moderate stress increased AsA content, GPX, and GST activity but reduced } \\
\text { CAT activity, whereas severe stress enhanced APX activity but reduced } \\
\text { MDHAR, DHAR, and GR activities. } \\
\text { Both levels of stress increased GSH and GSSG contents by } 31 \% \text { and } 26 \% \text {; and } \\
\quad 83 \% \text { and } 225 \% \text {, respectively, compared to control. }\end{array}$ & [90] \\
\hline B. rapa cv. BARI Sharisha- 15 & Osmotic stress (20\% PEG), $2 \mathrm{~d}$ & $\begin{array}{l}\text { AsA and GSH contents increased by } 10 \% \text { and } 72 \% \text {, respectively. } \\
\text { APX, GR, CAT, and GPX activity increased by } 23 \%, 81 \%, 29 \% \text {, and } 26 \% \text {, } \\
\text { respectively. }\end{array}$ & [132] \\
\hline $\begin{array}{l}\text { Z. mays cv. Xida } 889 \text { and Xida } \\
319\end{array}$ & Drought (50\% FC), $15 \mathrm{~d}$ & $\begin{array}{l}\text { SOD and total antioxidant activities increased, whereas CAT, APX, and POD } \\
\text { activity declined. } \\
\text { GSH content increased by } 17 \% \text { and } 28 \% \text { in Xida } 319 \text { and Xida } 889 \text {, respectively, } \\
\text { compared to control. }\end{array}$ & [150] \\
\hline $\begin{array}{c}\text { Oryza sativa var. japonica cv. } \\
\text { Nipponbare }\end{array}$ & Osmotic stress (20\% PEG-6000), $5 \mathrm{~d}$ & $\begin{array}{l}\text { Decreased SOD, APX, and CAT activities, but POD activity increased by } 59 \% \\
\text { compared to control. }\end{array}$ & [93] \\
\hline S. lycopersicum cv. Login 935 & Drought stress (60\% FC), $20 \mathrm{~d}$ & $\begin{array}{c}\text { Enhanced SOD, CAT, and APX activities by } 110 \%, 66 \% \text {, and } 77 \% \text {, respectively. } \\
\text { Increased AsA, GSH, and } \alpha \text { tocopherol contents by } 81 \%, 93 \% \text {, and } 103 \% \text {, } \\
\text { respectively. }\end{array}$ & [95] \\
\hline G. $\max$ & $\begin{array}{c}\text { Osmotic stress }(5 \%, 10 \% \text {, and } 15 \% \\
\text { PEG), } 3 \mathrm{w}\end{array}$ & $\begin{array}{c}\text { Highest activities of CAT, APX, and PPO were observed at mild osmotic stress } \\
\text { (5\% PEG), whereas increased SOD and POX activities were found at severe } \\
\text { osmotic stress (15\% PEG). } \\
\text { Total phenol and tocopherol contents increased by } 51 \%, 32 \% \text {, and } 44 \% \text {, } \\
\text { and } 26 \%, 26 \% \text {, and } 21 \% \text { at three levels of osmotic stress intensities, } \\
\text { respectively, compared to control. }\end{array}$ & [94] \\
\hline
\end{tabular}


Table 3. Cont

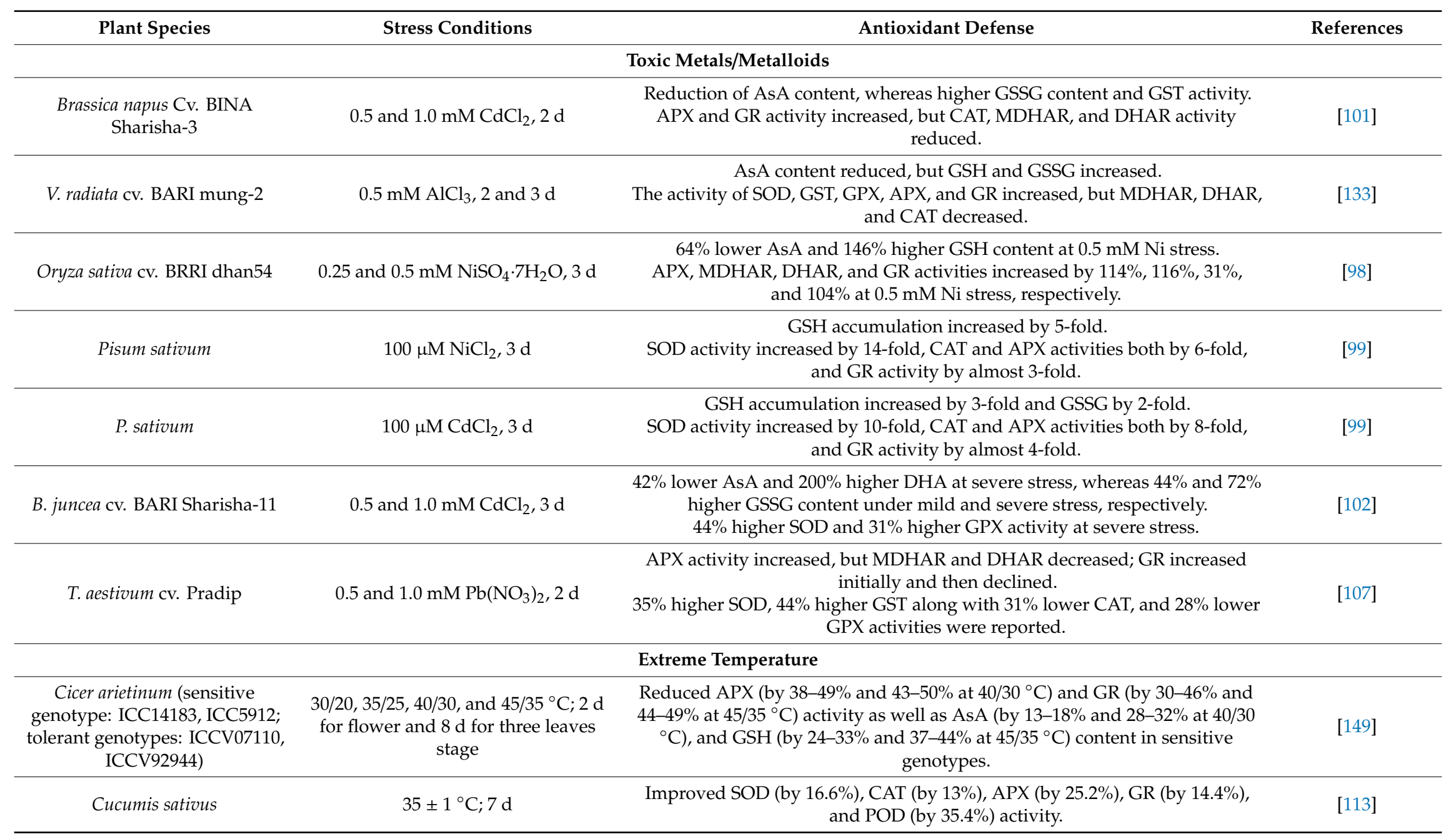


Table 3. Cont

\begin{tabular}{|c|c|c|c|}
\hline Plant Species & Stress Conditions & Antioxidant Defense & References \\
\hline Sorghum bicolor & $\begin{array}{l}36 / 26 \text { and } 39 / 29^{\circ} \mathrm{C} \text {; until } 7 \mathrm{~d} \text { after full } \\
\text { anthesis }\end{array}$ & $\begin{array}{c}\text { In pollen, decreased the SOD (58-87\%), CAT (44-56\%), and POX (36-60\%) } \\
\text { activity. } \\
\text { In pistil, decreased the SOD ( } 59-77 \%) \text {, CAT ( } 35-60 \%) \text {, and POX (42-78\%) } \\
\text { activity. }\end{array}$ & [114] \\
\hline Gossypium hirsutum & $45 / 30 \pm 2{ }^{\circ} \mathrm{C} ; 120 \mathrm{~d}$ & Enhanced SOD and CAT activity. & [134] \\
\hline O. sativa & $38^{\circ} \mathrm{C} ; 5 \mathrm{~d}$ & $\begin{array}{l}\text { Decreased the activity of SOD and CAT. } \\
\text { Enhanced POD (by } 32.1 \% \text { ) activity. }\end{array}$ & [93] \\
\hline O. sativa cv. DM You 6188 & $12{ }^{\circ} \mathrm{C} ; 6 \mathrm{~d}$ & Enhanced SOD (by 1.4\%), CAT (by 1.58\%), and GSH/GSSG (by 2.42-fold). & [116] \\
\hline Calendula officinalis & $4^{\circ} \mathrm{C} ; 24,48,72,96$, and $120 \mathrm{~h}$ & Elevated GR $(161 \%)$, SOD $(46 \%)$, and APX (82\%) activity at $120 \mathrm{~h}$. & [216] \\
\hline Capsella bursa-pastoris & $10^{\circ} \mathrm{C} ; 24,48,72,96$, and $120 \mathrm{~h}$ & Elevated GR $(70 \%)$, POD $(79 \%)$, and CAT $(70 \%)$ activity at $120 \mathrm{~h}$. & [202] \\
\hline Citrus reticulata & $1,-1$, and $-3{ }^{\circ} \mathrm{C} ; 3 \mathrm{~h}$ & Enhanced CAT (1.35-fold) and APX (2-fold) activities. & [203] \\
\hline Vitis vinifera & $5^{\circ} \mathrm{C} ; 6,12,24,48$, and $72 \mathrm{~h}$ & $\begin{array}{l}\text { Elevated GR }(20.26 \%), \text { DHAR }(7.64 \%) \text {, and MDHAR }(16.60 \%) \text { activities with } \\
\text { increased AsA }(12.13 \%), \text { DHA }(7.89 \%) \text {, and GSH }(56.09 \%) \text { contents. }\end{array}$ & [217] \\
\hline \multicolumn{4}{|c|}{ Waterlogging } \\
\hline S. bicolor cv. JN01 and JZ31 & Waterlogged soil, $12 \mathrm{~d}$ & $\begin{array}{l}\text { Increased SOD (by 1.38- and 1.5-fold) and CAT (by 1.43- and 1.36-fold) in JN01 } \\
\text { and JZ31, respectively. }\end{array}$ & [120] \\
\hline $\begin{array}{l}\text { Hordeum vulgare cvs. TF57 and } \\
\text { TF58 }\end{array}$ & Waterlogged soil, $21 \mathrm{~d}$ & $\begin{array}{l}\text { SOD, POD, and CAT activities increased in both WL-sensitive TF57 and } \\
\text { WL-tolerant TF58 genotype. }\end{array}$ & [137] \\
\hline S. lycopersicum cv. Roma & Waterlogged soil, $15 \mathrm{~d}$ & $\begin{array}{l}\text { AsA content reduced by } 31 \% \text {. } \\
\text { SOD, CAT, and POD activities increased by } 7 \%, 33 \% \text {, and } 57 \% \text {, respectively, } \\
\text { compared with control samples. }\end{array}$ & [122] \\
\hline Deschampsia antarctica & Waterlogged soil, $7 \mathrm{~d}$ & Increment of CAT activity by $91 \%$. & [123] \\
\hline Sesamum indicum cv. BARI Til-4 & Waterlogged soil, 2, 4, 6, and $8 \mathrm{~d}$ & $\begin{array}{l}\text { GSH and GSSG increased by } 45 \% \text { and } 150 \% \text {, respectively, whereas AsA } \\
\text { content decreased by } 38 \% \text { after } 8 \mathrm{~d} \text { WL. } \\
\text { APX and MDHAR activity increased by } 61 \% \text { and } 55 \% \text {, but DHAR and GR } \\
\text { activity reduced by } 59 \% \text { and } 23 \% \text {, respectively, after } 8 \mathrm{~d} \text { WL. }\end{array}$ & [121] \\
\hline
\end{tabular}




\section{Revisiting ROS Signaling in Plant Defense}

Excess ROS are generated under abiotic stress owing to the disturbance of different metabolic functions and physiological disorders [5]. The antioxidant defense pathways such as the AsA-GSH pathway require energy in the form of $\mathrm{NADPH}$, and once this energy is depleted, these pathways would be incapable of avoiding ROS toxicity $[5,218]$. However, the functions of ROS (especially $\mathrm{H}_{2} \mathrm{O}_{2}$ ) in plant responses to stresses came into the spotlight at the end of the 20th and the beginning of the 21st century. Few groups of scientists recognized $\mathrm{H}_{2} \mathrm{O}_{2}$ as a signaling molecule, which leads to acclimation processes and confers tolerance under different biotic and abiotic stresses [219,220]. Reactive oxygen species generated in the chloroplast during stress might divert electrons from the photosynthetic machinery preventing overload of the antenna and subsequent damage. Reactive oxygen species also protect mitochondria in a similar way $[5,221]$. Cell wall peroxidase might contribute to ROS generation towards signaling where $\mathrm{H}_{2} \mathrm{O}_{2}$ utilizes $\mathrm{Ca}^{2+}$ and MAPK pathway as a downstream signaling cascade. Moreover, plant hormones, especially ethylene (ET) and abscisic acid (ABA), are involved with stress responses via cross-talk with ROS and enhance stress tolerance, which confirms the dual role of ROS under stress condition [222]. Besides signal transduction and interaction with hormones, ROS can also regulate metabolic fluxes under abiotic stress conditions, which jointly control plant acclimation processes where redox reactions control transcription and translation of stress acclimation proteins and enzymes, ultimately protecting plant cells from damage [5,11]. Moreover, $\mathrm{H}_{2} \mathrm{O}_{2}$ modulates $\mathrm{NO}$ and $\mathrm{Ca}^{2+}$ signaling pathways, which control plant growth and development, as well as other cellular and physiological responses under diverse abiotic stresses [223,224]. As endogenous $\mathrm{H}_{2} \mathrm{O}_{2}$ is involved in increasing tolerance against abiotic stress, exogenous application of $\mathrm{H}_{2} \mathrm{O}_{2}$ is gaining increasing attention and has largely proved its efficacy $[13,18,22,225]$. In Table 4 , we have listed some key reports dealing with the effect of $\mathrm{H}_{2} \mathrm{O}_{2}$ treatment under different abiotic stress conditions.

Moreover, ROS collaborate with RNS, RSS, and RCS under stress conditions and work jointly in signal transduction pathways $[23,226]$. Cellular antioxidant levels might be influenced to alter ROS generation and contribute to signaling [227]. On the other hand, RSS influence the manufacture, perception, and further signaling of ROS and RNS [226], while RCS act downstream of ROS as signal mediators under a variety of stress situations [228]. Therefore, the interacting role among ROS, RNS, RSS, and RCS is discussed in the following section. 
Table 4. Effect of exogenous $\mathrm{H}_{2} \mathrm{O}_{2}$ in plants under different abiotic stress factors.

\begin{tabular}{|c|c|c|c|c|}
\hline Plant Species & Stress Condition & $\mathrm{H}_{2} \mathrm{O}_{2}$ Treatments & Positive Effects & References \\
\hline $\begin{array}{c}\text { Triticum aestivum cv. Zhengmai } \\
\text { No. } 004\end{array}$ & $150 \mathrm{mM} \mathrm{NaCl} ; 2 \mathrm{~d}$ & Cotreatment; $0.05 \mu \mathrm{M}, 2 \mathrm{~d}$ & $\begin{array}{l}\text { Decreased MDA content and } \mathrm{O}_{2}{ }^{\bullet-} \text { generation. } \\
\text { Increased GSH and carotene content by } 21 \% \text { and } 33 \% \text {, } \\
\text { respectively. } \\
\text { Increased SOD, POD, CAT, and APX activity. } \\
\text { Increased growth and biomass. }\end{array}$ & [229] \\
\hline $\begin{array}{l}\text { Cucumis sativus cv. } \\
\text { Jinchun no. } 4 \text { and Lvfeng no. } 6\end{array}$ & $\begin{array}{l}\text { Osmotic stress; (10\% PEG 6000); } \\
2 \mathrm{~d}\end{array}$ & $\begin{array}{l}\text { Pretreatment as spraying; } \\
1.5 \mathrm{mM}\end{array}$ & $\begin{array}{c}\text { Decreased MDA and } \mathrm{H}_{2} \mathrm{O}_{2} \text { content. } \\
\text { Increased AsA and GSH content. } \\
\text { Increased activity of GPX, CAT, APX, GR, MDHAR, } \\
\text { and DHAR. }\end{array}$ & [230] \\
\hline C. sativus cv. Jinchun no. 4 & $\begin{array}{l}\text { Low light; } 100 \mathrm{~mol} \mathrm{~m}^{-2} \mathrm{~s}^{-1} \text {; } \\
\qquad 144 \mathrm{~h}\end{array}$ & $\begin{array}{l}\text { Pretreatment as spraying; } \\
\qquad 1.5 \mathrm{mM}\end{array}$ & $\begin{array}{c}\text { Decreased } \mathrm{O}_{2}^{\bullet-}, \mathrm{H}_{2} \mathrm{O}_{2} \text {, and MDA content. } \\
\text { Increased CAT, SOD, APX, GR, MDHAR, and DHAR } \\
\text { activity. }\end{array}$ & [231] \\
\hline $\begin{array}{l}\text { Vigna radiata L. Wilczek) cv. } \\
\text { SML-668 }\end{array}$ & $\begin{array}{l}\mathrm{Cu},\left(\mathrm{CuSO}_{4} \cdot 5 \mathrm{H}_{2} \mathrm{O}\right) ; 50 \text { and } \\
100 \mathrm{mg} \mathrm{kg}^{-1} \text { of soil. }\end{array}$ & Spraying; $2.5 \mathrm{mM}$ & $\begin{array}{l}\text { Increased relative water content (RWC) and SPAD } \\
\text { value. } \\
\text { Increased Pro content. } \\
\text { Enhanced activity of SOD and CAT. } \\
\text { Increased growth. }\end{array}$ & [16] \\
\hline Glycine max cv. Merrill 537 & $\begin{array}{l}\text { Drought; withholding irrigation, } \\
\qquad 4 \text { and } 7 \mathrm{~d}\end{array}$ & Foliar spray; $1 \mathrm{mM}, 3 \mathrm{~d}$ & $\begin{array}{l}\text { Improved water status, pigment content, } \\
\text { and alleviated lipid peroxidation. } \\
\text { Decreased MDA and } \mathrm{H}_{2} \mathrm{O}_{2} \text { content. } \\
\text { Increased activity of SOD (by } 93 \% \text { and } 190 \% \text { ), CAT (by } \\
49 \% \text { and } 120 \% \text { ), APX (by } 106 \% \text { and } 194 \% \text { ), and GR (by } \\
31 \% \text { and } 229 \% \text { ) on day } 4 \text { and } 7 \text { of the drought period, } \\
\text { respectively, over control. }\end{array}$ & [17] \\
\hline C. sativus L. & Drought; $60 \pm 5 \%$ FC & $\begin{array}{l}\text { Spraying; } 1.5 \mathrm{mM} \\
\left(100 \mathrm{~mL} \mathrm{pot}^{-1}\right)\end{array}$ & $\begin{array}{c}\text { Decreased MDA content and } \operatorname{ROS}\left(\mathrm{O}_{2}{ }^{\bullet-}, \mathrm{H}_{2} \mathrm{O}_{2}\right) \\
\text { generation. } \\
\text { Increased activity of SOD and POD. } \\
\text { Increased soluble sugar and proline content. } \\
\text { Increased chl and RWC. }\end{array}$ & [18] \\
\hline
\end{tabular}


Table 4. Cont

\begin{tabular}{|c|c|c|c|c|}
\hline Plant Species & Stress Condition & $\mathrm{H}_{2} \mathrm{O}_{2}$ Treatments & Positive Effects & References \\
\hline Brassica napus cv. Binasarisha-3 & $\begin{array}{c}\mathrm{Cd} ; 0.5 \mathrm{mM} \text { (mild) and } 1.0 \mathrm{mM} \\
\text { (severe) } \mathrm{CdCl}_{2} ; 2 \mathrm{~d}\end{array}$ & Pretreatment; $50 \mu \mathrm{M}, 24 \mathrm{~h}$ & $\begin{array}{l}\text { Decreased MDA content (by 23\% and 25\%) under both } \\
\text { Cd toxicity levels, respectively. } \\
\text { Decreased } \mathrm{H}_{2} \mathrm{O}_{2} \text { content. } \\
\text { Increased AsA (by } 32 \% \text { and } 30 \% \text { ); GSH content (by } \\
38 \% \text { and } 25 \% \text { ) under both Cd stresses, respectively. } \\
\text { Enhanced GSH/GSSG ratio. } \\
\text { Increased activity of APX (by } 40 \% \text { and } 39 \% \text { ), DHAR } \\
\text { (by } 77 \% \text { and } 67 \% \text { ), GR (by } 36 \% \text { and } 79 \% \text { ), GST (by } 44 \% \\
\text { and } 43 \% \text { ), CAT (by 79\% and } 47 \% \text { ), and glyoxalase II } \\
\text { (by } 47 \% \text { and } 55 \% \text { ) under both Cd stresses, respectively. } \\
\text { Enhanced GPX activity (by } 40 \% \text { ) under severe stress } \\
\text { and glyoxalase I activity (by 35\%) under mild stress. }\end{array}$ & [22] \\
\hline T. aestivum cv. Fsd-2008 and S-24 & $\begin{array}{l}\text { Drought; withholding irrigation, } \\
\qquad 6 \mathrm{w}\end{array}$ & Seed priming; $1.5 \mathrm{mM}, 16 \mathrm{~h}$ & $\begin{array}{l}\text { Decreased MDA and } \mathrm{H}_{2} \mathrm{O}_{2} \text { content. } \\
\text { Enhanced the activity of SOD, CAT, and POD. } \\
\text { Increased photosynthetic pigments. } \\
\text { Increased GB and Pro content. }\end{array}$ & [14] \\
\hline Oryza sativa cv. BRRI dhan 29 & Osmotic stress (15\% PEG-6000) & Foliar spray; 5 and $10 \mathrm{mM}$ & $\begin{array}{l}\text { Decreased MDA and } \mathrm{H}_{2} \mathrm{O}_{2} \text { content. } \\
\text { Increased activity of } \mathrm{CAT} \text { and GPX. } \\
\text { Protected photosynthetic pigments. }\end{array}$ & [13] \\
\hline
\end{tabular}




\section{Cross-Talk of Reactive Nitrogen, Sulfur, and Carbonyl Species with ROS}

Apart from ROS, other reactive species are produced in plant cells during adverse environmental conditions, including RNS, RSS, and RCS (Figure 6) [146,226,232]. All these reactive species are involved in a molecular cross-talk and have a particular role in cellular signaling cascades [23]. Therefore, the following subsections discuss the intimate relationship among ROS, RNS, RSS, and RCS.

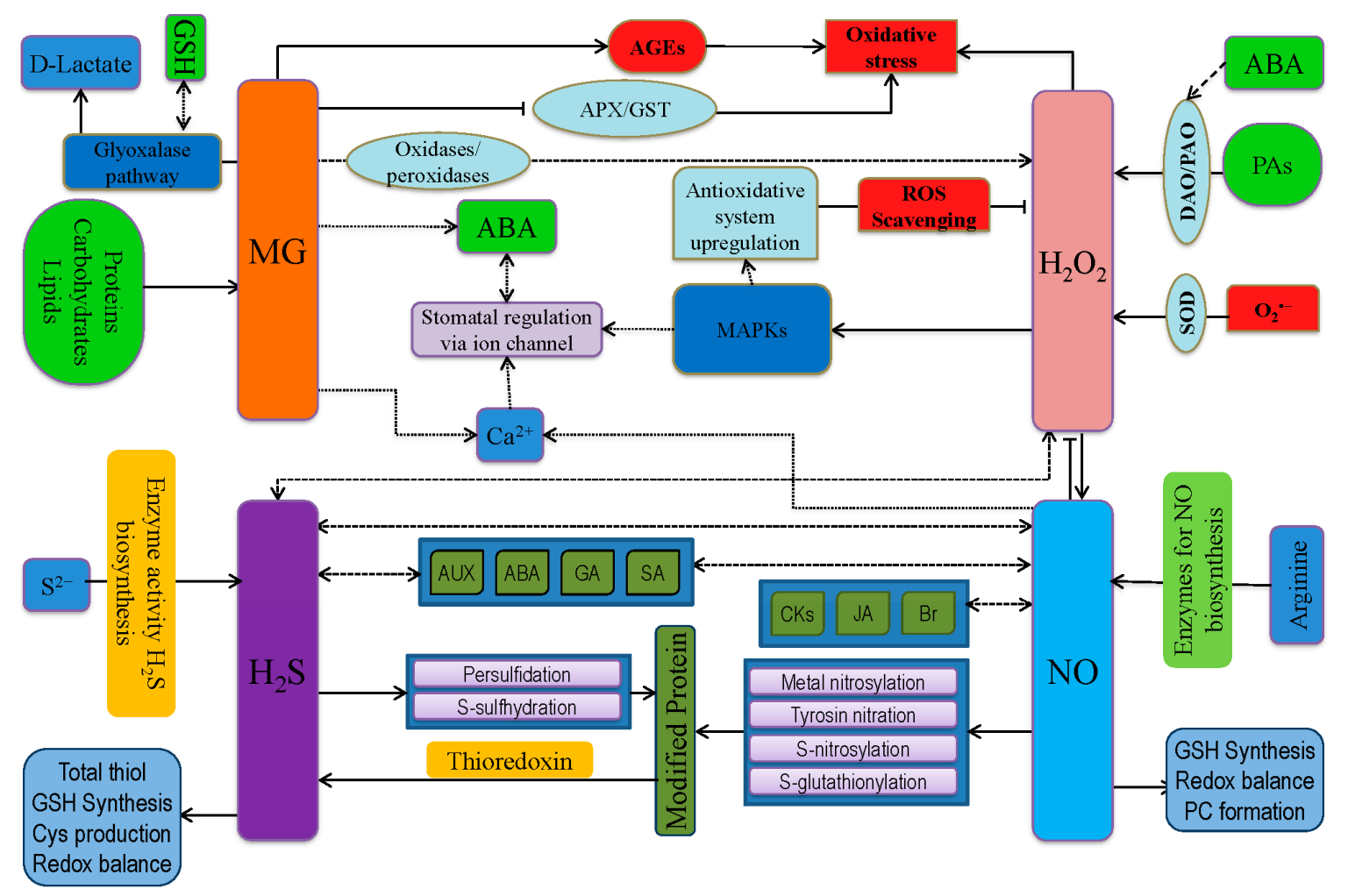

Figure 6. Cross-talk among vital ROS $\left(\mathrm{H}_{2} \mathrm{O}_{2}\right)$, RNS (NO), RSS $\left(\mathrm{H}_{2} \mathrm{~S}\right)$, and RCS (MG) in plant cells for oxidative stress and defense response in plants. APX, ascorbate peroxidase; AUX, auxin; ET, ethylene; ABA, abscisic acid; ROS, reactive oxygen species; GSH, reduced glutathione; JA, jasmonates, MAPKs, mitogen-activated protein kinases; SA, salicylic acid; AEGs, advanced glycation end products; PAs, polyamines; $\mathrm{MG}$, methylglyoxal; $\mathrm{NO}$, nitric oxide; $\mathrm{H}_{2} \mathrm{~S}$, hydrogen sulfide. Dotted lines represent activation/enhancement.

\subsection{Interaction between RNS and ROS}

Nitric oxide (NO) is considered to be the most important RNS in plants and is considered as one of three gasotransmitter molecules (Figure 6) [233,234]. During abiotic stress, ROS is overproduced, resulting in enhanced NO generation primarily by nitrate reductase (NR), indicating an interconnection between ROS and RNS [83,235]. As previously reported, NO generation increased by 8-fold in Arabidopsis following exogenous $\mathrm{H}_{2} \mathrm{O}_{2}$ application and subsequent $\mathrm{NO}$ accumulation activated antioxidant defense system, reduced ROS overgeneration, and reestablished redox balance [83,235]. Contrarily, $\mathrm{H}_{2} \mathrm{O}_{2}$ removal by antioxidants or NADPH oxidase inhibitor prevents NO production [236]. Likely, $\mathrm{Ca}^{2+}$-channel inhibitors (ned-19; 3-(2,3-dichlorophenyl)-1,1-dimethylurea and antimycin A) also inhibit $\mathrm{H}_{2} \mathrm{O}_{2}$-induced $\mathrm{NO}$ production [237]. Moreover, $\mathrm{H}_{2} \mathrm{O}_{2}$ is vital for ABA-mediated NO production [238]. Differently, ABA-induced $\mathrm{H}_{2} \mathrm{O}_{2}$ production is not $\mathrm{NO}$ dependent, which was confirmed by treating with NO donor (sodium nitroprusside, SNP), NO scavenger, and NO synthesis inhibitor. Therefore, $\mathrm{H}_{2} \mathrm{O}_{2}$ actively can modulate NO synthesis, via the NR activity [239]. Importantly, 
both $\mathrm{H}_{2} \mathrm{O}_{2}$ and NO play a vital role in signal transduction as well as phytotoxicity [240]. They also cross-react, generating $\bullet^{\circ} \mathrm{OH}$, which is highly reactive.

$$
\mathrm{H}_{2} \mathrm{O}_{2}+\mathrm{NO} \rightarrow \mathrm{HNO}_{2}+{ }^{\bullet} \mathrm{OH}
$$

Although $\mathrm{H}_{2} \mathrm{O}_{2}$ is detoxified by CAT, APX, and GPX, a small amount might escape, which reacts with $\mathrm{NO}$ and generates damaging ${ }^{\bullet} \mathrm{OH}[240,241]$. In the absence of metal ions, this reaction is one of the most important mechanisms for generating ${ }^{\bullet} \mathrm{OH}$, providing new insights for ROS-induced tissue-specific oxidative damage as well as signal transduction guided by $\mathrm{NO}$ and/or $\mathrm{H}_{2} \mathrm{O}_{2}$ [240]. Under abiotic stress conditions, a number of ROS and RNS, e.g., ${ }^{1} \mathrm{O}_{2}$ and $\mathrm{ONOO}^{-}$might form, leading to oxidative damage [242]. On the other hand, $\mathrm{O}_{2}{ }^{--}$reacts with $\mathrm{NO}$ producing a powerful oxidant, peroxynitrite $\left(\mathrm{ONOO}^{-}\right)$, which participates in the post-translational modification (PTM) of tyrosine nitration of proteins $[243,244]$. In peroxisomes, $S$-nitrosylation inhibits the functioning of glycolate oxidase, CAT, and it can regulate $\mathrm{H}_{2} \mathrm{O}_{2}$ levels at the cellular level [245], whereas, the generated $\mathrm{ONOO}^{-}$molecule cause tyrosine nitration and nitrosative alteration in plants. In addition, the proteomic evaluation showed peroxisomal NADH-dependent hydroxypyruvate reductase, which is dysfunctioned by peroxynitrite through nitration [50]. Therefore, it could be concluded that the cross-talk among the ROS and RNS leads to several damaging or signaling episodes where many factors participate for building a complex network of ROS/RNS.

\subsection{Interaction between RSS and ROS}

Sulfur (S) is the fourth major essential plant nutrient and a structural component for secondary sulfur compounds, such as polysulfides, glucosinolates, PC, thiols, GSH, S-nitrosoglutathione (GSNO), and sulfolipids (Figure 6) [144,234]. Generally, RSS is sometimes called second-generation reactive species as they are formed from the reaction between $S$ and ROS [246]. Interaction of ROS with thiols produces sulfenic acid (R-SOH), further to disulfides, which can donate electrons [246]. Again, R-SOH can undergo PTM (S-glutathionylation and S-cysteinylation), leading to protein stability and proper functioning [247]. Moreover, sulfide-S-oxides can be formed by the decomposition of $S$-nitrosothiols in the presence of high GSH concentration. This mechanism plays vital role in maintaining the redox balance of thiols as well as modulating S-proteins [248]. Meanwhile, the transformation of $\mathrm{R}-\mathrm{SOH}$ to sulfinic acid to sulfonic acid is also possible by the oxidation via ROS [249]. $\mathrm{H}_{2} \mathrm{~S}$ actively interacts with ROS to regulate the plasma membrane antiporter $\left(\mathrm{Na}^{+} / \mathrm{H}^{+}\right)$system [250]. Contrarily, $\mathrm{H}_{2} \mathrm{~S}$ activates enzymatic antioxidants (SOD, CAT, and APX) and enhances GSH content, thus reducing oxidative damages [144,251]. Moreover, $\mathrm{H}_{2} \mathrm{~S}$ is involved in production, perception, and further signal transduction of ROS as well as RNS [234]. As an integral part of the AsA-GSH cycle, redox ratio of GSH:GSSG is important for $\mathrm{H}_{2} \mathrm{O}_{2}$ scavenging, which is influenced by $\mathrm{H}_{2} \mathrm{~S}$ [234,251]. Moreover, AsA content is also manipulated by $\mathrm{H}_{2} \mathrm{~S}$, thus maintaining proper ROS scavenging and acting as a protective molecule at lower cellular concentration [251]. Cysteine plays vital role at the chemical signaling junction of ROS and RSS, where both the molecule regulates signal by Cys-oxidation on proteins. Peroxidation of Cys-S by $\mathrm{H}_{2} \mathrm{O}_{2}$ produces the Cys-peroxide, Cys-SeOH [252], whereas persulfidation with $\mathrm{H}_{2} \mathrm{~S}_{2}$ produces a Cys-persulfide [253]. In addition, Cys-persulfidation prior to protein synthesis has been described [254], but where these Cys-persulfides are targeted yet unidentified as well as the specific regulatory proteins remains to be determined.

\subsection{Interaction between $R C S$ and $R O S$}

There is an intimate relationship between RCS and ROS. Reactive carbonyl species include mainly unsaturated aldehydes and ketones produced during lipid peroxidation, which mediate ROS signals. A dozen different RCS are reported to be produced from various membranes [255]. In addition, if RCS is exogenously added to the plants, a similar response as that induced by ROS could be obtained [255]. Considering these criteria, the damaging/signaling role of RCS has been reported to induce root 
injury, PCD, senescence of leaves and fruits, ABA-mediated stomatal closure, and root response to auxin. Thus, RCS act downstream of ROS as signal transducers during a variety of physiological situations [228]. On the other hand, RCS can modulate antioxidants (CAT, APX, and POD) and thus induce ROS overaccumulation and oxidative stress [256]. It has been demonstrated that RCS-induced ROS generation leads to ABA signaling suggesting ABA-induced $\mathrm{ROS}\left(\mathrm{H}_{2} \mathrm{O}_{2}\right)$ production in the guard cell, which increases RCS levels and modulates the signal for stomatal closure [257]. Among RCS, acrolein and 4-Hydroxy-2(E)-nonenal (HNE) formation is stimulated by ROS very early, but other RCS like crotonaldehyde, (E)-2-pentenal, and (E)-2-hexenal are also induced by ROS signals [258]. Furthermore, auxin signaling can induce ROS and RCS formation leading to lateral root initiation [228].

Kaur et al. [259] reported that the generation of methylglyoxal (MG) under stress could overaccumulate ROS directly or induce advanced glycation end products (AGEs) formation. Reports also suggested that increased $\mathrm{O}_{2}{ }^{\bullet-}$ production is accelerated by MG [260]. Methylglyoxal also induced ABA or methyl jasmonates or NAD(P)H deficit dependent on stress signaling. Like ROS, RCS might modify Cys residues of proteins in a reversible way to regulate their activity, which would be effective at low levels. However, at higher levels, RCS can have deleterious effects on proteins since histidine and lysine residues can also react with RCS to form stable adducts and might mimic ROS signals potentially associated with regulating activities of proteins such as TRx, which can further regulate activities of other target proteins via redox regulation [256]. Reactive carbonyl species can also interact with zinc ion $\left(\mathrm{Zn}^{2+}\right)$ and thus release $\mathrm{Zn}^{2+}$ from proteins affecting transcription factors ( $\mathrm{Zn}$ finger proteins) as well as metabolic and defense enzymes [261]. Therefore, whether RCS could limit the activity of ZnSOD and other antioxidants could be a new area of research. In conclusion, ROS can increase RCS production, with RCS potentially interfering with the antioxidant defense system and exerting oxidative stress. Moreover, RCS can also modulate phytohormone biosynthesis and other signals, thus playing a vital role in constructing a complex ROS/RCS network. Therefore, deeper research should be done in this regard to open a new door of climate-smart crop production.

\section{The Transgenic Approach in Enhancing Antioxidant Defense in Plants}

In the past few decades, transgenic approaches have been widely used to improve plant health under oxidative stress. Thus, transgenic plants can be engineered to enhance stress tolerance and the activities of antioxidant enzymes. An overview of transgenic plants with enhanced activities of antioxidant defense systems under several stresses is presented in Table 5. Kiranmai et al. [262] isolated a MUWRKY3 gene from drought-adapted horse gram and overexpressed it in groundnut. Transgenic plants showed lower MDA, $\mathrm{H}_{2} \mathrm{O}_{2}$, and $\mathrm{O}_{2}{ }^{\bullet-}$ contents and enhanced the activities of SOD by 3 to 5-folds and APX by 3 to 7-folds, resulting in increased drought tolerance. Overexpression of MdATG18a in apple enhanced tolerance to drought stress and increased the activities of CAT and POD by 2-fold in transgenic lines. Results also indicated that stress tolerance was improved due to a high frequency of autophagy and restriction of oxidative damage [263]. Overexpression of Chrysanthemum TF gene, $\operatorname{DgNAC1}$ increased salt tolerance in transgenic plants showing lower accumulation of $\mathrm{MDA}_{2} \mathrm{H}_{2} \mathrm{O}_{2}$, and $\mathrm{O}_{2}{ }^{\bullet-}$, and significantly enhanced the activities of SOD, CAT, and POD [264]. Likewise, PaSOD from Potentilla atrosanguinea and RaAPX from Rheum australe were overexpressed in potato. Transgenic plants demonstrated enhanced activities of SOD and APX in dual transgenic plants (DTP). Superoxide dismutase and APX genes may serve as a positive regulator to increased salt tolerance by the regulation of ROS and lignin biosynthesis signaling pathways in transgenic plants [265]. Transgenic tobacco exhibited tolerance to heavy metals and overexpression of SbMYB15 enhanced the activities of CAT and SOD, also increasing the expression of $\mathrm{MnSOD}$ at $100 \mu \mathrm{M}$ (2-fold) and $300 \mu \mathrm{M}$ (3-fold) of $\mathrm{CdCl}_{2}$, as well as CAT1 by 62- and 9-fold at 100 and $300 \mu \mathrm{M}$ of $\mathrm{CdCl}_{2}$ [266]. In regard to heavy metal tolerance, CaGrx from chickpea was overexpressed in A. thaliana. Transgenic plants showed maximal activities of GRX, GR, GPX, GST, and APX under AsIII and Cr stress compared with controls, whereas CAT, SOD, and MDHAR activities were also significantly increased. Authors suggested that CaGrx can be a suitable candidate gene to overcome metal stresses in other crops [267]. Overexpression of the 
A. thaliana AtDREB1A gene in tomato increased chilling tolerance. Transgenic plants enhanced the activities of SOD by $29 \%$ and CAT by $21 \%$, indicating superior chilling stress tolerance [268]. As another example, overexpression of the potato StSOD1 gene enhanced the activities of SOD, POD, and CAT under cold stress and improved cold tolerance in transgenic plants [269]. Similarly, the overexpression of Chrysanthemum CmSOS1 gene enhances SOD and CAT by $171 \%$ in transgenic plants under WL conditions [270]. 
Table 5. Recent advancements in transgenic approaches to enhance the activities of antioxidant defense systems under abiotic stress conditions. Described studies increased stress tolerance by reducing the damage of oxidative stress and by increasing scavenging of ROS under stressful conditions.

\begin{tabular}{|c|c|c|c|c|c|}
\hline $\begin{array}{c}\text { Stress Condition and } \\
\text { Duration }\end{array}$ & Studied Plant & Source Plant & Gene & $\begin{array}{c}\text { Impact on Antioxidant Defense } \\
\text { Systems }\end{array}$ & References \\
\hline \multicolumn{6}{|c|}{ Salinity } \\
\hline $\begin{array}{l}0,50,100, \text { and } 150 \mathrm{mM} \\
\mathrm{NaCl} ; 7 \text { and } 15 \mathrm{~d}\end{array}$ & Solanum tuberosum & $\begin{array}{l}\text { Potentilla } \\
\text { atrosanguinea and } \\
\text { Rheum australe }\end{array}$ & $P a S O D$ and $R a A P X$ & $\begin{array}{l}\text { Enzyme activities are enhanced in } \\
\text { transgenic plants as of SOD by 2-6-fold } \\
\text { in PaSOD and 1-3-fold in double } \\
\text { transgenic plants }(D T P) \text {; APX by } \\
\text { 5-11-fold in APX and 4-8 fold in DTP. }\end{array}$ & [265] \\
\hline $\begin{array}{c}100,200, \text { and } 400 \mathrm{mM} ; 1,5, \\
10,15 \mathrm{~d}\end{array}$ & Chrysanthemum & $\begin{array}{l}\text { Dendronthema } \\
\text { grandiform }\end{array}$ & $D g N A C 1$ & $\begin{array}{l}\text { Enzyme activities are enhanced in } \\
\text { transgenic plants as of SOD by } 2-, \text { CAT } \\
\text { by } 2-\text {, and POD by } 3 \text {-folds. }\end{array}$ & [264] \\
\hline $\begin{array}{c}150 \mathrm{mM} \mathrm{NaCl} ; 3,6,9,12 \\
\text { and } 24 \mathrm{~h}\end{array}$ & Arabidopsis thaliana & Vitis vinifera & VvWRKY30 & $\begin{array}{c}\text { Enzyme activities are significantly } \\
\text { enhanced in transgenic plants, i.e., POD, } \\
\text { CAT, and SOD. }\end{array}$ & [271] \\
\hline $\begin{array}{l}150 \text { or } 200 \mathrm{mM} \mathrm{NaCl} \text {, till } \\
\text { germination }\end{array}$ & Glycine max & Glycine max & GmMYB84 & $\begin{array}{c}\text { Enzyme activities are significantly } \\
\text { enhanced in transgenic plants, i.e., SOD, } \\
\text { POD, and CAT. }\end{array}$ & [272] \\
\hline \multicolumn{6}{|c|}{ Water Deficit and Simulated Drought } \\
\hline $\begin{array}{l}\text { Osmotic stress (20\% PEG); } \\
1,3,612,24 \text {, and } 48 \mathrm{~h}\end{array}$ & Nicotiana tabacum & Spinacia oleracea & SoCYP85A1 & $\begin{array}{c}\text { Overexpressed lines improve the activity } \\
\text { of POD by } 1.3-1.5 \text { and SOD by } \\
1.36-1.39 \text {-fold }\end{array}$ & [273] \\
\hline $\begin{array}{l}\text { Withholding water for } 14 \\
\text { and } 21 \mathrm{~d}\end{array}$ & Malus domestica & Malus domestica & MdATG18a & $\begin{array}{l}\text { Enzyme activities are enhanced in } \\
\text { transgenic plants as of CAT and POD by } \\
1.57-2.05 \text {-fold in overexpressed lines. }\end{array}$ & [263] \\
\hline $\begin{array}{l}\text { Withholding water till the } \\
\text { wilting stage }\end{array}$ & Arachis hypogaea & $\begin{array}{l}\text { Macrotyloma } \\
\text { uniflorum Lam. } \\
\text { Verdc. }\end{array}$ & MuWRKY3 & $\begin{array}{l}\text { Enzyme activities are enhanced in } \\
\text { transgenic plants as of SOD by } 3-5 \text { and } \\
\text { APX by } 3-7-\text { fold }\end{array}$ & [262] \\
\hline $\begin{array}{l}\text { Osmotic stress (15\% PEG); } \\
60 \mathrm{~d}\end{array}$ & N. tabacum & Zea mays & $\mathrm{ZmSO}$ & $\begin{array}{l}\text { Overexpressed lines increase the activity } \\
\text { of GSH } 64 \% \text { and } 88 \% \text {. }\end{array}$ & [274] \\
\hline
\end{tabular}


Table 5. Cont.

\begin{tabular}{|c|c|c|c|c|c|}
\hline $\begin{array}{l}\text { Stress Condition and } \\
\text { Duration }\end{array}$ & Studied Plant & Source Plant & Gene & $\begin{array}{c}\text { Impact on Antioxidant Defense } \\
\text { Systems }\end{array}$ & References \\
\hline $\begin{array}{c}\text { Osmotic stress }(15 \% \text { and } \\
25 \% \text { PEG); } 7 \mathrm{~d}\end{array}$ & A. thaliana & Cicer arietinum & CaMT & $\begin{array}{l}\text { Enzyme activities are enhanced in } \\
\text { transgenic plants as of APX } 488 \% \text {, POD } \\
135 \% \text {, GPX } 134 \% \text {, and GRX } 186 \% \text {. }\end{array}$ & [275] \\
\hline $\begin{array}{l}\text { Withholding water for } 12 \\
\mathrm{~d}\end{array}$ & A. thaliana & Malus prunifolia & $M p D G K 2$ & $\begin{array}{c}\text { Enzyme activities are enhanced in } \\
\text { transgenic plants, i.e., CAT, APX, } \\
\text { and POD. }\end{array}$ & [276] \\
\hline \multicolumn{6}{|c|}{ Toxic Metals/Metalloids } \\
\hline $\begin{array}{c}\mathrm{As}(\mathrm{III})(5 \text { and } 10 \mu \mathrm{M} \\
\left(\mathrm{NaAsO}_{2}\right), \mathrm{As}(\mathrm{V})(50 \text { and } \\
100 \mu \mathrm{M}\left(\mathrm{Na}_{2} \mathrm{HAsO}\right), \mathrm{Cd} \\
\left(30 \text { and } 50 \mu \mathrm{M}\left(\mathrm{CdCl}_{2}\right)\right. \\
\text { and } \mathrm{Cr}\left(\mathrm{K}_{2} \mathrm{Cr}_{2} \mathrm{O} 7\right)\end{array}$ & A. thaliana & Oryza sativa & OsSultr1;1 & $\begin{array}{l}\text { Enzyme activity is enhanced in } \\
\text { transgenic plants, i.e., GSH with As(III) } \\
\text { toxicity. }\end{array}$ & [277] \\
\hline $\begin{array}{c}300 \mu \mathrm{M} \mathrm{CdCl}_{2} \text { and } \\
300 \mu \mathrm{M} \mathrm{NiCl} \cdot 6 \mathrm{H}_{2} \mathrm{O} ; 1,12 \\
24, \text { and } 48 \mathrm{~h}\end{array}$ & N. tabacum & Salicornia brachiate & SbMYB15 & $\begin{array}{l}\text { Enzyme activities are enhanced in } \\
\text { transgenic plants as of CAT and SOD } \\
\text { and also increase the expression of } \\
\mathrm{MnSOD} \text { at } 100 \mu \mathrm{M}(1.69 \text {-fold) and } 300 \\
\mu \mathrm{M}\left(3.2 \text {-fold) of } \mathrm{CdCl}_{2} \text { and } C A T 1 \text { by }\right. \\
62.19 \text { - and } 9.8 \text {-fold at } 100 \text { and } 300 \mu \mathrm{M} \text {. }\end{array}$ & [266] \\
\hline \multicolumn{6}{|c|}{ Extreme Temperature } \\
\hline $\begin{array}{c}45^{\circ} \mathrm{C} ; 0.5,1,2,3,6,9,12 \\
\text { and } 24 \mathrm{~h}\end{array}$ & N. tabacum & Triticum aestivum & TaFBA1 & $\begin{array}{l}\text { Enzyme activities are enhanced in } \\
\text { transgenic plants, i.e., SOD, POD, } \\
\text { and APX, while CAT activity was } \\
\text { decreased under heat stress. }\end{array}$ & [278] \\
\hline $48^{\circ} \mathrm{C} ; 6 \mathrm{~h}$ & M. domestica & M. domestica & MdATG18a & $\begin{array}{l}\text { Enzyme activities are enhanced in } \\
\text { transgenic plants, i.e., SOD, POD, CAT, } \\
\text { AsA, and GSH, whereas a decreased } \\
\text { ratio of GSH/GSSG was reported. }\end{array}$ & [279] \\
\hline $4^{\circ} \mathrm{C} ; 5 \mathrm{~d}$ & Solanum lycopersicum & A. thaliana & AtDREB1A & $\begin{array}{c}\text { Enzyme activities are enhanced in } \\
\text { transgenic plants as of SOD by } 29.49 \% \\
\text { and CAT by } 21.34 \% \text {. }\end{array}$ & [268] \\
\hline
\end{tabular}


Table 5. Cont.

\begin{tabular}{|c|c|c|c|c|c|}
\hline $\begin{array}{c}\text { Stress Condition and } \\
\text { Duration }\end{array}$ & Studied Plant & Source Plant & Gene & $\begin{array}{c}\text { Impact on Antioxidant Defense } \\
\text { Systems }\end{array}$ & References \\
\hline $4{ }^{\circ} \mathrm{C} ; 6,12,24,36$, and $48 \mathrm{~h}$ & S. tuberosum & S. tuberosum & StSOD1 & $\begin{array}{l}\text { Enzyme activities are enhanced in } \\
\text { transgenic plants as of SOD by } 1.38, \text { POD } \\
\text { by } 1.24 \text {, and CAT by } 1.37 \text { folds. }\end{array}$ & [269] \\
\hline \multicolumn{6}{|c|}{ Waterlogging } \\
\hline $\begin{array}{c}2 \mathrm{~cm} \text { waterlogging; } 3,6, \\
12,24, \text { and } 72 \mathrm{~h}\end{array}$ & A. thatiana & Brassica napus & $B n E R F 2.4$ & $\begin{array}{l}\text { Enzyme activities are enhanced in } \\
\text { transgenic plants, i.e., SOD, POD, } \\
\text { and CAT. }\end{array}$ & [280] \\
\hline $\begin{array}{l}\text { Soil-atmosphere interface } \\
\text { for } 1 \mathrm{w}\end{array}$ & A. thaliana & Mentha arvensis & MaRAP2-4 & $\begin{array}{c}\text { Enzyme activities are enhanced in } \\
\text { transgenic plants, i.e., CAT, GPX, } \\
\text { and SOD. }\end{array}$ & [281] \\
\hline $\begin{array}{l}5 \mathrm{~cm} \text { waterlogging; } 24 \text { and } \\
\qquad 48 \mathrm{~h}\end{array}$ & A. thaliana & Dioscorea alata & $D a A P X$ & $\begin{array}{l}\text { Enzyme activity is enhanced in } \\
\text { transgenic plants, i.e., APX but no } \\
\text { significant effect on CAT. }\end{array}$ & [217] \\
\hline $3 \mathrm{~cm}$ standing water; $14 \mathrm{~d}$ & $\begin{array}{l}\text { Chrysanthemum } \\
\text { morifolium }\end{array}$ & $\begin{array}{l}\text { Chrysanthemum } \\
\text { morifolium }\end{array}$ & CmSOS1 & $\begin{array}{l}\text { Overexpressed plants enhance the } \\
\text { activities of SOD and CAT by } 171 \% \text {. }\end{array}$ & [270] \\
\hline $\begin{array}{l}3.0 \mathrm{~cm} \text { above the } \\
\text { nutritional substance } \\
\text { surface; } 2 \text { weeks }\end{array}$ & A. thaliana & Hordeum vulgare & HvERF2.11 & $\begin{array}{l}\text { Enzyme activities are enhanced in } \\
\text { transgenic plants as of SOD by } 55 \%, 48 \% \text {, } \\
\text { and } 45 \%, \text { POD by } 64 \%, 65 \% \text {, and } 70 \% \text {, } \\
\text { CAT by } 2.2 \%, 2.1 \% \text {, and } 2.1 \% \text {, alcohol } \\
\text { dehydrogenases by } 2.1-, 2.3-\text {, and } 1.9-\text { fold } \\
\text { in three transgenic lines, respectively. }\end{array}$ & [282] \\
\hline
\end{tabular}


Interestingly, overexpression of $D a A P X$ combined with supplementation of transgenic plants with $\mathrm{H}_{2} \mathrm{O}_{2}$ significantly enhanced the activity of APX, improving flooding and cold tolerance [217]. Therefore, a number of genes have been documented to provide significant protection against abiotic stress through genetic modification in several plant species; however, many of the genes are yet to be reported in major crops.

\section{Conclusions and Perspectives}

It is understood that abiotic stresses are major limiting factors affecting plant growth and development, globally. Thus, there is a growing interest in deciphering the physiological, biochemical, molecular, and cellular mechanisms of abiotic stress responses and tolerance and to introduce potential mitigation techniques that would enhance sustainable agricultural production. Abiotic stresses lead to the accumulation of ROS, which can be a source of oxidative injury in plants. Initially, ROS were considered as toxic molecules and products of aerobic metabolism, found in several subcellular compartments. The metabolism of ROS is crucial in crop growth, development, adaptation, and existence under stressful environments. The production and scavenging of ROS are essential factors of plant defense processes, and modulation and overexpression of candidate genes encoding ROS detoxifying enzymes are widely used to enhance tolerance against several abiotic stresses. However, the balance among the detoxification and generation of ROS is maintained by both enzymatic and nonenzymatic antioxidant systems under stressful conditions. Notably, ROS are known to perform a dual role in plant biology due to molecular cross-talk with other signaling molecules such as RNS, RSS, and RCS. Based on the literature, ROS is very important for various biological mechanisms, such as cellular proliferation and differentiation, and are known to exert a signaling role at low concentrations. However, ROS toxicity openly kills cells through oxidative stress, which is the outcome of ROS-activated pathways responsible for cell death.

In addition, interrelationship exists between ROS, RNS, RSS, and RCS metabolisms under normal and stressed situations; however, a few studies have been carried out to address these interactions. Both ROS and RNS can create oxidative and nitrosative stress solely or together nitro-oxidative stress; however, they are also involved in signaling process of higher plants especially under adverse environmental situations. On the other hand, both ROS and RSS signals are identical and signal through their reaction with Cys, however, RSS signaling appears to be more extensive than ROS signaling. Contrary, RCS can regulate ROS metabolism since these molecules are direct products of oxidative stress and have the potential to act as its sensors. Therefore, these four reactive molecules could be the new gateway of interests for the plant biologists. Although accumulation of knowledge related to signaling roles of these reactive molecules have been accelerated over the last decade, more detailed work is needed to elucidate their roles in plant stress responses.

With the recent progress in molecular and genetic tools, significant progress has been made in enhancing stress tolerance in plants through the development of transgenic plants with increased activities of antioxidant enzymes. Nevertheless, overexpression of genes encoding antioxidant enzymes in transgenic plants has a positive effect on abiotic stress tolerance and the increasing potential of antioxidant enzymes. Based on the available literature, there is a need to identify and report candidate genes that can considerably enhance the tolerance and yield of transgenic plants under stressful environments. In addition, chemical priming offers an attractive alternative to genetic engineering in order to achieve similar goals, often through the regulation of the antioxidant defense apparatus. In the future, systems biology approaches such as genomics, transcriptomics, proteomics, and metabolomics could aid us in introducing new ways for the development of stress tolerance. The integration of these approaches should be implemented to identify key and stress-related regulators, genes, proteins, and metabolites. Furthermore, identification and manipulation of pathways associated with ROS-detoxifying regulators can be improved to generate stress tolerance genotypes.

In the field environment, the plant has to face a variety of stresses at once; thus, identification of core genes, which can confer multiple abiotic stress tolerance, is of paramount importance. In addition, 
state-of-the-art genome-editing tools like CRISPR/Cas could help to modify the genome through the development of mutant plants with single or multiple genes (ROS-detoxifying regulators) for proper plant growth and development and to enhance the activities of antioxidant defense systems. Recently, speed breeding has also emerged as a powerful tool to boost the growth and development of plants under desired conditions. Therefore, to save time, genome editing could be coupled with speed breeding to develop transgenic plants with induced antioxidant apparatus that are stress tolerant and will thus contribute to feed millions and to ensure world food security.

Author Contributions: Conceptualization, M.H., M.F., and V.F.; writing—original draft preparation, M.H., M.B.B., F.Z., A.R., S.M.M., and J.A.M.; and writing-review and editing, M.H., M.B.B., M.F., and V.F.; All authors have read and agreed to the published version of the manuscript.

Funding: This research received no external funding.

Acknowledgments: We acknowledge Khursheda Parvin, Tasnim Farha Bhuiyan, Taufika Islam Anee, Shahadat Hossen, and Kamrun Nahar for their help in collecting literature and some artworks. V.F. would like to acknowledge support by the Cyprus University of Technology Open Access Author Fund. M.H. acknowledges Sher-e-Bangla Agricultural University Research System (SAURES) for its funding in conducting recent research on plant stress physiology.

Conflicts of Interest: The authors declare no conflicts of interest.

\section{Abbreviations}

ABA-Abscisic acid; AEGs-Advanced glycation end products; AO-Aldehyde oxidase; RO•-Alkoxy radical; Al-Aluminum; As-Arsenic; APX-Ascorbate peroxidase; AsA-Ascorbic acid; AUX-Auxin; Cd-Cadmium; CAT-Catalase; Chl-Chlorophyll; Cr-Chromium; CA-Citric acid; Cu-Copper; Cys-Cysteine; DHA-Dehydroascorbate; DHAR-Dehydroascorbate reductase; DTP-Dual transgenic plants; EL-Electrolyte leakage; ETC-Electron transport chains; ET-Ethylene; RO*_Excited carbonyls; GRX-Glutaredoxin; GPX-Glutathione peroxidase; GR-Glutathione reductase; GST-Glutathione S-transferase; GOX-Glycolate oxidase; GOPX_Guaiacol peroxidase; HNE-4-Hydroxy-2(E)-nonenal; $\mathrm{HT}$-High temperature; $\mathrm{RH}-$ Hydrocarbon; $\mathrm{H}_{2} \mathrm{O}_{2}-$ Hydrogen peroxide; $\mathrm{H}_{2} \mathrm{~S}-\mathrm{Hydrogen}$ sulfide; $\mathrm{ROOH}-\mathrm{Hydroperoxides;} \mathrm{HO}_{2} \bullet-$ Hydroperoxyl radical; $\bullet \mathrm{OH}-\mathrm{Hydroxyl}$ radical; $\mathrm{HOBr}-\mathrm{Hypobromous} \mathrm{acid;}$ $\mathrm{HOCl}-\mathrm{Hypochlorous} \mathrm{acid;} \mathrm{HOI-Hypoiodous} \mathrm{acid;} \mathrm{JA-Jasmonic} \mathrm{acid;} \mathrm{Pb}-$ Lead; LOX-Lipoxygenases; LT-Low temperature; MDA-Malondialdehyde; MG-Methylglyoxal; MAPK-Mitogen-activated protein kinase; MDHA-Monodehydroascorbate; MDHAR-Monodehydroascorbate reductase; AOX-NADPH oxidase-like alternative oxidase; $\mathrm{Ni}-\mathrm{Nickel}$; NADPH-Nicotinamide adenine dinucleotide phosphate; NR-Nitrate reductase; NO-Nitric oxide; GSSG-Oxidized glutathione; OEC-Oxygen-evolving complex; $\mathrm{O}_{3}$-Ozone; POD/POX-Peroxidase; PRXs-Peroxiredoxins; $\mathrm{ROO}^{\bullet}$-Peroxyl radical; $\mathrm{ONOO}^{-}$-Peroxynitrite; $\mathrm{PhOH}$-Phenolic compounds; $\mathrm{PhO}^{\bullet}$-Phenoxyl radical; $\mathrm{pQ}$-Photochemical quenching; PS I-Photosystem I; PS II-Photosystem II; PSII-LHC-Photosystem II-light harvesting complex; PSII RC-Photosystem II-reaction center; PCs-Phytochelatins; PA-Polyamines; PEG-Polyethylene glycol; PPO-Polyphenol oxidase; PTM-Post-translational modification; PCD-Programmed cell death; $\mathrm{Q}_{\mathrm{A}}$-Quinone; RCS-Reactive carbonyl species; RNS_-Reactive nitrogen species; ROI-Reactive oxygen intermediates; ROS_Reactive oxygen species; RSS—Reactive sulfur species; GSH—Reduced glutathione; RWC—Relative water content; SA—Salicylic acid; $\mathrm{SQ}{ }^{\bullet-}$-Semiquinone; Si-Silicon; ${ }^{1} \mathrm{O}_{2}-$ Singlet oxygen; GSNO-S-nitrosoglutathione; $\mathrm{NaCl}-$ Sodium chloride; NaHS—Sodium hydrosulfide; $-\mathrm{SOH}-$ Sulfenic acid; $\mathrm{O}_{2}{ }^{\bullet-}$-Superoxide; SOD-Superoxide dismutase; TBARS-Thiobarbituric acid reactive substances; $-\mathrm{SH}$-Thiolate; TRXs-Thioredoxins; ${ }^{3} \mathrm{O}_{2}$-Triplet oxygen; UO-Urate oxidase; WL-Waterlogging; WT-Wild-type; XOD—Xanthine oxidase.

\section{References}

1. Pereira, A. Plant abiotic stress challenges from the changing environment. Front. Plant Sci. 2016, 7, 1123. [CrossRef] [PubMed]

2. Raza, A.; Razzaq, A.; Mehmood, S.S.; Zou, X.; Zhang, X.; Lv, Y.; Xu, J. Impact of climate change on crops adaptation and strategies to tackle its outcome: A review. Plants 2019, 8, 34. [CrossRef] [PubMed]

3. Mehla, N.; Sindhi, V.; Josula, D.; Bisht, P.; Wani, S.H. An introduction to antioxidants and their roles in plant stress tolerance. In Reactive Oxygen Species and Antioxidant Systems in Plants: Role and Regulation under Abiotic Stress; Khan, M.I.R., Khan, N.A., Eds.; Springer: Singapore, 2017; pp. 1-23.

4. Hasanuzzaman, M.; Bhuyan, M.; Anee, T.I.; Parvin, K.; Nahar, K.; Mahmud, J.A.; Fujita, M. Regulation of ascorbate-glutathione pathway in mitigating oxidative damage in plants under abiotic stress. Antioxidants 2019, 8, 384. [CrossRef] 
5. Choudhury, F.K.; Rivero, R.M.; Blumwald, E.; Mittler, R. Reactive oxygen species, abiotic stress and stress combination. Plant J. 2017, 90, 856-867. [CrossRef] [PubMed]

6. Singh, A.; Kumar, A.; Yadav, S.; Singh, I.K. Reactive oxygen species-mediated signaling during abiotic stress. Plant Gene 2019, 18, 100173. [CrossRef]

7. Raja, V.; Majeed, U.; Kang, H.; Andrabi, K.I.; John, R. Abiotic stress: Interplay between ROS, hormones and MAPKs. Environ. Exp. Bot. 2017, 137, 142-157. [CrossRef]

8. Gill, S.S.; Tuteja, N. Reactive oxygen species and antioxidant machinery in abiotic stress tolerance in crop plants. Plant Physiol. Biochem. 2010, 48, 909-930. [CrossRef]

9. Hasanuzzaman, M.; Hossain, M.A.; Teixeira da Silva, J.A.; Fujita, M. Plant responses and tolerance to abiotic oxidative stress: Antioxidant defense is a key factor. In Crop Stress and its Management: Perspectives and Strategies; Bandi, V., Shanker, A.K., Shanker, C., Mandapaka, M., Eds.; Springer: Berlin, Germany, 2012; pp. 261-316.

10. Kaur, N.; Kaur, J.; Grewal, S.K.; Singh, I. Effect of Heat Stress on Antioxidative defense system and its amelioration by heat acclimation and salicylic acid pre-treatments in three pigeonpea genotypes. Indian J. Agric. Biochem. 2019, 32, 106-110. [CrossRef]

11. Mittler, R. ROS are good. Trends Plant Sci. 2017, 22, 11-19. [CrossRef]

12. Antoniou, C.; Savvides, A.; Christou, A.; Fotopoulos, V. Unravelling chemical priming machinery in plants: The role of reactive oxygen-nitrogen-sulfur species in abiotic stress tolerance enhancement. Curr. Opin. Plant Biol. 2016, 33, 101-107. [CrossRef] [PubMed]

13. Sohag, A.A.M.; Tahjib-Ul-Arif, M.; Brestic, M.; Afrin, S.; Sakil, M.A.; Hossain, M.T.; Hossain, M.A.; Hossain, M.A. Exogenous salicylic acid and hydrogen peroxide attenuate drought stress in rice. Plant Soil Environ. 2020, 66, 7-13. [CrossRef]

14. Habib, N.; Ali, Q.; Ali, S.; Javed, M.T.; Zulqurnain Haider, M.; Perveen, R.; Shahid, M.R.; Rizwan, M.; Abdel-Daim, M.M.; Elkelish, A. Use of Nitric oxide and hydrogen peroxide for better yield of wheat (Triticum aestivum L.) under water deficit conditions: Growth, osmoregulation, and antioxidative defense mechanism. Plants 2020, 9, 285. [CrossRef] [PubMed]

15. Terzi, R.; Kadioglu, A.; Kalaycioglu, E.; Saglam, A. Hydrogen peroxide pretreatment induces osmotic stress tolerance by influencing osmolyte and abscisic acid levels in maize leaves. J. Plant Interact. 2014, 9, 559-565. [CrossRef]

16. Fariduddin, Q.; Khan, T.A.; Yusuf, M. Hydrogen peroxide mediated tolerance to copper stress in the presence of 28-homobrassinolide in Vigna radiata. Acta Physiol. Plant. 2014, 36, 2767-2778. [CrossRef]

17. Guler, N.S.; Pehlivan, N. Exogenous low-dose hydrogen peroxide enhances drought tolerance of soybean (Glycine max L.) through inducing antioxidant system. Acta Biol. Hung. 2016, 67, 169-183. [CrossRef]

18. Sun, Y.; Wang, H.; Liu, S.; Peng, X. Exogenous application of hydrogen peroxide alleviates drought stress in cucumber seedlings. S. Afr. J. Bot. 2016, 106, 23-28. [CrossRef]

19. Tanou, G.; Filippou, P.; Belghazi, M.; Job, D.; Diamantidis, G.; Fotopoulos, V.; Molassiotis, A. Oxidative and nitrosative-based signaling and associated post-translational modifications orchestrate the acclimation of citrus plants to salinity stress. Plant J. 2012, 72, 585-599. [CrossRef]

20. Christou, A.; Filippou, P.; Manganaris, G.A.; Fotopoulos, V. Sodium hydrosulfide induces systemic thermotolerance to strawberry plants through transcriptional regulation of heat shock proteins and aquaporin. BMC Plant Biol. 2014, 14, 1-11. [CrossRef]

21. Gohari, G.; Alavi, Z.; Esfandiari, E.; Panahirad, S.; Hajihoseinlou, S.; Fotopoulos, V. Interaction between hydrogen peroxide and sodium nitroprusside following chemical priming of Ocimum basilicum L. against salt stress. Physiol. Plant. 2020, 168,361-373. [CrossRef]

22. Hasanuzzaman, M.; Nahar, K.; Gill, S.S.; Alharby, H.F.; Razafindrabe, B.H.; Fujita, M. Hydrogen peroxide pretreatment mitigates cadmium-induced oxidative stress in Brassica napus L.: An intrinsic study on antioxidant defense and glyoxalase systems. Front. Plant Sci. 2017, 8, 115. [CrossRef]

23. Yamasaki, H.; Ogura, M.P.; Kingjoe, K.A.; Cohen, M.F. D-Cysteine-induced rapid root abscission in the water fern Azolla pinnata: Implications for the linkage between d-amino acid and reactive sulfur species (RSS) in plant environmental responses. Antioxidants 2019, 8, 411. [CrossRef] [PubMed]

24. Mailloux, J.R. Application of mitochondria-targeted pharmaceuticals for the treatment of heart disease. Curr. Pharm. Des. 2016, 22, 4763-4779. [CrossRef] [PubMed] 
25. Dmitrieva, V.A.; Tyutereva, E.V.; Voitsekhovskaja, O.V. Singlet oxygen in plants: Generation, detection, and signaling roles. Int. J. Mol. Sci. 2020, 21, 3237. [CrossRef] [PubMed]

26. Fischer, B.B.; Hideg, E.; Krieger-Liszkay, A. Production, detection, and signaling of singlet oxygen in photosynthetic organisms. Antioxid. Redox Signal. 2013, 18, 2145-2162. [CrossRef]

27. Rejeb, K.B.; Benzarti, M.; Debez, A.; Bailly, C.; Savouré, A.; Abdelly, C. NADPH oxidase-dependent $\mathrm{H}_{2} \mathrm{O}_{2}$ production is required for salt-induced antioxidant defense in Arabidopsis thaliana. J. Plant Physiol. 2015, 174, 5-15. [CrossRef]

28. Berwal, M.K.; Ram, C. Superoxide dismutase: A stable biochemical marker for abiotic stress tolerance in higher plants. In Abiotic and Biotic Stress in Plants; De Oliveira, A., Ed.; IntechOpen: London, UK, 2018. [CrossRef]

29. Mhamdi, A.; Noctor, G.; Baker, A. Plant catalases: Peroxisomal redox guardians. Arch. Biochem. Biophys. 2012, 525, 181-194. [CrossRef] [PubMed]

30. Demidchik, V. Mechanisms of oxidative stress in plants: From classical chemistry to cell biology. Environ. Exp. Bot. 2015, 109, 212-228. [CrossRef]

31. Maurya, A.K. Oxidative stress in crop plants. In Agronomic Crops; Hasanuzzaman, M., Ed.; Springer: Singapore, 2020; pp. 349-380.

32. Kapoor, D.; Sharma, R.; Handa, N.; Kaur, H.; Rattan, A.; Yadav, P.; Gautam, V.; Kaur, R.; Bhardwaj, R. Redox homeostasis in plants under abiotic stress: Role of electron carriers, energy metabolism mediators and proteinaceous thiols. Front. Environ. Sci. 2015, 3, 13. [CrossRef]

33. Nathan, C.; Ding, A. SnapShot: Reactive oxygen intermediates (ROI). Cell 2010, 140, 951. [CrossRef]

34. Farnese, F.S.; Menezes-Silva, P.E.; Gusman, G.S.; Oliveira, J.A. When bad guys become good ones: The key role of reactive oxygen species and nitric oxide in the plant responses to abiotic stress. Front. Plant Sci. 2016, 7, 471. [CrossRef]

35. Waszczak, C.; Carmody, M.; Kangasjärvi, J. Reactive oxygen species in plant signaling. Ann. Rev. Plant Biol. 2018, 69, 209-236. [CrossRef] [PubMed]

36. Molassiotis, A.; Fotopoulos, V. Oxidative and nitrosative signaling in plants: Two branches in the same tree? Plant Signal. Behav. 2011, 6, 210-214. [CrossRef] [PubMed]

37. Suzuki, N.; Koussevitzky, S.; Mittler, R.; Miller, G. ROS and redox signalling in the response of plants to abiotic stress. Plant Cell Environ. 2012, 35, 259-270. [CrossRef] [PubMed]

38. Noctor, G.; Foyer, C.H. Intracellular redox compartmentation and ROS-related communication in regulation and signaling. Plant Physiol. 2016, 171, 1581-1592. [CrossRef]

39. Kohli, S.K.; Khanna, K.; Bhardwaj, R.; Abd_Allah, E.F.; Ahmad, P.; Corpas, F.J. Assessment of subcellular ROS and NO metabolism in higher plants: Multifunctional signaling molecules. Antioxidants 2019, 8, 641. [CrossRef]

40. Dietz, K.-J. Thiol-based peroxidases and ascorbate peroxidases: Why plants rely on multiple peroxidase systems in the photosynthesizing chloroplast? Mol. Cells 2016, 39, 20.

41. Kim, C.; Dogra, V. Singlet oxygen metabolism: From genesis to signaling. Front. Plant Sci. 2019, 10, 1640.

42. Müller, P.; Li, X.-P.; Niyogi, K.K. Non-photochemical quenching. A response to excess light energy. Plant Physiol. 2001, 125, 1558-1566. [CrossRef]

43. Li, Z.; Wakao, S.; Fischer, B.B.; Niyogi, K.K. Sensing and responding to excess light. Ann. Rev. Plant Biol. 2009, 60, 239-260. [CrossRef]

44. Krieger-Liszkay, A. Singlet oxygen production in photosynthesis. J. Exp. Bot. 2005, 56, 337-346. [CrossRef]

45. Krieger-Liszkay, A.; Fufezan, C.; Trebst, A. Singlet oxygen production in photosystem II and related protection mechanism. Photosyn. Res. 2008, 98, 551-564. [CrossRef] [PubMed]

46. Flors, C.; Fryer, M.J.; Waring, J.; Reeder, B.; Bechtold, U.; Mullineaux, P.M.; Nonell, S.; Wilson, M.T.; Baker, N.R. Imaging the production of singlet oxygen in vivo using a new fluorescent sensor, Singlet Oxygen Sensor Green. J. Exp. Bot. 2006, 57, 1725-1734. [CrossRef] [PubMed]

47. Triantaphylidès, C.; Havaux, M. Singlet oxygen in plants: Production, detoxification and signaling. Trends Plant Sci. 2009, 14, 219-228. [CrossRef]

48. Bose, J.; Rodrigo-Moreno, A.; Shabala, S. ROS homeostasis in halophytes in the context of salinity stress tolerance. J. Exp. Bot. 2014, 65, 1241-1257. [CrossRef] [PubMed] 
49. Kerchev, P.; Waszczak, C.; Lewandowska, A.; Willems, P.; Shapiguzov, A.; Li, Z.; Alseekh, S.; Mühlenbock, P.; Hoeberichts, F.A.; Huang, J. Lack of glycolate oxidase1, but not glycolate oxidase2, attenuates the photorespiratory phenotype of catalase2-deficient arabidopsis. Plant Physiol. 2016, 171, 1704-1719. [CrossRef] [PubMed]

50. Del Río, L.A.; López-Huertas, E. ROS generation in peroxisomes and its role in cell signaling. Plant Cell Physiol. 2016, 57, 1364-1376. [CrossRef]

51. Reumann, S.; Chowdhary, G.; Lingner, T. Characterization, prediction and evolution of plant peroxisomal targeting signals type 1 (PTS1s). Biochim. Biophys. Acta 2016, 1863, 790-803. [CrossRef]

52. Corpas, F.J.; Del Río, L.A.; Palma, J.M. Plant peroxisomes at the crossroad of $\mathrm{NO}$ and $\mathrm{H}_{2} \mathrm{O}_{2}$ metabolism. J. Integr. Plant Biol. 2019, 61, 803-816.

53. Gilroy, S.; Białasek, M.; Suzuki, N.; Górecka, M.; Devireddy, A.R.; Karpiński, S.; Mittler, R. ROS, calcium, and electric signals: Key mediators of rapid systemic signaling in plants. Plant Physiol. 2016, 171, 1606-1615. [CrossRef]

54. Corpas, F.J.; González-Gordo, S.; Palma, J.M. Plant peroxisomes: A factory of reactive species. Front. Plant Sci. 2020, 11, 853. [CrossRef]

55. Lisenbee, C.S.; Lingard, M.J.; Trelease, R.N. Arabidopsis peroxisomes possess functionally redundant membrane and matrix isoforms of monodehydroascorbate reductase. Plant J. 2005, 43, 900-914. [CrossRef] [PubMed]

56. Leterrier, M.; Corpas, F.J.; Barroso, J.B.; Sandalio, L.M.; Luis, A. Peroxisomal monodehydroascorbate reductase. Genomic clone characterization and functional analysis under environmental stress conditions. Plant Physiol. 2005, 138, 2111-2123. [CrossRef] [PubMed]

57. Choudhary, A.; Kumar, A.; Kaur, N. ROS and oxidative burst: Roots in plant development. Plant Divers. 2020, 42, 33-43. [CrossRef] [PubMed]

58. Sharma, P.; Jha, A.B.; Dubey, R.S.; Pessarakli, M. Reactive oxygen species, oxidative damage, and antioxidative defense mechanism in plants under stressful conditions. J. Bot. 2012, 2012. [CrossRef]

59. Heyno, E.; Mary, V.; Schopfer, P.; Krieger-Liszkay, A. Oxygen activation at the plasma membrane: Relation between superoxide and hydroxyl radical production by isolated membranes. Planta 2011, 234, 35-45. [CrossRef]

60. Jeevan Kumar, S.; Rajendra Prasad, S.; Banerjee, R.; Thammineni, C. Seed birth to death: Dual functions of reactive oxygen species in seed physiology. Ann. Bot. 2015, 116, 663-668. [CrossRef]

61. Janků, M.; Luhová, L.; Petřivalský, M. On the origin and fate of reactive oxygen species in plant cell compartments. Antioxidants 2019, 8, 105. [CrossRef]

62. Decros, G.; Baldet, P.; Beauvoit, B.; Stevens, R.; Flandin, A.; Colombié, S.; Gibon, Y.; Pétriacq, P. Get the balance right: ROS homeostasis and redox signalling in fruit. Front. Plant Sci. 2019, 10, 1091. [CrossRef]

63. Paciolla, C.; Paradiso, A.; de Pinto, M.C. Cellular redox homeostasis as central modulator in plant stress response. In Redox State as a Central Regulator of Plant-Cell Stress Responses; Gupta, D., Palma, J., Corpas, F., Eds.; Springer: Cham, Switzerland, 2016; pp. 1-23.

64. Reczek, C.R.; Chandel, N.S. ROS-dependent signal transduction. Curr. Opin. Cell Biol. 2015, 33, 8-13. [CrossRef]

65. Schieber, M.; Chandel, N.S. ROS function in redox signaling and oxidative stress. Curr. Biol. 2014, 24, R453-R462. [CrossRef]

66. Finkel, T. Signal transduction by reactive oxygen species. J. Cell Biol. 2011, 194, 7-15. [CrossRef] [PubMed]

67. Panieri, E.; Santoro, M.M. ROS signaling and redox biology in endothelial cells. Cell. Mol. Life Sci. 2015, 72, 3281-3303. [CrossRef] [PubMed]

68. Mahmud, J.A.; Bhuyan, M.H.M.B.; Anee, T.I.; Nahar, K.; Fujita, M.; Hasanuzzaman, M. Reactive oxygen species metabolism and antioxidant defense in plants under metal/metalloid stress. In Plant Abiotic Stress Tolerance; Hasanuzzaman, M., Hakeem, K., Nahar, K., Alharby, H., Eds.; Springer: Cham, Switzerland, 2019; pp. 221-257.

69. Munns, R.; Tester, M. Mechanisms of salinity tolerance. Annu. Rev. Plant Biol. 2008, 59, 651-681. [CrossRef] [PubMed] 
70. Rehman, S.; Abbas, G.; Shahid, M.; Saqib, M.; Farooq, A.B.U.; Hussain, M.; Murtaza, B.; Amjad, M.; Naeem, M.A.; Farooq, A. Effect of salinity on cadmium tolerance, ionic homeostasis and oxidative stress responses in conocarpus exposed to cadmium stress: Implications for phytoremediation. Ecotoxicol. Environ. Saf. 2019, 171, 146-153. [CrossRef]

71. Cheng, Y.-W.; Kong, X.-W.; Wang, N.; Wang, T.-T.; Chen, J.; Shi, Z.Q. Thymol confers tolerance to salt stress by activating anti-oxidative defense and modulating $\mathrm{Na}^{+}$homeostasis in rice root. Ecotoxicol. Environ. Saf. 2020, 188, 109894. [CrossRef]

72. Ahanger, M.A.; Mir, R.A.; Alyemeni, M.N.; Ahmad, P. Combined effects of brassinosteroid and kinetin mitigates salinity stress in tomato through the modulation of antioxidant and osmolyte metabolism. Plant Physiol. Biochem. 2020, 147, 31-42. [CrossRef]

73. Abdelaal, K.A.; EL-Maghraby, L.M.; Elansary, H.; Hafez, Y.M.; Ibrahim, E.I.; El-Banna, M.; El-Esawi, M.; Elkelish, A. Treatment of sweet pepper with stress tolerance-inducing compounds alleviates salinity stress oxidative damage by mediating the physio-biochemical activities and antioxidant systems. Agronomy 2020, 10, 26. [CrossRef]

74. Ahmad, P.; Ahanger, M.A.; Alam, P.; Alyemeni, M.N.; Wijaya, L.; Ali, S.; Ashraf, M. Silicon (Si) supplementation alleviates $\mathrm{NaCl}$ toxicity in mung bean [Vigna radiata (L.) Wilczek] through the modifications of physio-biochemical attributes and key antioxidant enzymes. J. Plant Growth Regul. 2019, 38, 70-82. [CrossRef]

75. Arora, M.; Saxena, P.; Abdin, M.; Varma, A. Interaction between Piriformospora indica and Azotobacter chroococcum diminish the effect of salt stress in Artemisia annua L. by enhancing enzymatic and non-enzymatic antioxidants. Symbiosis 2020, 80, 61-73. [CrossRef]

76. Lalarukh, I.; Shahbaz, M. Response of antioxidants and lipid peroxidation to exogenous application of alpha-tocopherol in sunflower (Helianthus annuus L.) under salt stress. Pak. J. Bot. 2020, 52, 75-83. [CrossRef]

77. Tariq, A.; Shahbaz, M. Glycinebetaine induced modulation in oxidative defense system and mineral nutrients sesame (Sesamum indicum L.) under saline regimes. Pak. J. Bot. 2020, 52, 775-782. [CrossRef]

78. Mhadhbi, H.; Fotopoulos, V.; Mylona, P.V.; Jebara, M.; Aouani, M.E.; Polidoros, A.N. Alternative oxidase 1 (AOX1) gene expression in roots of Medicago truncatulais a genotype-specific component of salt stress tolerance. J. Plant Physiol. 2013, 170, 111-114. [CrossRef] [PubMed]

79. Filippou, P.; Bouchagier, P.; Skotti, E.; Fotopoulos, V. Proline and reactive oxygen/nitrogen species metabolism is involved in the tolerant response of the invasive plant species Ailanthus altissima to drought and salinity. Environ. Exp. Bot. 2014, 97, 1-10. [CrossRef]

80. Hasanuzzaman, M.; Nahar, K.; Khan, M.I.R.; Al Mahmud, J.; Alam, M.M.; Fujita, M. Regulation of reactive oxygen species metabolism and glyoxalase systems by exogenous osmolytes confers thermotolerance in Brassica napus. Gesunde Pflanz. 2020, 72, 3-16. [CrossRef]

81. Hasanuzzaman, M.; Nahar, K.; Gill, S.S.; Fujita, M. Drought stress responses in plants, oxidative stress, and antioxidant defense. In Climate Change and Plant Abiotic Stress Tolerance; Tuteja, N., Gill, S.S., Eds.; Wiley: Weinheim, Germany, 2014; pp. 209-250.

82. Fahad, S.; Bajwa, A.A.; Nazir, U.; Anjum, S.A.; Farooq, A.; Zohaib, A.; Sadia, S.; Nasim, W.; Adkins, S.; Saud, S. Crop production under drought and heat stress: Plant responses and management options. Front. Plant Sci. 2017, 8, 1147. [CrossRef]

83. Hasanuzzaman, M.; Nahar, K.; Rahman, A.; Inafuku, M.; Oku, H.; Fujita, M. Exogenous nitric oxide donor and arginine provide protection against short-term drought stress in wheat seedlings. Physiol. Mol. Biol. Plants 2018, 24, 993-1004. [CrossRef]

84. Abideen, Z.; Koyro, H.W.; Huchzermeyer, B.; Ansari, R.; Zulfiqar, F.; Gul, B. Ameliorating effects of biochar on photosynthetic efficiency and antioxidant defence of Phragmites karka under drought stress. Plant Biol. 2020, 22, 259-266. [CrossRef]

85. Campos, C.N.; Ávila, R.G.; de Souza, K.R.D.; Azevedo, L.M.; Alves, J.D. Melatonin reduces oxidative stress and promotes drought tolerance in young Coffea arabica L. plants. Agric. Water Manag. 2019, 211, 37-47. [CrossRef]

86. Saha, I.; De, A.K.; Sarkar, B.; Ghosh, A.; Dey, N.; Adak, M.K. Cellular response of oxidative stress when sub1A QTL of rice receives water deficit stress. Plant Sci. Today 2018, 5, 84-94. [CrossRef]

87. Satish, L.; Rency, A.S.; Ramesh, M. Spermidine sprays alleviate the water deficit-induced oxidative stress in finger millet (Eleusine coracana L. Gaertn.) plants. 3 Biotech 2018, 8, 63. [CrossRef] 
88. Malhotra, C.; Kapoor, R.T.; Ganjewala, D.; Singh, N. Sodium silicate mediated response of antioxidative defense system in Lycopersicon esculentum mill. under water stress. Int. J. Phytomed. 2017, 9, 364-378. [CrossRef]

89. Hasanuzzaman, M.; Nahar, K.; Hossain, M.S.; Anee, T.I.; Parvin, K.; Fujita, M. Nitric oxide pretreatment enhances antioxidant defense and glyoxalase systems to confer PEG-induced oxidative stress in rapeseed. J. Plant Interact. 2017, 12, 323-331. [CrossRef]

90. Hasanuzzaman, M.; Nahar, K.; Anee, T.; Khan, M.; Fujita, M. Silicon-mediated regulation of antioxidant defense and glyoxalase systems confers drought stress tolerance in Brassica napus L. S. Afr. J. Bot. 2018, 115, 50-57. [CrossRef]

91. Nahar, K.; Hasanuzzaman, M.; Alam, M.M.; Rahman, A.; Mahmud, J.A.; Suzuki, T.; Fujita, M. Insights into spermine-induced combined high temperature and drought tolerance in mung bean: Osmoregulation and roles of antioxidant and glyoxalase system. Protoplasma 2017, 254, 445-460. [CrossRef]

92. Abbas, T.; Rizwan, M.; Ali, S.; Adrees, M.; Mahmood, A.; Zia-ur-Rehman, M.; Ibrahim, M.; Arshad, M.; Qayyum, M.F. Biochar application increased the growth and yield and reduced cadmium in drought stressed wheat grown in an aged contaminated soil. Ecotoxicol. Environ. Saf. 2018, 148, 825-833. [CrossRef]

93. Liu, J.; Hasanuzzaman, M.; Wen, H.; Zhang, J.; Peng, T.; Sun, H.; Zhao, Q. High temperature and drought stress cause abscisic acid and reactive oxygen species accumulation and suppress seed germination growth in rice. Protoplasma 2019, 256, 1217-1227. [CrossRef]

94. Rezayian, M.; Ebrahimzadeh, H.; Niknam, V. Nitric oxide stimulates antioxidant system and osmotic adjustment in soybean under drought stress. J. Soil Sci. Plant Nutr. 2020, 1-11. [CrossRef]

95. Rady, M.M.; Belal, H.E.; Gadallah, F.M.; Semida, W.M. Selenium application in two methods promotes drought tolerance in Solanum lycopersicum plant by inducing the antioxidant defense system. Sci. Hortic. 2020, 266, 109290. [CrossRef]

96. Filippou, P.; Antoniou, C.; Fotopoulos, V. Effect of drought and rewatering on the cellular status and antioxidant response of Medicago truncatula plants. Plant Signal. Behav. 2011, 6, 270-277. [CrossRef]

97. Kusvuran, S.; Dasgan, H.Y. Effects of drought stress on physiological and biochemical changes in Phaseolus vulgaris L. Legume Res. 2017, 40, 55-62.

98. Hasanuzzaman, M.; Alam, M.M.; Nahar, K.; Mohsin, S.M.; Bhuyan, M.B.; Parvin, K.; Hawrylak-Nowak, B.; Fujita, M. Silicon-induced antioxidant defense and methylglyoxal detoxification works coordinately in alleviating nickel toxicity in Oryza sativa L. Ecotoxicology 2019, 28, 261-276. [CrossRef]

99. El-Amier, Y.; Elhindi, K.; El-Hendawy, S.; Al-Rashed, S.; Abd-ElGawad, A. Antioxidant system and biomolecules alteration in Pisum sativum under heavy metal stress and possible alleviation by 5-aminolevulinic acid. Molecules 2019, 24, 4194. [CrossRef]

100. Nahar, K.; Rahman, M.; Hasanuzzaman, M.; Alam, M.M.; Rahman, A.; Suzuki, T.; Fujita, M. Physiological and biochemical mechanisms of spermine-induced cadmium stress tolerance in mung bean (Vigna radiata $\mathrm{L}$.) seedlings. Environ. Sci. Pollut. Res. 2016, 23, 21206-21218. [CrossRef]

101. Hasanuzzaman, M.; Nahar, K.; Anee, T.I.; Fujita, M. Exogenous silicon attenuates cadmium-induced oxidative stress in Brassica napus L. by modulating AsA-GSH pathway and glyoxalase system. Front. Plant Sci. 2017, 8, 1061. [CrossRef]

102. Al Mahmud, J.; Hasanuzzaman, M.; Nahar, K.; Bhuyan, M.B.; Fujita, M. Insights into citric acid-induced cadmium tolerance and phytoremediation in Brassica juncea L.: Coordinated functions of metal chelation, antioxidant defense and glyoxalase systems. Ecotoxicol. Environ. Saf. 2018, 147, 990-1001. [CrossRef]

103. Gupta, D.; Pena, L.B.; Romero-Puertas, M.C.; Hernández, A.; Inouhe, M.; Sandalio, L.M. NADPH oxidases differentially regulate ROS metabolism and nutrient uptake under cadmium toxicity. Plant Cell Environ. 2017, 40, 509-526. [CrossRef]

104. Kabała, K.; Zboińska, M.; Głowiak, D.; Reda, M.; Jakubowska, D.; Janicka, M. Interaction between the signaling molecules hydrogen sulfide and hydrogen peroxide and their role in vacuolar $\mathrm{H}+$-ATPase regulation in cadmium-stressed cucumber roots. Physiol. Plant. 2019, 166, 688-704. [CrossRef]

105. Ahanger, M.A.; Aziz, U.; Sahli, A.A.; Alyemeni, M.N.; Ahmad, P. Combined kinetin and spermidine treatments ameliorate growth and photosynthetic inhibition in Vigna angularis by up-regulating antioxidant and nitrogen metabolism under cadmium stress. Biomolecules 2020, 10, 147. [CrossRef] 
106. Zaid, A.; Mohammad, F.; Fariduddin, Q. Plant growth regulators improve growth, photosynthesis, mineral nutrient and antioxidant system under cadmium stress in menthol mint (Mentha arvensis L.). Physiol. Mol. Biol. Plants 2020, 26, 25-39. [CrossRef]

107. Hasanuzzaman, M.; Nahar, K.; Rahman, A.; Mahmud, J.A.; Alharby, H.F.; Fujita, M. Exogenous glutathione attenuates lead-induced oxidative stress in wheat by improving antioxidant defense and physiological mechanisms. J. Plant Interact. 2018, 13, 203-212. [CrossRef]

108. Yadu, B.; Chandrakar, V.; Tamboli, R.; Keshavkant, S. Dimethylthiourea antagonizes oxidative responses by up-regulating expressions of pyrroline-5-carboxylate synthetase and antioxidant genes under arsenic stress. Int. J. Environ. Sci. Technol. 2019, 16, 8401-8410. [CrossRef]

109. Parvez, S.; Abbas, G.; Shahid, M.; Amjad, M.; Hussain, M.; Asad, S.A.; Imran, M.; Naeem, M.A. Effect of salinity on physiological, biochemical and photostabilizing attributes of two genotypes of quinoa (Chenopodium quinoa Willd.) exposed to arsenic stress. Ecotoxicol. Environ. Saf. 2020, 187, 109814. [CrossRef] [PubMed]

110. Georgiadou, E.C.; Kowalska, E.; Patla, K.; Kulbat, K.; Smolińska, B.; Leszczyńska, J.; Fotopoulos, V. Influence of heavy metals $(\mathrm{Ni}, \mathrm{Cu}$, and $\mathrm{Zn}$ ) on nitro-oxidative stress responses, proteome regulation and allergen production in basil (Ocimum basilicum L.) plants. Front. Plant Sci. 2018, 9, 862. [CrossRef]

111. Hasanuzzaman, M.; Nahar, K.; Alam, M.; Roychowdhury, R.; Fujita, M. Physiological, biochemical, and molecular mechanisms of heat stress tolerance in plants. Int. J. Mol. Sci. 2013, 14, 9643-9684. [CrossRef]

112. Fahad, S.; Hussain, S.; Saud, S.; Khan, F.; Hassan, S.; Nasim, W.; Arif, M.; Wang, F.; Huang, J. Exogenously applied plant growth regulators affect heat-stressed rice pollens. J. Agron. Crop Sci. 2016, 202, 139-150. [CrossRef]

113. Ding, X.; Jiang, Y.; He, L.; Zhou, Q.; Yu, J.; Hui, D.; Huang, D. Exogenous glutathione improves high root-zone temperature tolerance by modulating photosynthesis, antioxidant and osmolytes systems in cucumber seedlings. Sci. Rep. 2016, 6, 35424. [CrossRef]

114. Djanaguiraman, M.; Perumal, R.; Jagadish, S.; Ciampitti, I.; Welti, R.; Prasad, P. Sensitivity of sorghum pollen and pistil to high-temperature stress. Plant Cell Environ. 2018, 41, 1065-1082. [CrossRef]

115. Repetto, M.; Semprine, J.; Boveris, A. Lipid peroxidation: Chemical mechanism, biological implications and analytical determination. In Lipid Peroxidation; Catala, A., Ed.; InTech: Rijeka, Croatia, 2012; pp. 3-30.

116. Han, Q.-H.; Huang, B.; Ding, C.-B.; Zhang, Z.-W.; Chen, Y.-E.; Hu, C.; Zhou, L.-J.; Huang, Y.; Liao, J.-Q.; Yuan, S. Effects of melatonin on anti-oxidative systems and photosystem II in cold-stressed rice seedlings. Front. Plant Sci. 2017, 8, 785. [CrossRef]

117. Liu, T.; Ye, X.; Li, M.; Li, J.; Qi, H.; Hu, X. $\mathrm{H}_{2} \mathrm{O}_{2}$ and $\mathrm{NO}$ are involved in trehalose-regulated oxidative stress tolerance in cold-stressed tomato plants. Environ. Exp. Bot. 2020, 171, 103961. [CrossRef]

118. Xue, M.; Guo, T.; Ren, M.; Wang, Z.; Tang, K.; Zhang, W.; Wang, M. Constitutive expression of chloroplast glycerol-3-phosphate acyltransferase from Ammopiptanthus mongolicus enhances unsaturation of chloroplast lipids and tolerance to chilling, freezing and oxidative stress in transgenic Arabidopsis. Plant Physiol. Biochem. 2019, 143, 375-387. [CrossRef]

119. Loreti, E.; van Veen, H.; Perata, P. Plant responses to flooding stress. Curr. Opin. Plant Biol. 2016, 33, 64-71. [CrossRef] [PubMed]

120. Zhang, R.; Zhou, Y.; Yue, Z.; Chen, X.; Cao, X.; Xu, X.; Xing, Y.; Jiang, B.; Ai, X.; Huang, R. Changes in photosynthesis, chloroplast ultrastructure, and antioxidant metabolism in leaves of sorghum under waterlogging stress. Photosynthetica 2019, 57, 1076-1083. [CrossRef]

121. Anee, T.I.; Nahar, K.; Rahman, A.; Mahmud, J.A.; Bhuiyan, T.F.; Alam, M.U.; Fujita, M.; Hasanuzzaman, M. Oxidative damage and antioxidant defense in Sesamum indicum after different waterlogging durations. Plants 2019, 8, 196. [CrossRef]

122. Rasheed, R.; Iqbal, M.; Ashraf, M.A.; Hussain, I.; Shafiq, F.; Yousaf, A.; Zaheer, A. Glycine betaine counteracts the inhibitory effects of waterlogging on growth, photosynthetic pigments, oxidative defence system, nutrient composition, and fruit quality in tomato. J. Hortic. Sci. Biotechnol. 2018, 93, 385-391. [CrossRef]

123. Park, J.S.; Lee, E.J. Waterlogging induced oxidative stress and the mortality of the Antarctic plant, Deschampsia antarctica. J. Ecol. Environ. 2019, 43, 29. [CrossRef]

124. Alzahrani, S.M.; Alaraidh, I.A.; Migdadi, H.; Alghamdi, S.; Khan, M.A.; Ahmad, P. Physiological, biochemical, and antioxidant properties of two genotypes of Vicia faba grown under salinity stress. Pak. J. Bot. 2019, 51, 786-798. [CrossRef] 
125. Hossain, M.; Alam, M.; Rahman, A.; Hasanuzzaman, M.; Nahar, K.; Al Mahmud, J.; Fujita, M. Use of iso-osmotic solution to understand salt stress responses in lentil (Lens culinaris Medik.). S. Afr. J. Bot. 2017, 113, 346-354. [CrossRef]

126. Nxele, X.; Klein, A.; Ndimba, B. Drought and salinity stress alters ROS accumulation, water retention, and osmolyte content in sorghum plants. S. Afr. J. Bot. 2017, 108, 261-266. [CrossRef]

127. Derbali, W.; Goussi, R.; Koyro, H.-W.; Abdelly, C.; Manaa, A. Physiological and biochemical markers for screening salt tolerant quinoa genotypes at early seedling stage. J. Plant Interact. 2020, 15, 27-38. [CrossRef]

128. Han, F.; Sun, M.; He, W.; Cui, X.; Pan, H.; Wang, H.; Song, F.; Lou, Y.; Zhuge, Y. Ameliorating effects of exogenous $\mathrm{Ca}^{2+}$ on foxtail millet seedlings under salt stress. Funct. Plant Biol. 2019, 46, 407-416. [CrossRef]

129. Anjum, S.A.; Ashraf, U.; Tanveer, M.; Khan, I.; Hussain, S.; Shahzad, B.; Zohaib, A.; Abbas, F.; Saleem, M.F.; Ali, I. Drought induced changes in growth, osmolyte accumulation and antioxidant metabolism of three maize hybrids. Front. Plant Sci. 2017, 8. [CrossRef] [PubMed]

130. Antoniou, C.; Chatzimichail, G.; Xenofontos, R.; Pavlou, J.J.; Panagiotou, E.; Christou, A.; Fotopoulos, V. Melatonin systemically ameliorates drought stress-induced damage in Medicago sativa plants by modulating nitro-oxidative homeostasis and proline metabolism. J. Pineal Res. 2017, 62, e12401. [CrossRef] [PubMed]

131. Khan, A.; Anwar, Y.; Hasan, M.; Iqbal, A.; Ali, M.; Alharby, H.F.; Hakeem, K.R.; Hasanuzzaman, M. Attenuation of drought stress in Brassica seedlings with exogenous application of $\mathrm{Ca}^{2+}$ and $\mathrm{H}_{2} \mathrm{O}_{2}$. Plants 2017, 6, 20. [CrossRef] [PubMed]

132. Bhuiyan, T.F.; Ahamed, K.U.; Nahar, K.; Al Mahmud, J.; Bhuyan, M.B.; Anee, T.I.; Fujita, M.; Hasanuzzaman, M. Mitigation of PEG-induced drought stress in rapeseed (Brassica rapa L.) by exogenous application of osmolytes. Biocatal. Agric. Biotechnol. 2019, 20, 101197. [CrossRef]

133. Nahar, K.; Hasanuzzaman, M.; Suzuki, T.; Fujita, M. Polyamines-induced aluminum tolerance in mung bean: A study on antioxidant defense and methylglyoxal detoxification systems. Ecotoxicology 2017, 26, 58-73. [CrossRef] [PubMed]

134. Sarwar, M.; Saleem, M.F.; Ullah, N.; Rizwan, M.; Ali, S.; Shahid, M.R.; Alamri, S.A.; Alyemeni, M.N.; Ahmad, P. Exogenously applied growth regulators protect the cotton crop from heat-induced injury by modulating plant defense mechanism. Sci. Rep. 2018, 8, 1-15. [CrossRef]

135. Diao, Q.; Song, Y.; Shi, D.; Qi, H. Interaction of polyamines, abscisic acid, nitric oxide, and hydrogen peroxide under chilling stress in tomato (Lycopersicon esculentum Mill.) seedlings. Front. Plant Sci. 2017, 8, 203. [CrossRef]

136. Ghanbari, F.; Sayyari, M. Controlled drought stress affects the chilling-hardening capacity of tomato seedlings as indicated by changes in phenol metabolisms, antioxidant enzymes activity, osmolytes concentration and abscisic acid accumulation. Sci. Hortic. 2018, 229, 167-174. [CrossRef]

137. Luan, H.; Shen, H.; Pan, Y.; Guo, B.; Lv, C.; Xu, R. Elucidating the hypoxic stress response in barley (Hordeum vulgare L.) during waterlogging: A proteomics approach. Sci. Rep. 2018, 8, 1-13. [CrossRef]

138. Carocho, M.; Ferreira, I.C. A review on antioxidants, prooxidants and related controversy: Natural and synthetic compounds, screening and analysis methodologies and future perspectives. Food Chem. Toxicol. 2013, 51, 15-25. [CrossRef]

139. Nath, M.; Bhatt, D.; Bhatt, M.D.; Prasad, R.; Tuteja, N. Microbe-mediated enhancement of nitrogen and phosphorus content for crop improvement. In Crop Improvement through Microbial Biotechnology; Prasad, R., Gill, S.S., Tuteja, N., Eds.; Academic Press: Cambridge, UK, 2018; pp. 291-301.

140. Laxa, M.; Liebthal, M.; Telman, W.; Chibani, K.; Dietz, K.-J. The role of the plant antioxidant system in drought tolerance. Antioxidants 2019, 8, 94. [CrossRef]

141. Biczak, R. Quaternary ammonium salts with tetrafluoroborate anion: Phytotoxicity and oxidative stress in terrestrial plants. J. Hazard. Mater. 2016, 304, 173-185. [CrossRef] [PubMed]

142. Del Río, L.A.; Corpas, F.J.; López-Huertas, E.; Palma, J.M. Plant superoxide dismutases: Function under abiotic stress conditions. In Antioxidants and Antioxidant Enzymes in Higher Plants; Gupta, D., Palma, J., Corpas, F., Eds.; Springer: Cham, Switzerland, 2018; pp. 1-26.

143. Fotopoulos, V.; Tanou, G.; Ziogas, V.; Molassiotis, A. Involvement of AsA/DHA and GSH/GSSG ratios in gene and protein expression and in the activation of defense mechanisms under abiotic stress conditions. In Ascorbate-Glutathione Pathway and Stress Tolerance in Plants; Anjum, N.A., Chan, M.T., Umar, S., Eds.; Springer: Dordrecht, the Netherlands, 2010; pp. 265-302. 
144. Hasanuzzaman, M.; Bhuyan, M.; Mahmud, J.; Nahar, K.; Mohsin, S.; Parvin, K.; Fujita, M. Interaction of sulfur with phytohormones and signaling molecules in conferring abiotic stress tolerance to plants. Plant Signal. Behav. 2018, 13, e1477905. [CrossRef]

145. Foyer, C.H.; Noctor, G. Ascorbate and glutathione: The heart of the redox hub. Plant Physiol. 2011, 155, 2-18. [CrossRef] [PubMed]

146. Kapoor, D.; Singh, S.; Kumar, V.; Romero, R.; Prasad, R.; Singh, J. Antioxidant enzymes regulation in plants in reference to reactive oxygen species (ROS) and reactive nitrogen species (RNS). Plant Gene 2019, 19, 100182. [CrossRef]

147. Naz, H.; Akram, N.A.; Ashraf, M. Impact of ascorbic acid on growth and some physiological attributes of cucumber (Cucumis sativus) plants under water-deficit conditions. Pak. J. Bot. 2016, 48, 877-883.

148. Seminario, A.; Song, L.; Zulet, A.; Nguyen, H.T.; González, E.M.; Larrainzar, E. Drought stress causes a reduction in the biosynthesis of ascorbic acid in soybean plants. Front. Plant Sci. 2017, 8, 1042. [CrossRef]

149. Kumar, S.; Thakur, P.; Kaushal, N.; Malik, J.A.; Gaur, P.; Nayyar, H. Effect of varying high temperatures during reproductive growth on reproductive function, oxidative stress and seed yield in chickpea genotypes differing in heat sensitivity. Arch. Agron. Soil Sci. 2013, 59, 823-843. [CrossRef]

150. Hussain, H.A.; Men, S.; Hussain, S.; Chen, Y.; Ali, S.; Zhang, S.; Zhang, K.; Li, Y.; Xu, Q.; Liao, C. Interactive effects of drought and heat stresses on morpho-physiological attributes, yield, nutrient uptake and oxidative status in maize hybrids. Sci. Rep. 2019, 9, 1-12. [CrossRef]

151. Agati, G.; Azzarello, E.; Pollastri, S.; Tattini, M. Flavonoids as antioxidants in plants: Location and functional significance. Plant Sci. 2012, 196, 67-76. [CrossRef]

152. Liu, S.; Ju, J.; Xia, G. Identification of the flavonoid $3^{\prime}$-hydroxylase and flavonoid $3^{\prime}, 5^{\prime}$-hydroxylase genes from Antarctic moss and their regulation during abiotic stress. Gene 2014, 543, 145-152. [CrossRef] [PubMed]

153. Di Ferdinando, M.; Brunetti, C.; Fini, A.; Tattini, M. Flavonoids as antioxidants in plants under abiotic stresses. In Abiotic Stress Responses in Plants; Ahmad, P., Prasad, M., Eds.; Springer: New York, NY, USA, 2012; pp. 159-179.

154. Tiong, S.H.; Looi, C.Y.; Hazni, H.; Arya, A.; Paydar, M.; Wong, W.F.; Cheah, S.-C.; Mustafa, M.R.; Awang, K. Antidiabetic and antioxidant properties of alkaloids from Catharanthus roseus (L.) G. Don. Molecules 2013, 18, 9770-9784. [CrossRef] [PubMed]

155. Vranova, V.; Rejsek, K.; Skene, K.R.; Formanek, P. Non-protein amino acids: Plant, soil and ecosystem interactions. Plant Soil 2011, 342, 31-48. [CrossRef]

156. Gill, S.S.; Anjum, N.A.; Gill, R.; Yadav, S.; Hasanuzzaman, M.; Fujita, M.; Mishra, P.; Sabat, S.C.; Tuteja, N. Superoxide dismutase-mentor of abiotic stress tolerance in crop plants. Environ. Sci. Pollut. Res. 2015, 22, 10375-10394. [CrossRef]

157. Jovanović, S.V.; Kukavica, B.; Vidović, M.; Morina, F.; Menckhoff, L. Class III peroxidases: Functions, localization and redox regulation of isoenzymes. In Antioxidants and Antioxidant Enzymes in Higher Plants; Gupta, D., Palma, J., Corpas, F., Eds.; Springer: Cham, Switzerland, 2018; pp. 269-300.

158. Boeckx, T.; Winters, A.L.; Webb, K.J.; Kingston-Smith, A.H. Polyphenol oxidase in leaves: Is there any significance to the chloroplastic localization? J. Exp. Bot. 2015, 66, 3571-3579. [CrossRef]

159. Pandey, S.; Fartyal, D.; Agarwal, A.; Shukla, T.; James, D.; Kaul, T.; Negi, Y.K.; Arora, S.; Reddy, M.K. Abiotic stress tolerance in plants: Myriad roles of ascorbate peroxidase. Front. Plant Sci. 2017, 8, 581. [CrossRef]

160. García-Caparrós, P.; Hasanuzzaman, M.; Lao, M.T. Oxidative stress and antioxidant defense in plants under salinity. In Reactive Oxygen, Nitrogen and Sulfur Species in Plants: Production, Metabolism, Signaling and Defense Mechanisms; Hasanuzzaman, M., Fotopoulos, V., Nahar, K., Fujita, M., Eds.; John Wiley \& Sons: Hoboken, NJ, USA, 2019; pp. 291-309.

161. Couto, N.; Wood, J.; Barber, J. The role of glutathione reductase and related enzymes on cellular redox homoeostasis network. Free Radic. Biol. Med. 2016, 95, 27-42. [CrossRef]

162. Bela, K.; Horváth, E.; Gallé, Á.; Szabados, L.; Tari, I.; Csiszár, J. Plant glutathione peroxidases: Emerging role of the antioxidant enzymes in plant development and stress responses. J. Plant Physiol. 2015, 176, 192-201. [CrossRef]

163. Xu, J.; Xing, X.-J.; Tian, Y.-S.; Peng, R.-H.; Xue, Y.; Zhao, W.; Yao, Q.-H. Transgenic Arabidopsis plants expressing tomato glutathione $S$-transferase showed enhanced resistance to salt and drought stress. PLoS ONE 2015, 10, e0136960. [CrossRef] 
164. Christou, A.; Antoniou, C.; Christodoulou, C.; Hapeshi, E.; Stavrou, I.; Michael, C.; Fatta-Kassinos, D.; Fotopoulos, V. Stress-related phenomena and detoxification mechanisms induced by common pharmaceuticals in alfalfa (Medicago sativa L.) plants. Sci. Total Environ. 2016, 557, 652-664. [CrossRef]

165. Nianiou-Obeidat, I.; Madesis, P.; Kissoudis, C.; Voulgari, G.; Chronopoulou, E.; Tsaftaris, A.; Labrou, N.E. Plant glutathione transferase-mediated stress tolerance: Functions and biotechnological applications. Plant Cell Rep. 2017, 36, 791-805. [CrossRef] [PubMed]

166. Kumar, S.; Trivedi, P.K. Glutathione $S$-transferases: Role in combating abiotic stresses including arsenic detoxification in plants. Front. Plant Sci. 2018, 9, 751. [CrossRef]

167. Calderón, A.; Sevilla, F.; Jiménez, A. Redox protein thioredoxins: Function under salinity, drought and extreme temperature conditions. In Antioxidants and Antioxidant Enzymes in Higher Plants; Gupta, D., Palma, J., Corpas, F., Eds.; Springer: Cham, Switzerland, 2018; pp. 123-162.

168. Sevilla, F.; Jiménez, A.; Lázaro, J.J. What do the plant mitochondrial antioxidant and redox systems have to say under salinity, drought, and extreme temperature? In Reactive Oxygen Species and Oxidative Damage in Plants under Stress; Gupta, D.K., Palma, J.M., Corpas, F.J., Eds.; Springer: Cham, Switzerland, 2015; pp. $23-55$.

169. Pedrajas, J.R.; Bárcena, J.A. Peroxiredoxins: Types, characteristics and functions in higher plants. In Antioxidants and Antioxidant Enzymes in Higher Plants; Gupta, D., Palma, J., Corpas, F., Eds.; Springer: Cham, Switzerland, 2018; pp. 95-121.

170. Liebthal, M.; Maynard, D.; Dietz, K.-J. Peroxiredoxins and redox signaling in plants. Antioxid. Redox Signal. 2018, 28, 609-624. [CrossRef] [PubMed]

171. Hasanuzzaman, M.; Nahar, K.; Anee, T.I.; Fujita, M. Glutathione in plants: Biosynthesis and physiological role in environmental stress tolerance. Physiol. Mol. Biol. Plants 2017, 23, 249-268. [CrossRef] [PubMed]

172. Cunha, J.R.; Neto, M.C.L.; Carvalho, F.E.; Martins, M.O.; Jardim-Messeder, D.; Margis-Pinheiro, M.; Silveira, J.A. Salinity and osmotic stress trigger different antioxidant responses related to cytosolic ascorbate peroxidase knockdown in rice roots. Environ. Exp. Bot. 2016, 131, 58-67. [CrossRef]

173. Li, Y.; Cao, X.L.; Zhu, Y.; Yang, X.M.; Zhang, K.N.; Xiao, Z.Y.; Wang, H.; Zhao, J.H.; Zhang, L.L.; Li, G.B. Osa-miR398b boosts $\mathrm{H}_{2} \mathrm{O}_{2}$ production and rice blast disease-resistance via multiple superoxide dismutases. New Phytol. 2019, 222, 1507-1522. [CrossRef] [PubMed]

174. Vighi, I.; Benitez, L.; Amaral, M.; Moraes, G.; Auler, P.; Rodrigues, G.; Deuner, S.; Maia, L.; Braga, E. Functional characterization of the antioxidant enzymes in rice plants exposed to salinity stress. Biol. Plant. 2017, 61, 540-550. [CrossRef]

175. Zeeshan, M.; Lu, M.; Sehar, S.; Holford, P.; Wu, F. Comparison of biochemical, anatomical, morphological, and physiological responses to salinity stress in wheat and barley genotypes deferring in salinity tolerance. Agronomy 2020, 10, 127. [CrossRef]

176. Zulfiqar, F.; Akram, N.A.; Ashraf, M. Osmoprotection in plants under abiotic stresses: New insights into a classical phenomenon. Planta 2020, 251,3. [CrossRef]

177. Numan, M.; Bashir, S.; Khan, Y.; Mumtaz, R.; Shinwari, Z.K.; Khan, A.L.; Khan, A.; Ahmed, A.-H. Plant growth promoting bacteria as an alternative strategy for salt tolerance in plants: A review. Microbiol. Res. 2018, 209, 21-32. [CrossRef]

178. Zulfiqar, F.; Casadesús, A.; Brockman, H.; Munné-Bosch, S. An overview of plant-based natural biostimulants for sustainable horticulture with a particular focus on moringa leaf extracts. Plant Sci. 2019, 110194. [CrossRef] [PubMed]

179. Alsahli, A.; Mohamed, A.-K.; Alaraidh, I.; Al-Ghamdi, A.; Al-Watban, A.; El-Zaidy, M.; Alzahrani, S.M. Salicylic acid alleviates salinity stress through the modulation of biochemical attributes and some key antioxidants in wheat seedlings. Pak. J. Bot. 2019, 51, 1551-1559. [CrossRef]

180. Ali, A.Y.A.; Ibrahim, M.E.H.; Zhou, G.; Nimir, N.E.A.; Jiao, X.; Zhu, G.; Elsiddig, A.M.I.; Suliman, M.S.E.; Elradi, S.B.M.; Yue, W. Exogenous jasmonic acid and humic acid increased salinity tolerance of sorghum. Agron. J. 2020, 112, 871-884. [CrossRef]

181. Tanou, G.; Ziogas, V.; Belghazi, M.; Christou, A.; Filippou, P.; Job, D.; Fotopoulos, V.; Molassiotis, A. Polyamines reprogram oxidative and nitrosative status and the proteome of citrus plants exposed to salinity stress. Plant Cell Environ. 2014, 37, 864-885. [CrossRef] 
182. Ahanger, M.A.; Qin, C.; Begum, N.; Maodong, Q.; Dong, X.X.; El-Esawi, M.; El-Sheikh, M.A.; Alatar, A.A.; Zhang, L. Nitrogen availability prevents oxidative effects of salinity on wheat growth and photosynthesis by up-regulating the antioxidants and osmolytes metabolism, and secondary metabolite accumulation. BMC Plant Biol. 2019, 19, 1-12. [CrossRef]

183. Chung, Y.S.; Kim, K.-S.; Hamayun, M.; Kim, Y. Silicon confers soybean resistance to salinity stress through regulation of reactive oxygen and reactive nitrogen species. Front. Plant Sci. 2019, 10, 1725. [CrossRef]

184. Christou, A.; Manganaris, G.A.; Papadopoulos, I.; Fotopoulos, V. Hydrogen sulfide induces systemic tolerance to salinity and non-ionic osmotic stress in strawberry plants through modification of reactive species biosynthesis and transcriptional regulation of multiple defence pathways. J. Exp. Bot. 2013, 64, 1953-1966. [CrossRef]

185. Santander, C.; Ruiz, A.; García, S.; Aroca, R.; Cumming, J.; Cornejo, P. Efficiency of two arbuscular mycorrhizal fungal inocula to improve saline stress tolerance in lettuce plants by changes of antioxidant defense mechanisms. J. Sci. Food Agric. 2020, 100, 1577-1587. [CrossRef]

186. Rady, M.M.; Kuşvuran, A.; Alharby, H.F.; Alzahrani, Y.; Kuşvuran, S. Pretreatment with proline or an organic bio-stimulant induces salt tolerance in wheat plants by improving antioxidant redox state and enzymatic activities and reducing the oxidative stress. J. Plant Growth Regul. 2019, 38, 449-462. [CrossRef]

187. Rady, M.M.; Elrys, A.S.; El-Maati, M.F.A.; Desoky, E.-S.M. Interplaying roles of silicon and proline effectively improve salt and cadmium stress tolerance in Phaseolus vulgaris plant. Plant Physiol. Biochem. 2019, 139, 558-568. [CrossRef]

188. Heydari, H.; Rezayian, M.; Niknam, V.; Ebrahimzadeh, H. Role of Penconazole in salt stress amelioration in Sesamum indicum L. Soil Sci. Plant Nutr. 2019, 65, 243-250. [CrossRef]

189. Akram, N.A.; Iqbal, M.; Muhammad, A.; Ashraf, M.; Al-Qurainy, F.; Shafiq, S. Aminolevulinic acid and nitric oxide regulate oxidative defense and secondary metabolisms in canola (Brassica napus L.) under drought stress. Protoplasma 2018, 255, 163-174. [CrossRef] [PubMed]

190. Guo, Y.; Tian, S.; Liu, S.; Wang, W.; Sui, N. Energy dissipation and antioxidant enzyme system protect photosystem II of sweet sorghum under drought stress. Photosynthetica 2018, 56, 861-872. [CrossRef]

191. Hassan, N.; Ebeed, H.; Aljaarany, A. Exogenous application of spermine and putrescine mitigate adversities of drought stress in wheat by protecting membranes and chloroplast ultra-structure. Physiol. Mol. Biol. Plants 2020, 26, 233-245. [CrossRef]

192. Antoniou, C.; Xenofontos, R.; Chatzimichail, G.; Christou, A.; Kashfi, K.; Fotopoulos, V. Exploring the potential of nitric oxide and hydrogen sulfide (NOSH)-releasing synthetic compounds as novel priming agents against drought stress in Medicago sativa plants. Biomolecules 2020, 10, 120. [CrossRef]

193. Gratão, P.L.; Alves, L.R.; Lima, L.W. Heavy metal toxicity and plant productivity: Role of metal scavengers. In Plant-Metal Interactions; Srivastava, S., Srivastava, A.K., Suprasanna, P., Eds.; Springer: Cham, Switzerland, 2019; pp. 49-60.

194. Chakravarthi, S.; Jessop, C.E.; Bulleid, N.J. The role of glutathione in disulphide bond formation and endoplasmic-reticulum-generated oxidative stress. EMBO Rep. 2006, 7, 271-275. [CrossRef]

195. Petrussa, E.; Braidot, E.; Zancani, M.; Peresson, C.; Bertolini, A.; Patui, S.; Vianello, A. Plant flavonoids—biosynthesis, transport and involvement in stress responses. Int. J. Mol. Sci. 2013, 14, 14950-14973. [CrossRef]

196. Landi, M.; Tattini, M.; Gould, K.S. Multiple functional roles of anthocyanins in plant-environment interactions. Environ. Exp. Bot. 2015, 119, 4-17. [CrossRef]

197. Awasthi, R.; Gaur, P.; Turner, N.C.; Vadez, V.; Siddique, K.H.; Nayyar, H. Effects of individual and combined heat and drought stress during seed filling on the oxidative metabolism and yield of chickpea (Cicer arietinum) genotypes differing in heat and drought tolerance. Crop Past. Sci. 2017, 68, 823-841. [CrossRef]

198. Sarkar, J.; Chakraborty, B.; Chakraborty, U. Temperature stress induced antioxidative and biochemical changes in wheat (Triticum aestivum L.) cultivars. J. Plant Stress Physiol. 2016, 22-30. [CrossRef]

199. Zandalinas, S.I.; Balfagón, D.; Arbona, V.; Gómez-Cadenas, A. Modulation of antioxidant defense system is associated with combined drought and heat stress tolerance in citrus. Front. Plant Sci. 2017, 8, 953. [CrossRef] [PubMed]

200. Zhao, H.; Ye, L.; Wang, Y.; Zhou, X.; Yang, J.; Wang, J.; Cao, K.; Zou, Z. Melatonin increases the chilling tolerance of chloroplast in cucumber seedlings by regulating photosynthetic electron flux and the ascorbate-glutathione cycle. Front. Plant Sci. 2016, 7, 1814. [CrossRef] [PubMed] 
201. Shi, H.; Ye, T.; Zhong, B.; Liu, X.; Chan, Z. Comparative proteomic and metabolomic analyses reveal mechanisms of improved cold stress tolerance in bermudagrass (Cynodon dactylon (L.) Pers.) by exogenous calcium. J. Integr. Plant Biol. 2014, 56, 1064-1079. [CrossRef] [PubMed]

202. Wani, M.A.; Jan, N.; Qazi, H.A.; Andrabi, K.I.; John, R. Cold stress induces biochemical changes, fatty acid profile, antioxidant system and gene expression in Capsella bursa pastoris L. Acta Physiol. Plant. 2018, 40, 167. [CrossRef]

203. Mohammadrezakhani, S.; Hajilou, J.; Rezanejad, F.; Zaare-Nahandi, F. Assessment of exogenous application of proline on antioxidant compounds in three citrus species under low temperature stress. J. Plant Interact. 2019, 14, 347-358. [CrossRef]

204. Spanò, C.; Bottega, S.; Castiglione, M.R.; Pedranzani, H.E. Antioxidant response to cold stress in two oil plants of the genus Jatropha. Plant Soil Environ. 2017, 63, 271-276.

205. Cheng, F.; Lu, J.; Gao, M.; Shi, K.; Kong, Q.; Huang, Y.; Bie, Z. Redox signaling and CBF-responsive pathway are involved in salicylic acid-improved photosynthesis and growth under chilling stress in watermelon. Front. Plant Sci. 2016, 7, 1519. [CrossRef]

206. Wang, Q.J.; Sun, H.; Dong, Q.L.; Sun, T.Y.; Jin, Z.X.; Hao, Y.J.; Yao, Y.X. The enhancement of tolerance to salt and cold stresses by modifying the redox state and salicylic acid content via the cytosolic malate dehydrogenase gene in transgenic apple plants. Plant Biotechnol. J. 2016, 14, 1986-1997. [CrossRef]

207. Li, W.; Mo, W.; Ashraf, U.; Li, G.; Wen, T.; Abrar, M.; Gao, L.; Liu, J.; Hu, J. Evaluation of physiological indices of waterlogging tolerance of different maize varieties in South China. Appl. Ecol. Environ. Res. 2018, 16, 2059-2072. [CrossRef]

208. Qin, C.; Ahanger, M.A.; Zhou, J.; Ahmed, N.; Wei, C.; Yuan, S.; Ashraf, M.; Zhang, L. Beneficial role of acetylcholine in chlorophyll metabolism and photosynthetic gas exchange in Nicotiana benthamiana seedlings under salinity stress. Plant Biol. 2020, 22, 357-365. [CrossRef]

209. Parvin, K.; Nahar, K.; Hasanuzzaman, M.; Bhuyan, M.B.; Mohsin, S.M.; Fujita, M. Exogenous vanillic acid enhances salt tolerance of tomato: Insight into plant antioxidant defense and glyoxalase systems. Plant Physiol. Biochem. 2020, 150, 109-120. [CrossRef] [PubMed]

210. Cen, H.; Wang, T.; Liu, H.; Tian, D.; Zhang, Y. Melatonin application improves salt tolerance of alfalfa (Medicago sativa L.) by enhancing antioxidant capacity. Plants 2020, 9, 220. [CrossRef] [PubMed]

211. Zhang, T.; Shi, Z.; Zhang, X.; Zheng, S.; Wang, J.; Mo, J. Alleviating effects of exogenous melatonin on salt stress in cucumber. Sci. Hortic. 2020, 262, 109070. [CrossRef]

212. Sehar, Z.; Masood, A.; Khan, N.A. Nitric oxide reverses glucose-mediated photosynthetic repression in wheat (Triticum aestivum L.) under salt stress. Environ. Exp. Bot. 2019, 161, 277-289. [CrossRef]

213. Jiang, J.-L.; Tian, Y.; Li, L.; Yu, M.; Hou, R.-P.; Ren, X.-M. H2S alleviates salinity stress in cucumber by maintaining the $\mathrm{Na}^{+} / \mathrm{K}^{+}$balance and regulating $\mathrm{H}_{2} \mathrm{~S}$ metabolism and oxidative stress response. Front. Plant Sci. 2019, 10, 678. [CrossRef] [PubMed]

214. Jahan, B.; AlAjmi, M.F.; Rehman, M.T.; Khan, N. Treatment of nitric oxide supplemented with nitrogen and sulfur regulates photosynthetic performance and stomatal behavior in mustard under salt stress. Physiol. Plant. 2020, 168, 490-510.

215. Hamim, H.; Violita, V.; Triadiati, T.; Miftahudin, M. Oxidative stress and photosynthesis reduction of cultivated (Glycine max L.) and wild soybean (G. tomentella L.) exposed to drought and paraquat. Asian J. Plant Sci. 2017, 16, 65-77. [CrossRef]

216. Jan, N.; Majeed, U.; Andrabi, K.I.; John, R. Cold stress modulates osmolytes and antioxidant system in Calendula officinalis. Acta Physiol. Plant. 2018, 40, 73. [CrossRef]

217. Chen, Z.-Y.; Wang, Y.-T.; Pan, X.-B.; Xi, Z.-M. Amelioration of cold-induced oxidative stress by exogenous 24-epibrassinolide treatment in grapevine seedlings: Toward regulating the ascorbate-glutathione cycle. Sci. Hortic. 2019, 244, 379-387. [CrossRef]

218. Mittler, R.; Vanderauwera, S.; Gollery, M.; Van Breusegem, F. Reactive oxygen gene network of plants. Trends Plant. Sci. 2004, 9, 490-498. [CrossRef]

219. Neill, S.; Desikan, R.; Hancock, J. Hydrogen peroxide signalling. Curr. Opin. Plant Biol. 2002, 5, 388-395. [CrossRef]

220. Neill, S.J.; Desikan, R.; Clarke, A.; Hurst, R.D.; Hancock, J.T. Hydrogen peroxide and nitric oxide as signalling molecules in plants. J. Exp. Bot. 2002, 53, 1237-1247. [CrossRef] [PubMed] 
221. Asada, K. Production and scavenging of reactive oxygen species in chloroplasts and their functions. Plant Physiol. 2006, 141, 391-396. [CrossRef] [PubMed]

222. Kar, R.K. Plant responses to water stress: Role of reactive oxygen species. Plant Signal. Behav. 2011, 6, 1741-1745. [CrossRef] [PubMed]

223. Niu, L.; Liao, W. Hydrogen peroxide signaling in plant development and abiotic responses: Crosstalk with nitric oxide and calcium. Front. Plant Sci. 2016, 7, 230. [CrossRef]

224. Janicka, M.; Reda, M.; Napieraj, N.; Kabała, K. Plant abiotic stress: Function of nitric oxide and hydrogen peroxide. In Nitric Oxide and Hydrogen Peroxide Signaling in Higher Plants; Gupta, D., Palma, J., Corpas, F., Eds.; Springer: Cham, Swizerland, 2019; pp. 201-219.

225. Savvides, A.; Ali, S.; Tester, M.; Fotopoulos, V. Chemical priming of plants against multiple abiotic stresses: Mission possible? Trends Plant Sci. 2016, 21, 329-340. [CrossRef]

226. Kaur, P.; Handa, N.; Verma, V.; Bakshi, P.; Kalia, R.; Sareen, S.; Nagpal, A.; Vig, A.; Mir, B.A.; Bhardwaj, R. Cross talk among reactive oxygen, nitrogen and sulfur during abiotic stress in plants. In Reactive Oxygen, Nitrogen and Sulfur Species in Plants: Production, Metabolism, Signaling and Defense Mechanisms; Hasanuzzaman, M., Fotopoulos, V., Nahar, K., Fujita, M., Eds.; John Wiley \& Sons: Hoboken, NJ, USA, 2019; pp. 857-871.

227. Hancock, J.T.; Whiteman, M. Hydrogen sulfide signaling: Interactions with nitric oxide and reactive oxygen species. Ann. N. Y. Acad. Sci. 2016, 1365, 5-14. [CrossRef]

228. Biswas, M.S.; Fukaki, H.; Mori, I.C.; Nakahara, K.; Mano, J.I. Reactive oxygen species and reactive carbonyl species constitute a feed-forward loop in auxin signaling for lateral root formation. Plant J. 2019, 100, 536-548. [CrossRef]

229. Li, J.-T.; Qiu, Z.-B.; Zhang, X.-W.; Wang, L.-S. Exogenous hydrogen peroxide can enhance tolerance of wheat seedlings to salt stress. Acta Physiol. Plant. 2011, 33, 835-842. [CrossRef]

230. Liu, Z.-J.; Guo, Y.-K.; Bai, J.-G. Exogenous hydrogen peroxide changes antioxidant enzyme activity and protects ultrastructure in leaves of two cucumber ecotypes under osmotic stress. J. Plant Growth Regul. 2010, 29, 171-183. [CrossRef]

231. Zhang, X.-L.; Jia, X.-F.; Yu, B.; Gao, Y.; Bai, J.-G. Exogenous hydrogen peroxide influences antioxidant enzyme activity and lipid peroxidation in cucumber leaves at low light. Sci. Hortic. 2011, 129, 656-662. [CrossRef]

232. Nawaz, F.; Majeed, S.; Ahmad, K.S.; Aqib, M.; Shehzad, M.A.; Aurangzaib, M.; Shahbaz, M. Reactive sulfur species-key regulators of abiotic stress tolerance in plants. In Reactive Oxygen, Nitrogen and Sulfur Species in Plants: Production, Metabolism, Signaling and Defense Mechanisms; Hasanuzzaman, M., Fotopoulos, V., Nahar, K., Fujita, M., Eds.; John Wiley \& Sons: Hoboken, NJ, USA, 2019; pp. 685-713.

233. Hasanuzzaman, M.; Oku, H.; Nahar, K.; Bhuyan, M.B.; Al Mahmud, J.; Baluska, F.; Fujita, M. Nitric oxide-induced salt stress tolerance in plants: ROS metabolism, signaling, and molecular interactions. Plant Biotechnol. Rep. 2018, 12, 77-92. [CrossRef]

234. Bhuyan, M.B.; Hasanuzzaman, M.; Parvin, K.; Mohsin, S.M.; Al Mahmud, J.; Nahar, K.; Fujita, M. Nitric oxide and hydrogen sulfide: Two intimate collaborators regulating plant defense against abiotic stress. Plant Growth Regul. 2020, 1-16. [CrossRef]

235. Hasanuzzaman, M.; Nahar, K.; Alam, M.M.; Bhuyan, M.B.; Oku, H.; Fujita, M. Exogenous nitric oxide pretreatment protects Brassica napus L. seedlings from paraquat toxicity through the modulation of antioxidant defense and glyoxalase systems. Plant Physiol. Biochem. 2018, 126, 173-186. [CrossRef]

236. Bright, J.; Desikan, R.; Hancock, J.T.; Weir, I.S.; Neill, S.J. ABA-induced NO generation and stomatal closure in Arabidopsis are dependent on $\mathrm{H}_{2} \mathrm{O}_{2}$ synthesis. Plant J. 2006, 45, 113-122. [CrossRef]

237. González, A.; de Los Ángeles Cabrera, M.; Henríquez, M.J.; Contreras, R.A.; Morales, B.; Moenne, A. Cross talk among calcium, hydrogen peroxide, and nitric oxide and activation of gene expression involving calmodulins and calcium-dependent protein kinases in Ulva compressa exposed to copper excess. Plant Physiol. 2012, 158, 1451-1462. [CrossRef]

238. Zhang, A.; Jiang, M.; Zhang, J.; Ding, H.; Xu, S.; Hu, X.; Tan, M. Nitric oxide induced by hydrogen peroxide mediates abscisic acid-induced activation of the mitogen-activated protein kinase cascade involved in antioxidant defense in maize leaves. New Phytol. 2007, 175, 36-50. [CrossRef]

239. Qiao, W.; Li, C.; Fan, L.-M. Cross-talk between nitric oxide and hydrogen peroxide in plant responses to abiotic stresses. Environ. Exp. Bot. 2014, 100, 84-93. [CrossRef] 
240. Palma, J.M.; Gupta, D.K.; Corpas, F.J. Hydrogen peroxide and nitric oxide generation in plant cells: Overview and queries. In Nitric Oxide and Hydrogen Peroxide Signaling in Higher Plants; Springer: Cham, Swizerland, 2019; pp. 1-16.

241. Corpas, F.J.; Gupta, D.K.; Palma, J.M. Production sites of reactive oxygen species (ROS) in organelles from plant cells. In Reactive Oxygen Species and Oxidative Damage in Plants under Stress; Gupta, D.K., Palma, J.M., Corpas, F.J., Eds.; Springer: Cham, Swizerland, 2015; pp. 1-22.

242. Corpas, F.J.; Barroso, J.B.; Palma, J.M.; Rodriguez-Ruiz, M. Plant peroxisomes: A nitro-oxidative cocktail. Redox Biol. 2017, 11, 535-542. [CrossRef]

243. Radi, R. Nitric oxide, oxidants, and protein tyrosine nitration. In Proceedings of the National Academy of Sciences of the United States of America, Los Angeles, CA, USA, 12 January 2004; pp. 4003-4008.

244. Liu, D.; Liu, M.; Liu, X.-L.; Cheng, X.-G.; Liang, Z.-W. Silicon priming created an enhanced tolerance in alfalfa (Medicago sativa L.) seedlings in response to high alkaline stress. Front. Plant Sci. 2018, 9, 716. [CrossRef]

245. Ortega-Galisteo, A.P.; Rodríguez-Serrano, M.; Pazmiño, D.M.; Gupta, D.K.; Sandalio, L.M.; Romero-Puertas, M. S-Nitrosylated proteins in pea (Pisum sativum L.) leaf peroxisomes: Changes under abiotic stress. J. Exp. Bot. 2012, 63, 2089-2103. [CrossRef] [PubMed]

246. Gruhlke, M.C. Reactive sulfur species: A new player in plant physiology? In Reactive Oxygen, Nitrogen and Sulfur Species in Plants: Production, Metabolism, Signaling and Defense Mechanisms; Hasanuzzaman, M., Fotopoulos, V., Nahar, K., Fujita, M., Eds.; John Wiley \& Sons: Hoboken, NJ, USA, 2019; pp. 715-728.

247. Hill, B.G.; Bhatnagar, A. Protein S-glutathiolation: Redox-sensitive regulation of protein function. J. Mol. Cell. Cardiol. 2012, 52, 559-567. [CrossRef]

248. Tao, L.; English, A.M. Protein S-glutathiolation triggered by decomposed S-nitrosoglutathione. Biochemistry 2004, 43, 4028-4038. [CrossRef] [PubMed]

249. Pajares, M.; Jiménez-Moreno, N.; Dias, I.H.; Debelec, B.; Vucetic, M.; Fladmark, K.E.; Basaga, H.; Ribaric, S.; Milisav, I.; Cuadrado, A. Redox control of protein degradation. Redox Biol. 2015, 6, 409-420. [CrossRef] [PubMed]

250. Li, J.; Jia, H.; Wang, J.; Cao, Q.; Wen, Z. Hydrogen sulfide is involved in maintaining ion homeostasis via regulating plasma membrane $\mathrm{Na}^{+} / \mathrm{H}^{+}$antiporter system in the hydrogen peroxide-dependent manner in salt-stress Arabidopsis thaliana root. Protoplasma 2014, 251, 899-912. [CrossRef]

251. Nahar, K.; Hasanuzzaman, M.; Alam, M.M.; Rahman, A.; Suzuki, T.; Fujita, M. Polyamine and nitric oxide crosstalk: Antagonistic effects on cadmium toxicity in mung bean plants through upregulating the metal detoxification, antioxidant defense and methylglyoxal detoxification systems. Ecotoxicol. Environ. Saf. 2016, 126, 245-255. [CrossRef]

252. Gupta, V.; Carroll, K.S. Sulfenic acid chemistry, detection and cellular lifetime. Biochim. Biophys. Acta 2014, 1840, 847-875. [CrossRef]

253. Ono, K.; Akaike, T.; Sawa, T.; Kumagai, Y.; Wink, D.A.; Tantillo, D.J.; Hobbs, A.J.; Nagy, P.; Xian, M.; Lin, J. Redox chemistry and chemical biology of $\mathrm{H}_{2} \mathrm{~S}$, hydropersulfides, and derived species: Implications of their possible biological activity and utility. Free Radic. Biol. Med. 2014, 77, 82-94. [CrossRef]

254. Akaike, T.; Ida, T.; Wei, F.-Y.; Nishida, M.; Kumagai, Y.; Alam, M.M.; Ihara, H.; Sawa, T.; Matsunaga, T.; Kasamatsu, S. Cysteinyl-tRNA synthetase governs cysteine polysulfidation and mitochondrial bioenergetics. Nat. Commun. 2017, 8,1-15. [CrossRef]

255. Mano, J.I.; Biswas, M.; Sugimoto, K. Reactive carbonyl species: A missing link in ROS signaling. Plants 2019, 8, 391. [CrossRef]

256. Yalcinkaya, T.; Uzilday, B.; Ozgur, R.; Turkan, I. The roles of reactive carbonyl species in induction of antioxidant defence and ROS signalling in extreme halophytic model Eutrema parvulum and glycophytic model Arabidopsis thaliana. Environ. Exp. Bot. 2019, 160, 81-91. [CrossRef]

257. Mano, J.I.; Kanameda, S.; Kuramitsu, R.; Matsuura, N.; Yamauchi, Y. Detoxification of reactive carbonyl species by glutathione transferase Tau isozymes. Front. Plant Sci. 2019, 10, 487. [CrossRef] [PubMed]

258. Islam, M.M.; Ye, W.; Matsushima, D.; Rhaman, M.S.; Munemasa, S.; Okuma, E.; Nakamura, Y.; Biswas, M.S.; Mano, J.I.; Murata, Y. Reactive carbonyl species function as signal mediators downstream of $\mathrm{H}_{2} \mathrm{O}_{2}$ production and regulate $\left[\mathrm{Ca}^{2+}\right]$ cyt elevation in ABA signal pathway in Arabidopsis guard cells. Plant Cell Physiol. 2019, 60, 1146-1159. [CrossRef] [PubMed]

259. Kaur, C.; Singla-Pareek, S.L.; Sopory, S.K. Glyoxalase and methylglyoxal as biomarkers for plant stress tolerance. Crit. Rev. Plant Sci. 2014, 33, 429-456. [CrossRef] 
260. Saito, R.; Yamamoto, H.; Makino, A.; Sugimoto, T.; Miyake, C. Methylglyoxal functions as Hill oxidant and stimulates the photoreduction of $\mathrm{O}_{2}$ at photosystem I: A symptom of plant diabetes. Plant Cell Environ. 2011, 34, 1454-1464. [CrossRef]

261. Hao, Q.; Maret, W. Aldehydes release zinc from proteins. A pathway from oxidative stress/lipid peroxidation to cellular functions of zinc. FEBS J. 2006, 273, 4300-4310. [CrossRef]

262. Kiranmai, K.; Lokanadha Rao, G.; Pandurangaiah, M.; Nareshkumar, A.; Amaranatha Reddy, V.; Lokesh, U.; Venkatesh, B.; Anthony Johnson, A.; Sudhakar, C. A novel WRKY transcription factor, MuWRKY3 (Macrotyloma uniflorum Lam. Verdc.) enhances drought stress tolerance in transgenic groundnut (Arachis hypogaea L.) plants. Front. Plant Sci. 2018, 9, 346. [CrossRef]

263. Sun, X.; Wang, P.; Jia, X.; Huo, L.; Che, R.; Ma, F. Improvement of drought tolerance by overexpressing MdATG18a is mediated by modified antioxidant system and activated autophagy in transgenic apple. Plant Biotechnol. J. 2018, 16, 545-557. [CrossRef]

264. Wang, K.; Zhong, M.; Wu, Y.-h.; Bai, Z.-y.; Liang, Q.-y.; Liu, Q.-1.; Pan, Y.-z.; Zhang, L.; Jiang, B.-b.; Jia, Y. Overexpression of a chrysanthemum transcription factor gene $D g N A C 1$ improves the salinity tolerance in chrysanthemum. Plant Cell Rep. 2017, 36, 571-581. [CrossRef]

265. Shafi, A.; Pal, A.K.; Sharma, V.; Kalia, S.; Kumar, S.; Ahuja, P.S.; Singh, A.K. Transgenic potato plants overexpressing SOD and APX exhibit enhanced lignification and starch biosynthesis with improved salt stress tolerance. Plant Mol. Biol. Rep. 2017, 35, 504-518. [CrossRef]

266. Sapara, K.K.; Khedia, J.; Agarwal, P.; Gangapur, D.R.; Agarwal, P.K. SbMYB15 transcription factor mitigates cadmium and nickel stress in transgenic tobacco by limiting uptake and modulating antioxidative defence system. Funct. Plant Biol. 2019, 46, 702-714. [CrossRef] [PubMed]

267. Kumar, A.; Dubey, A.K.; Kumar, V.; Ansari, M.A.; Narayan, S.; Kumar, S.; Pandey, V.; Shirke, P.A.; Pande, V.; Sanyal, I. Over-expression of chickpea glutaredoxin $(\mathrm{CaGrx})$ provides tolerance to heavy metals by reducing metal accumulation and improved physiological and antioxidant defence system. Ecotoxicol. Environ. Saf. 2020, 192, 110252. [CrossRef] [PubMed]

268. Karkute, S.; Krishna, R.; Ansari, W.; Singh, B.; Singh, P.; Singh, M.; Singh, A. Heterologous expression of the AtDREB1A gene in tomato confers tolerance to chilling stress. Biol. Plant. 2019, 63, 268-277. [CrossRef]

269. Che, Y.; Zhang, N.; Zhu, X.; Li, S.; Wang, S.; Si, H. Enhanced tolerance of the transgenic potato plants overexpressing $\mathrm{Cu} / \mathrm{Zn}$ superoxide dismutase to low temperature. Sci. Hortic. 2020, 261, 108949. [CrossRef]

270. Wang, L.; Gao, J.; Zhang, Z.; Liu, W.; Cheng, P.; Mu, W.; Su, T.; Chen, S.; Chen, F.; Jiang, J. Overexpression of CmSOS1 confers waterlogging tolerance in Chrysanthemum. J. Integr. Plant Biol. 2019. [CrossRef] [PubMed]

271. Zhu, D.; Hou, L.; Xiao, P.; Guo, Y.; Deyholos, M.K.; Liu, X. VvWRKY30, a grape WRKY transcription factor, plays a positive regulatory role under salinity stress. Plant Sci. 2019, 280, 132-142. [CrossRef]

272. Zhang, W.; Wang, N.; Yang, J.; Guo, H.; Liu, Z.; Zheng, X.; Li, S.; Xiang, F. The salt-induced transcription factor GmMYB84 confers salinity tolerance in soybean. Plant Sci. 2020, 291, 110326. [CrossRef]

273. Duan, F.; Ding, J.; Lee, D.; Lu, X.; Feng, Y.; Song, W. Overexpression of SoCYP85A1, a spinach cytochrome p450 gene in transgenic tobacco enhances root development and drought stress tolerance. Front. Plant Sci. 2017, 8, 1909. [CrossRef]

274. Xia, Z.; Xu, Z.; Wei, Y.; Wang, M. Overexpression of the maize sulfite oxidase increases sulfate and GSH levels and enhances drought tolerance in transgenic tobacco. Front. Plant Sci. 2018, 9, 298. [CrossRef]

275. Dubey, A.K.; Kumar, N.; Kumar, A.; Ansari, M.A.; Ranjan, R.; Gautam, A.; Sahu, N.; Pandey, V.; Behera, S.K.; Mallick, S. Over-expression of CarMT gene modulates the physiological performance and antioxidant defense system to provide tolerance against drought stress in Arabidopsis thaliana L. Ecotoxicol. Environ. Saf. 2019, 171, 54-65. [CrossRef]

276. Tan, Y.; Wang, L. MpDGK2, a novel diacylglycerol kinase from Malus prunifolia, confers drought stress tolerance in transgenic Arabidopsis. Plant Mol. Biol. Rep. 2020, 1-9. [CrossRef]

277. Kumar, S.; Khare, R.; Trivedi, P.K. Arsenic-responsive high-affinity rice sulphate transporter, OsSultr1;1, provides abiotic stress tolerance under limiting sulphur condition. J. Hazard. Mater. 2019, 373, 753-762. [CrossRef] [PubMed]

278. Li, Q.; Wang, W.; Wang, W.; Zhang, G.; Liu, Y.; Wang, Y.; Wang, W. Wheat F-box protein gene TaFBA1 is involved in plant tolerance to heat stress. Front. Plant Sci. 2018, 9, 521. [CrossRef] 
279. Huo, L.; Sun, X.; Guo, Z.; Jia, X.; Che, R.; Sun, Y.; Zhu, Y.; Wang, P.; Gong, X.; Ma, F. MdATG18a overexpression improves basal thermotolerance in transgenic apple by decreasing damage to chloroplasts. Hortic. Res. 2020, 7, 1-15. [CrossRef]

280. Lv, Y.; Fu, S.; Chen, S.; Zhang, W.; Qi, C. Ethylene response factor BnERF2-like (ERF2. 4) from Brassica napus L. enhances submergence tolerance and alleviates oxidative damage caused by submergence in Arabidopsis thaliana. Crop J. 2016, 4, 199-211. [CrossRef]

281. Phukan, U.J.; Jeena, G.S.; Tripathi, V.; Shukla, R.K. MaRAP2-4, a waterlogging-responsive ERF from Mentha, regulates bidirectional sugar transporter AtSWEET10 to modulate stress response in Arabidopsis. Plant Biotechnol. J. 2018, 16, 221-233. [CrossRef] [PubMed]

282. Luan, H.; Guo, B.; Shen, H.; Pan, Y.; Hong, Y.; Lv, C.; Xu, R. Overexpression of barley transcription factor HvERF2.11 in Arabidopsisenhances plant waterlogging tolerance. Int. J. Mol. Sci. 2020, 21, 1982. [CrossRef] [PubMed]

(C) 2020 by the authors. Licensee MDPI, Basel, Switzerland. This article is an open access article distributed under the terms and conditions of the Creative Commons Attribution (CC BY) license (http://creativecommons.org/licenses/by/4.0/). 